INSTITUTO DE PESQUISAS ENERGÉTICAS E NUCLEARES

Autarquia associada à Universidade de São Paulo

EFEITO DO TRATAMENTO TÉRMICO NA MICROESTRUTURA E NAS

PROPRIEDADES MECÂNICAS DE AÇOS-FERRAMENTA

PARA TRABALHO A FRIO

EDMO SOARES JUNIOR

Dissertação apresentada como parte

dos requisitos para obtenção do Grau de Mestre em Ciências na Área de Tecnologia Nuclear - Materiais.

Orientadora:

Dra. Marina Fuser Pillis

SÃO PAULO

2006 
DEDICATÓRIA

Ao meu pai Edmo Soares.

À minha mãe Olga Grassetti Soares. 


\section{AGRADECIMENTOS}

À minha orientadora Dra Marina F. Pillis.

Ao Instituto de Pesquisas Energéticas e Nucleares (IPEN) e as empresas MAHLE por disporem de material e equipamentos essenciais para a evolução deste trabalho.

Aos professores do IPEN-USP e da POLI-USP pelo incentivo e troca de conhecimentos.

A Hurt Infer por todo suporte nos tratamentos térmicos, em especial ao Engenheiro Cesar Henrique Lopes da Silva por toda atenção e colaboração.

À Universidade Presbiteriana Mackenzie por todo apoio técnico recebido do Prof. Dr. Jan Vatavuk, e dos Engenheiros de Materiais Leonardo Calicchio e Daniel Rodolpho Domingues.

A todos que colaboraram direta ou indiretamente com a execução deste trabalho, em especial ao MSc Renato Panelli (consultor) e aos amigos da MAHLE Ricardo Platzer, Maurilio Reimberg Andrade, Elaine Cristina e toda equipe dos laboratórios.

A toda minha família e amigos, em especial ao meu pai Edmo Soares, a minha mãe Olga Grassetti, aos meus irmãos Elio David e Karina Grassetti e a querida Roberta Bernardo, que constantemente mostram que o conjunto de sinceros sentimentos que titulam de amor é infinitamente mais importante do que toda e qualquer ciência. 


\title{
EFEITO DO TRATAMENTO TÉRMICO NA MICROESTRUTURA E NAS PROPRIEDADES MECÂNICAS DE AÇOS-FERRAMENTA PARA TRABALHO A FRIO
}

Edmo Soares Junior

\begin{abstract}
RESUMO
Os aços-ferramenta têm importante participação no mercado mundial de aços. São usados na indústria metal-mecânica como ferramentas de corte, moldes, punções, matrizes, etc. Devido ao uso de grande responsabilidade, é importante discutir a relação entre microestrutura e propriedades mecânicas, porque é uma prática comum na indústria especificar os tratamentos térmicos com base principalmente na dureza final do material, sem considerar que para um mesmo valor de dureza um aço-ferramenta pode apresentar diferenças nas propriedades mecânicas, dependendo do ciclo de tratamento térmico aplicado. Logo, esta seleção de tratamento térmico é um aspecto tecnológico relevante no desempenho de aços-ferramentas. Os materiais selecionados foram os aços VND, Calmax, VF-800 e Vanadis 10, sendo os três primeiros produzidos por fundição rota convencional e o último produzido por processo de pressão isostática a quente (HIP) - rota sinterizada.O objetivo deste trabalho foi avaliar o tratamento térmico, a microestrutura e as propriedades mecânicas destes quatro açosferramenta para trabalho a frio, para determinar o tratamento térmico capaz de promover a melhor relação dureza-tenacidade. Os resultados mostraram para o aço VND a possibilidade de se trabalhar com nível de dureza um pouco superior ao recomendado pelo fabricante, com sensível melhora nos parâmetros de resistência sem, no entanto, a ocorrência de um decréscimo importante em termos de tenacidade. Para o aço Calmax os resultados mostraram a possibilidade de trabalhar com dureza um pouco inferior à recomendada pelo fabricante, com significativa melhora nos parâmetros de tenacidade, sem a ocorrência de um decréscimo na resistência. Para os aços VF-800 e Vanadis 10 , os resultados obtidos utilizando-se temperatura de revenimento inferior à recomendada pelo fabricante mostraram um ótimo desempenho em todos os ensaios, com particular atenção aos resultados de energia absorvida.
\end{abstract}




\title{
EFFECT OF HEAT TREATMENT ON MICROSTRUCTURE AND MECHANICAL PROPERTIES OF TOOL STEELS FOR COLD WORK APPLICATION
}

\author{
Edmo Soares Junior
}

\begin{abstract}
Tool steels have important participation in the worldwide market of steels. They are used by metal-mechanical industry as cutting tools, molds, punches, dies etc.Due to the use of great responsibility, it is important to discuss the relationship between microstructure and mechanical properties because it is a common practice in industry to specify heat treatments based mainly in the final hardness of the material without considerations about that for the same value of hardness a tool-steel can present differences in mechanical properties, depending on the heat treatment cycle applied. Thus, the selection of the heat treatment is a relevant technological aspect in the performance of tool steels. The materials selected were VND, Calmax, VF800 and Vanadis 10, being the three first produced by hot ingot casting followed by hot working - conventional route, and the last one by hot isostatic pressing (HIP) process - sintering route. The aim of this work was to evaluate the heat treatment, microstructure and mechanical properties of these four tool steels for cold work application in order to determine the heat treatment able to promote the best relationship hardness-toughness. The results have shown for VND steel the possibility of working with hardness slightly higher than that recommended by the manufacturer, with sensible improvement of strength without, however, the occurrence of an important decrease in toughness. For the Calmax steel the results have shown the possibility of working with hardness values slightly lower than that recommended by the manufacturer, with significant improvement in toughness, without the occurrence of a strength decreasing. For the steels VF-800 and Vanadis 10, the results of lower temperature of tempering than the recommended by the manufacturer have indicated good performance in all mechanical tests, with attention to the absorbed energy results.
\end{abstract}




\section{SUMÁRIO}

Página

1 INTRODUÇÃO

2 OBJETIVO 3

3 REVISÃO DA LITERATURA

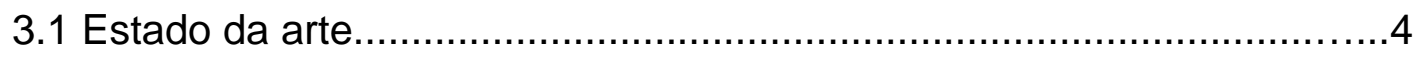

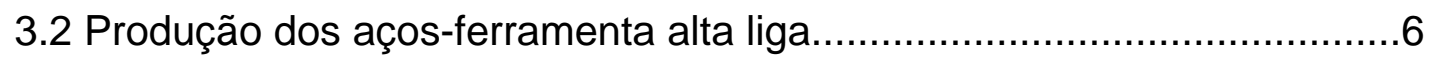

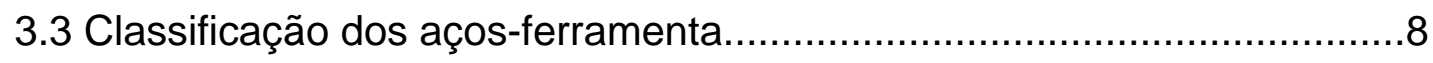

3.4 Aços-ferramenta para trabalho a frio.................................................

3.5 Microestrutura e tratamentos térmicos...............................................14

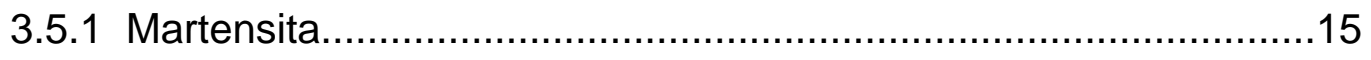

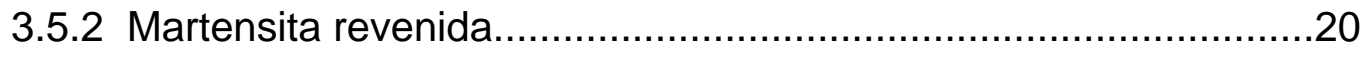

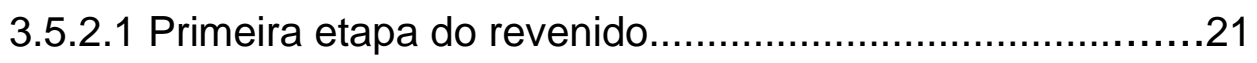

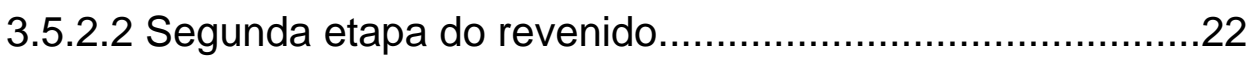

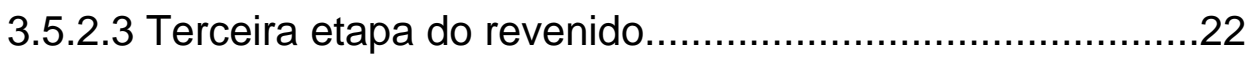

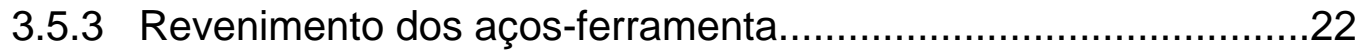

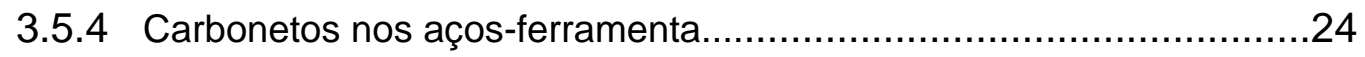

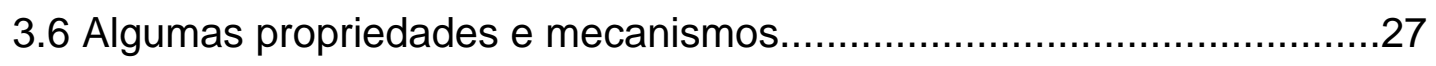

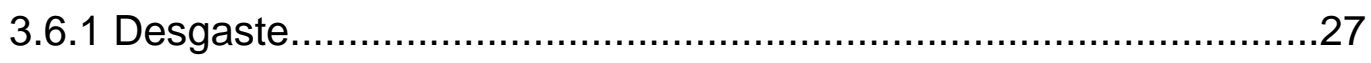

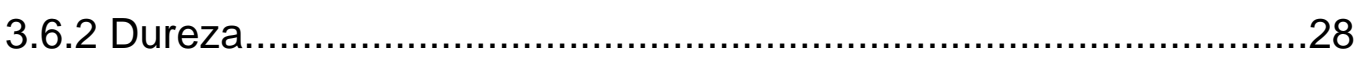

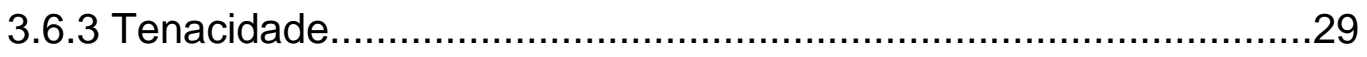

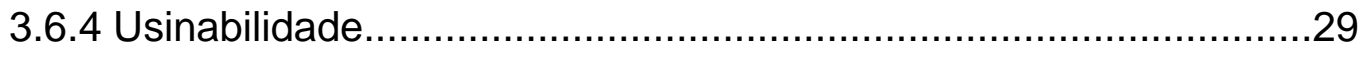

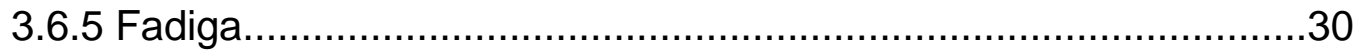

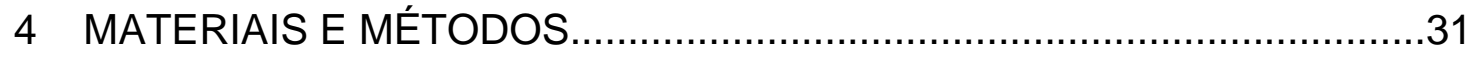

4.1 Seleção dos aços-ferramenta para trabalho a frio................................31

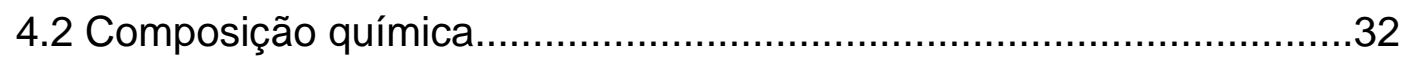

4.3 Reposta ao tratamento térmico indicado pelo fabricante........................33

4.4 Preparação dos corpos de prova para testes mecânicos......................34 


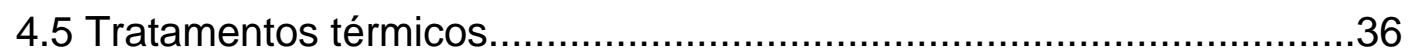

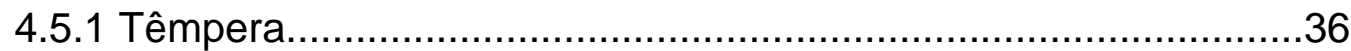

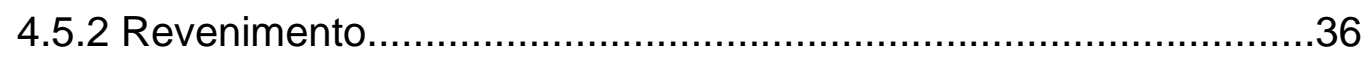

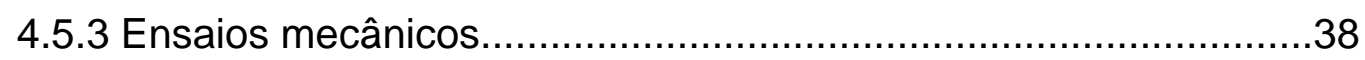

4.5.3.1 Ensaio de Tração.......................................................38

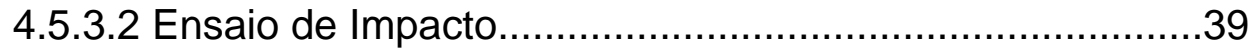

4.5.3.3 Ensaio de Flexão 4-pontos..............................................40

4.5.3.4 Ensaios de dureza........................................................

4.5.4 Caracterização Microestrutural.....................................................

5 RESULTADOS E DISCUSSÃO 42

5.1 Caracterização dos aços no estado como recebido (recozido)..............42

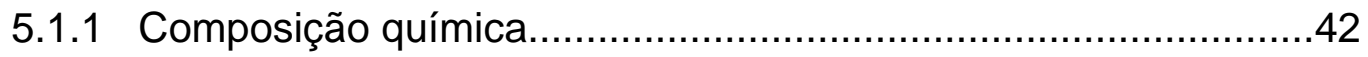

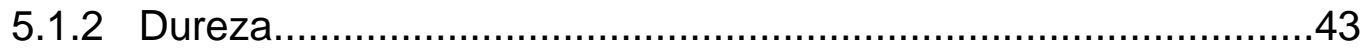

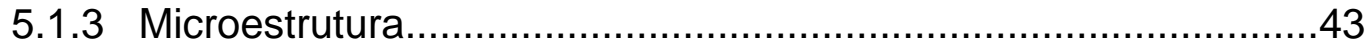

5.2 Caracterização dos aços após tratamentos térmicos.............................49

5.2.1 Aço VND no estado temperado e revenido.................................49

5.2.2 Aço Calmax no estado temperado e revenido...............................55

5.2.3 Aço VF-800 no estado temperado e revenido...............................62

5.2.3 Aço Vanadis 10 no estado temperado e revenido.........................69

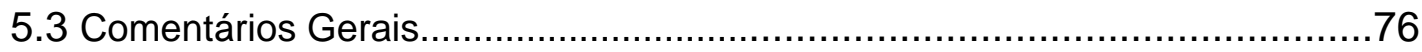

6 CONCLUSÕES $\quad 79$

7 REFERÊNCIAS BIBLIOGRÁFICAS 81 


\section{Lista de Figuras}

Página

Figura 1: Aplicações típicas de aços-ferramenta para trabalho a frio.

Figura 2: Microestrutura do aço ferramenta AISI T15 estado temperado advindo da (a) metalurgia convencional (seta indica carboneto grosseiro);

(b) metalurgia do pó (seta indica carboneto fino).

Figura 3: Esquema de uma microestrutura típica dos aços-ferramenta e seus principais constituintes.

Figura 4: Esquema representando o cisalhamento e a superfície associados à formação da martensita.

Figura 5: Rearranjo atômico (carbono).

Figura 6: Curva representando o $\mathrm{M}_{\mathrm{s}}$ conforme os teores de $\mathrm{C}$ nos aços, bem como o tipo de cristalografia esperada.

Figura 7: Situações de ocorrência de desgaste tipo adesivo.

Figura 8: Situações de ocorrência de desgaste tipo abrasivo.

Figura 9: Área de fratura de um eixo aço carbono.

Figura 10: Curva de revenimento dos aços contidos no presente estudo e do aço AISI D2.

Figura 11: Fluxograma de etapas e ensaios realizados no projeto.

Figura 12: Dimensões do corpo-de-prova para ensaio de tração.

Figura 13: Dimensões do corpo-de-prova para ensaio de flexão 4-pontos. 
Figura 14: Dimensões do corpo-de-prova para ensaio de impacto Charpy Página sem entalhe.

Figura 15: Ilustra o tratamento térmico dos corpos de prova (a) dos materiais utilizados neste estudo e do forno utilizado (b) com resfriamento em banho 38 de sal.

Figura 16: Ilustra o maquinário utilizado para os testes de tração.

Figura 17: Esquema do ensaio de impacto Charpy sem entalhe.

Figura 18: Esquema do dispositivo usado para realização do ensaio de flexão 4-pontos.

Figura 19: Gráfico dos valores de dureza para os aços em estudo - no estado recozido.

Figura 20: Microestrutura do aço VND como recebido. (a) secção longitudinal região de superfície: (b) secção longitudinal região do núcleo; (c) secção transversal região de superfície; (d) secção transversal região de núcleo.

Figura 21: Microestrutura do aço Calmax como recebido. (a) secção longitudinal região de superfície: (b) secção longitudinal região do núcleo; (c) secção transversal região de superfície; (d) secção transversal região de núcleo.

Figura 22: Microestrutura do aço VF-800 como recebido. (a) secção longitudinal região de superfície: (b) secção longitudinal região do núcleo; (c) secção transversal região de superfície; (d) secção transversal região de núcleo. 
Figura 23: Secção transversal região de $1 / 2$ do raio do aço VF-800 como recebido.

Figura 24: Microestrutura do aço Vanadis 10 como recebido. (a) secção longitudinal região de superfície: (b) secção longitudinal região do núcleo; (c) secção transversal região de superfície; (d) secção transversal região de núcleo.

Figura 25: Secção longitudinal região de 1/2 do raio do aço Vanadis 10 como recebido.

Figura 26: Secção transversal região de $1 / 2$ do raio do aço Vanadis 10 como recebido.

Figura 27: Secção transversal do aço VND. Ataque nital 3\%. (a) Somente temperado; (b) Temperado e revenido a $260^{\circ} \mathrm{C}$; (c) Temperado e revenido a 50 $300^{\circ} \mathrm{C}$; (c) Temperado e revenido a $370^{\circ} \mathrm{C}$.

Figura 28: (a) Secção transversal do aço VND somente temperado. Ataque Marble; (b) Secção transversal VND temperado e revenido a $300^{\circ} \mathrm{C}$; (c) EDS de carbonetos; (d) EDS da matriz.

Figura 29: Dureza em função da temperatura de revenimento para o aço VND.

Figura 30: Limite de resistência em função da dureza para o aço VND.

Figura 31: Tenacidade em função da dureza para o aço VND.

Figura 32: Módulo de ruptura em função da dureza para o aço VND. 
Figura 33: Fractografia típica mostrando a superfície de fratura do corpo-deprova do aço VND. Seta branca indicando provável região de inicio de fratura.

Figura 34: Aumento em região da figura anterior, mostrando a região próxima ao centro.

Figura 35: Secções transversais do aço Calmax. (a) somente temperado; (b) temperado e revenido a $200^{\circ} \mathrm{C}$; (c) temperado e revenido a $250^{\circ} \mathrm{C}$; (d) temperado e revenido a $300^{\circ} \mathrm{C}$; (e) temperado e revenido a $350^{\circ} \mathrm{C}$; (f) temperado e revenido a $400^{\circ} \mathrm{C}$; (g) temperado e revenido a $450^{\circ} \mathrm{C}$; (h) 56 temperado e revenido a $500^{\circ} \mathrm{C}$.

Figura 36: (a) Seção transversal Calmax somente temperado. Ataque Marble; (b) Detalhe seção transversal Calmax somente temperado. Marble; (c) EDS carbonetos ricos em cromo possivelmente do tipo $M_{3} C$; (d) EDS da matriz.

Figura 37: (a) Secção transversal do aço Calmax temperado e revenido a $300^{\circ} \mathrm{C}$. Ataque Nital 3\%; (b) aumento em região da figura (a); (c) EDS dos 58 carbonetos; (d) EDS da matriz.

Figura 38: Dureza em função da temperatura de revenimento para o aço Calmax.

Figura 39: Limite de resistência em função da dureza para o aço Calmax.

Figura 40: Tenacidade à fratura em função da dureza para o aço Calmax. 
Figura 41: Módulo de ruptura em função da dureza para o aço Calmax.

Figura 42: Fractografia típica mostrando a superfície de fratura do corpo-deprova do aço calmax.

Figura 43: Aumento em região da figura anterior, próxima à borda. Região de provável início da fratura.

Figura 44: Secções transversais do aço VF-800. (a) somente temperado; (b) temperado e revenido em $300^{\circ} \mathrm{C}$; (c) temperado e revenido em $475^{\circ} \mathrm{C}$; (d) temperado e revenido em $540^{\circ} \mathrm{C}$; (e) temperado e revenido em $550^{\circ} \mathrm{C}$; (f) temperado e revenido em $580^{\circ} \mathrm{C}$.

Figura 45: (a) Secção transversal do aço VF800 somente temperado. Ataque Marble; (b) EDS carbonetos ricos em cromo, possivelmente do tipo $\mathrm{M}_{7} \mathrm{C}_{3}$; (c) EDS carbonetos ricos em molibdênio, possivelmente do tipo $\mathrm{M}_{2} \mathrm{C}$; (d) EDS da matriz.

Figura 46: (a) Secção transversal do VF800 temperado e revenido a $475^{\circ} \mathrm{C}$. Ataque Marble; (b) Detalhe de carbonetos ricos em cromo (c) EDS carbonetos ricos em cromo possivelmente do tipo $\mathrm{M}_{7} \mathrm{C}_{3}$; (d) EDS dos carbonetos ricos em molibdênio, possivelmente do tipo $\mathrm{M}_{2} \mathrm{C}$.

Figura 47: Dureza em função da temperatura de revenimento para o aço VF-800.

Figura 48: Limite de resistência em função da dureza para o aço VF-800.

Figura 49: Tenacidade à fratura em função da dureza para o aço VF-800.

Figura 50: Módulo de ruptura em função da dureza para o aço VF-800. 
Figura 51: VF-800: Fractografia típica mostrando a superfície de fratura do corpo-de-prova. Seta branca indicando provável região de inicio de fratura.

Figura 52: VF-800: Detalhe da figura anterior, mostrando a região próxima à 69 borda. Região de provável início da fratura.

Figura 53: Secção transversal do aço vanadis 10. (a) somente temperado; (b) temperado e revenido a $430^{\circ} \mathrm{C}$; (c) temperado e revenido a $525^{\circ} \mathrm{C}$; (d) 70 temperado e revenido a $550^{\circ} \mathrm{C}$.

Figura 54: (a) Secção transversal do aço Vanadis 10 somente temperado. Ataque Marble; (b) EDS carbonetos (claros) ricos em cromo, possivelmente 71 do tipo $\mathrm{M}_{7} \mathrm{C}_{3}$; (c) EDS carbonetos ricos em vanádio, possivelmente do tipo $\mathrm{M}_{2} \mathrm{C} ;(\mathrm{d})$ EDS da matriz.

Figura 55: (a) Seção transversal do aço Vanadis 10 temperado e revenido a $430^{\circ} \mathrm{C}$. Ataque Nital 3\%; (b) EDS dos carbonetos primários; (c) EDS dos carbonetos secundários; (d) EDS da matriz.

Figura 56: Dureza em função da temperatura de revenimento para o aço Vanadis 10.

Figura 57: Limite de resistência em função da dureza para o aço Vanadis 73 10.

Figura 58: Tenacidade à fratura em função da dureza para o aço Vanadis 10.

Figura 59: Módulo de ruptura em função da dureza para o aço Vanadis 10. 
Figura 60: Vanadis 10: Fractografia típica, mostrando a superfície de fratura do corpo-de-prova.

Figura 61: Vanadis 10: Detalhe da figura anterior, mostrando a região 75 próxima à borda. Região de provável início da fratura. 


\section{Lista de Tabelas}

Página

Tabela 1: Cronologia do desenvolvimento dos aços-ferramenta.

Tabela 2: Classificação básica dos aços-ferramenta

Tabela 3: Composição química dos principais aços-ferramenta para trabalho a frio

Tabela 4: Alguns dos principais aços para trabalho a frio sinterizados

Tabela 5: Aplicações dos aços-ferramenta para trabalho a frio alto $\mathrm{C}$ - alto Cr.

Tabela 6: Principais constituintes microestruturais e propriedades relacionadas.

Tabela 7: Comparação entre o revenido tradicional de um aço baixa liga e de um aço ferramenta.

Tabela 8: Principais carbonetos nos aços-ferramenta.

Tabela 9: Temperatura de formação dos carbonetos durante o revenido.

Tabela 10: Composição química nominal dos aços para trabalho a frio tradicionais (AISI D2 e AISI D6) e dos selecionados para este estudo.

Tabela 11: Condições de têmpera dos aços-ferramenta em estudo.

Tabela 12: Condições de revenimento para o aço VND.

Tabela 13: Condições de revenimento para o aço Calmax. 
Página

Tabela 14: Condições de revenimento para o aço VF-800

Tabela 15: Condições de revenimento para o aço Vanadis 10.

Tabela 16: Composição química dos aços-ferramenta em estudo.

Tabela 17: Valores de dureza obtidos nos aços em estudo - estado 43 recozido.

\section{Lista de Símbolos Especiais}

$\varepsilon$ - Carboneto de estequiometria aproximada $\mathrm{Fe}_{2-4} \mathrm{C}$ e estrutura hexagonal compacta.

$\alpha-\quad$ Estrutura denominada ferrita, cúbica de corpo centrado (CCC).

$\gamma=\quad$ Estrutura denominada austenita, cúbica de face centrada (CFC).

® - $\quad$ Marca registrada. 


\section{INTRODUÇÃO}

Os aços-ferramenta têm uma participação importante no mercado mundial dos aços. São amplamente utilizados pela indústria metal-mecânica como punções, machos, matrizes, ferramentas de corte e outros componentes estruturais. Durante o contacto entre a ferramenta e o material de trabalho, a superfície da ferramenta é submetida a altas tensões, o que pode resultar em micro-trincas e fratura subseqüente. Inclusões e carbonetos, bem como defeitos superficiais, são conhecidos sítios para nucleação de trincas $[1,2]$.

O método convencional para fabricação dos aços-ferramenta é via fusão. Durante a solidificação, os elementos de liga presentes tendem a segregar, formando uma rede de carbonetos grosseiros, levando o lingote a apresentar uma estrutura heterogênea. Com a técnica de metalurgia do pó, o metal líquido se solidifica rapidamente durante o processo de atomização. Posteriormente, o pó é submetido à compactação isostática, e o material obtido é mais homogêneo, a granulação é mais fina e os carbonetos são menores que no processo convencional [3]. Neste aspecto, a metalurgia do pó é considerada o avanço mais significativo para a confecção de aços-ferramenta.

Os aços-ferramenta, de uma maneira geral, são fornecidos pelos fabricantes na condição recozidos, com matriz ferrítica, e carbonetos primários e secundários precipitados. A dureza encontra-se na faixa de $220 \mathrm{HB}$ a $300 \mathrm{HB}$, o que permite fácil conformação e usinagem. Estes aços são utilizados após serem submetidos a uma seqüência de tratamentos térmicos: austenitização, têmpera e revenido, para que adquiram propriedades mecânicas adequadas ao uso. A austenitização consiste em aquecer o aço até a temperatura desejada de solubilização e, na seqüência, resfriá-lo rapidamente (têmpera) para evitar as transformações perlítica e bainítica, obtendo-se, deste modo, uma estrutura martensítica metaestável.

As estruturas martensíticas são frágeis, e o tratamento térmico de revenido se torna fundamental para o resgate parcial de uma estrutura com maior tenacidade. $\mathrm{Na}$ prática, o revenido é um tratamento térmico subcrítico, que consiste em aquecer os aços temperados numa temperatura inferior à eutetóide, promover um patamar, seguido novamente de resfriamento até a temperatura ambiente, por repetidas vezes, se necessário [4,5]. O objetivo do tratamento do revenido é facilitar fenômenos de difusão 
para se alcançar uma estrutura mais estável e menos frágil. Este tratamento é usualmente aplicado nos aços-ferramenta com o intuito de se atingir um balanço entre dureza e tenacidade, dependendo da aplicação final da ferramenta, assim como, em alguns casos, promover o endurecimento secundário. Os elementos microestruturais mais relevantes presentes nos aços-ferramenta, em condição de uso, são a matriz de martensita revenida, com carbonetos que, na maioria dos casos, são coerentes com a matriz [5]. Mesmo com aplicações de grande responsabilidade, há pouca informação disponível a respeito da correlação entre a microestrutura e as propriedades mecânicas. Faltam dados importantes para o projeto de componentes, tais como limite de resistência à tração, módulo de ruptura, tenacidade, fadiga, etc. Além disso, é prática comum na indústria a especificação de tratamentos térmicos baseada exclusivamente na dureza final da peça. Ocorre que, para uma mesma dureza, um aço pode apresentar variações nos limites de resistência e na tenacidade, dependendo do ciclo térmico aplicado. Conseqüentemente, é possível ter-se duas peças fabricadas com o mesmo aço e apresentando a mesma dureza, mas com desempenho em uso completamente diferente. Assim, a seleção do tratamento térmico é um aspecto tecnologicamente relevante na aplicação dos aços-ferramenta.

Estão apresentados nas secções seguintes, alguns aspectos fundamentais de tratamentos térmicos, microestrutura e propriedades mecânicas de aços-ferramenta, levantamento bibliográfico pertinente, procedimento experimental utilizado, discussão e resultados. 


\section{OBJETIVOS}

Este trabalho teve por objetivos:

- Correlacionar a microestrutura e as propriedades mecânicas dos aços-ferramenta para trabalho a frio (VND, Calmax, VF-800, e Vanadis 10) com o tratamento térmico a que foram submetidos, determinando a melhor condição para atingir uma combinação de propriedades mecânicas adequadas ao uso.

- Comparar os resultados obtidos com a prática indicada pelos fabricantes. 


\section{REVISÃO DA LITERATURA}

\subsection{Estado da Arte}

Ferramentas de um modo em geral acompanham cada passo da própria evolução do homem. No mundo moderno, as ferramentas possuem papel fundamental na tecnologia de produção de bens e serviços, apresentando aplicações que vão desde domésticas até a indústria aeroespacial.

Embora os egípcios tenham utilizado ligas de ferro entre 5000 e 6000 anos atrás, a literatura aponta o descobrimento de uma picareta como sendo a primeira ferramenta encontrada em aço temperado, apresentando estrutura típica martensítica, utilizada na Galiléia entre 1100 e 1200 AC [6,7].

A história dos aços-ferramenta está intimamente relacionada à própria evolução dos aços em geral. Os primeiros aços-ferramenta da era moderna eram simples aços carbono contendo teores de carbono de 0,7 a 1,5\%. A partir da metade do século XIX e início do século $X X$, os aços-ferramenta se tornaram materiais ligados, apresentando microestrutura complexa. Em geral os aços-ferramenta são ligas Fe-C com adição de elementos de liga formadores de carbonetos como vanádio, tungstênio, cromo, molibdênio, entre outros. Como o próprio nome sugere, tais aços são aplicados na fabricação de ferramentas de corte, dobramento, moldes, matrizes e qualquer outra ferramenta capaz de transformar um material em uma peça de uso bem definido $[6,8,9]$.

Muitos aços-ferramenta atualmente empregados foram desenvolvidos no início do século XX de forma empírica, como a liga 18\%W-4Cr\%-1\%V, conhecida como AISI T1. Outros dos mais importantes aços-ferramenta aplicados até hoje, já completaram mais de sessenta anos de existência, como o AISI T5 e o AISI M4. Até meados dos anos 70, do ponto de vista tecnológico, apenas pequenas modificações foram notadas para a família de aços-ferramenta, principalmente com referência às novas tecnologias de aciaria, as quais levaram a ajustes nos teores de elementos de liga e reduções nos níveis de inclusões $[4,5,6]$.

Mais recentemente, o mais significativo desenvolvimento foi a introdução da metalurgia do pó (M/P) para fabricação dos aços-ferramenta, possibilitando o surgimento de estruturas isotrópicas e homogêneas, potencializando assim a resistência ao 
desgaste, aumentando a tenacidade destes aços e possibilitando o surgimento de novas ligas com composições químicas mais complexas [5].

A tabela 1 mostra uma listagem cronológica do desenvolvimento dos açosferramenta até o surgimento da M/P [7,8].

Tabela 1: Cronologia do desenvolvimento dos aços-ferramenta $[6,8,9]$.

\begin{tabular}{|c|c|}
\hline DATA & DESENVOLVIMENTO \\
\hline $1200 \mathrm{AC}$ & Primeira ferramenta com estrutura martensítica. - Galiléia \\
\hline 350 & Wootz Steel - Índia \\
\hline 900 & Espadas japonesas \\
\hline 1740 & $\begin{array}{c}\text { Fusão em cadinho de aço Blister. } \\
\text { (Huntsman) }\end{array}$ \\
\hline 1868 & $\begin{array}{l}\text { Primeiro aço ligado aplicado como ferramenta Fe-C-W } \\
\text { (Mushet) }\end{array}$ \\
\hline 1902 & $\begin{array}{c}\text { Aços-ferramenta ligados ao } \mathrm{Mn}, \mathrm{W}, \mathrm{Cr}, \mathrm{Ni} \\
\text { (Otto Thallner) }\end{array}$ \\
\hline 1910 & $\begin{array}{l}\text { Identificação de fases cristalinas complexas (raios X, M.O.) } \\
\text { (Becker) }\end{array}$ \\
\hline 1920 & As ligas específicas para aços-ferramenta chegam a doze \\
\hline 1939 & Surgimento dos aços-ferramenta com alto $\mathrm{C} \mathrm{e} \mathrm{V}$. \\
\hline 1956 & $\begin{array}{l}\text { Estudos com microscopia eletrônica em aços-ferramenta } \\
\text { (Trozzo) }\end{array}$ \\
\hline 1961 & Adição de Co $\rightarrow$ dureza HRC 70 \\
\hline 1970 & Início dos estudos e desenvolvimento da M/P \\
\hline 1985 & Desenvolvimento de novas ligas comerciais por M/P \\
\hline
\end{tabular}

Apesar da origem dos aços-ferramenta estar em parte associada aos experimentos de Hunstsman (1740) e Mushet (1868), as importantes publicações de Thallner e Becker no início do século XX originaram o desenvolvimento científico de ligas especialmente concebidas para aplicação como ferramentas. Tal fato impulsionou o desenvolvimento desta família, que em 1920 apresentava doze ligas específicas para a referida aplicação. Com os crescentes avanços das técnicas de observação microestrutural, aliados à consolidação das técnicas de microscopia eletrônica nos meados do século XX, os aços-ferramenta se firmaram como família importante dentre as ligas Fe-C.

Nos últimos anos, o desenvolvimento dos aços-ferramenta foi direcionado principalmente para a melhoria na produtividade dos processos e para o surgimento de novas vias de produção $[6,8,9]$. 
Embora aços-ferramenta desenvolvidos há várias décadas continuem sendo vastamente aplicados, o surgimento de novas técnicas de fabricação como o processo ESR (electroslag remelting), Osprey e principalmente o HIP (hot isostatic pressure) por metalurgia do pó, possibilitaram o refinamento de estruturas de ligas já sacramentadas pelo mercado $[5,6]$.

\subsection{Produção dos aços-ferramenta alta liga}

As complexas faixas de composição química dos aços-ferramenta objetivam estruturas que possam garantir alta dureza e elevada resistência ao desgaste. Rotas convencionais da metalurgia continuam sendo o principal meio de obtenção dos açosferramenta. A fusão através de forno elétrico a arco (EAF - Electric Arc Furnace) seguido de operações de refino em AOD (Argon Oxygen Decarburization), VOD (Vacuum Oxygen Descarburization) e forno-panela (ladle furnace), constituem os principais processos de aciaria empregados para a obtenção dos aços-ferramenta. Ainda no estado líquido, o aço atinge a composição química desejada, sendo em seguida transferido a uma panela, a qual é levada à secção de lingotamento. Devido à referida complexidade da composição dos aços-ferramenta, o grande volume de lingotamento realizado ocorre por via convencional, apesar dos recentes avanços das tecnologias empregadas em sistemas de lingotamento contínuo como o surgimento dos agitadores eletromagnéticos [4,5].

Durante a solidificação dos aços-ferramenta, a diferença de solubilidade entre o metal líquido e o metal sólido gera um fenômeno conhecido por segregação de soluto no fundido. Assim, conforme o avanço da frente de solidificação, o líquido se torna progressivamente mais rico em soluto. A última região a se solidificar será a de maior concentração de elementos de liga. Como conseqüência, obtém-se uma estrutura com composição química e propriedades físicas variando ao longo de um mesmo lingote. Tal estrutura, no caso dos aços-ferramenta, tem como principais características, carbonetos grosseiros, mal distribuídos, ou seja, regiões apresentando pouca incidência de carbonetos e outras com carbonetos em excesso. Esta microestrutura, também conhecida como "bandeada", resulta em um aço-ferramenta extremamente frágil e com regiões propensas a desgaste prematuro.

No caso dos aços-ferramenta para trabalho a frio, os quais são aplicados em condições críticas de solicitações tribológicas e mecânicas, uma combinação de resistência ao desgaste e tenacidade tornou-se fator preponderante para as aplicações modernas. Embora os tradicionais aços desta classe como o AISI A2, D2 e D6, provenientes de lingotamento convencional, mantenham importante participação no mercado tradicional, as novas exigências quanto a desempenho e produtividade, levaram 
os fabricantes a desenvolverem aços-ferramenta com elevados teores de C, Cr, Mo e V, sendo que algumas destas ligas estariam inviabilizadas de serem produzidas por rotas normalmente utilizadas da metalurgia.

O surgimento de novos processos de obtenção dos aços-ferramenta, iniciado há aproximadamente duas décadas de forma efetiva, apesar das limitações, promoveram um intenso esforço para se projetar novas ligas, ou mesmo introduzir novamente no mercado ligas com decréscimo de consumo. Dentre todos os desenvolvimentos que atingiram diretamente os aços-ferramenta, o surgimento da metalurgia do pó é considerado o mais significativo de todos.

Embora se saiba que os primeiros estudos relacionando M/P com açosferramenta datam do início dos anos 70 , somente se observa o crescimento das ligas sinterizadas no mercado dos aços-ferramenta na ultima década.

Uma vez que os aços-ferramenta de alta liga tendem a apresentar uma microestrutura heterogênea, as técnicas e processos da metalurgia do pó são aplicados à referida família dos aços. Tal fato se deve primeiramente à obtenção de uma estrutura homogênea com carbonetos esferoidizados e de tamanho reduzido, caracterizada pela isotropia. Outro ponto fundamental está na possibilidade de obtenção de ligas com composição de extrema complexidade, difíceis ou até mesmo inviáveis de serem produzidas pelas rotas convencionais da metalurgia.

Nos dias atuais, os aços ferramenta produzidos a partir da M/P, encontram-se disponíveis em barras, lingotes, perfis e na vantajosa modalidade próxima ao dimensional final "near net shape" [10].

A mais aplicada rota para obtenção dos aços-ferramenta por metalurgia do pó é dada pela junção de dois processos. Primeiramente, o processo de atomização por gás GAP (gas atomization process) é responsável pela atomização do metal, dando origem ao pó. O segundo processo denominado HIP (hot isostatic pressing) tem a função de compactar o pó em altas temperaturas e elevadíssimas pressões [5].

Outra forma de se obter o pó de ligas classificadas como aços ferramenta é o processo de atomização por água WAP (water atomization process) que difere do GAP por se utilizar água durante a atomização da liga, o que produz partículas angulares com altos teores de oxigênio, nem sempre desejáveis.

A obtenção de ligas complexas através da metalurgia do pó também se inicia com a liga no estado líquido. No caso do processo GAP, o líquido é vazado através de um reduzido bocal por onde um gás, a elevadas pressões, é lançado contra o fluxo líquido, transformando este em reduzidas gotas.

O processo HIP é responsável por $85 \%$ da produção mundial de aços ferramenta sinterizados [5]. Consiste na compactação do pó obtido, submetendo o mesmo a 
temperaturas da ordem de $1100^{\circ} \mathrm{C}$ e pressões de cerca de $100 \mathrm{MPa}$. Tais condições são suficientes para promover uma consolidação e uma total densificação da peça [6].

\subsection{Classificação dos aços-ferramenta}

De maneira geral pode-se definir "aços-ferramenta" como uma classe de materiais utilizados para transformação de outros materiais. A correta escolha do aço-ferramenta para trabalhar em condições denominadas de "a frio", "a quente", "corte" e outras aplicações é a garantia de que o desempenho esperado será atendido.

A principal e mais difundida classificação dos vários tipos de aço-ferramenta foi desenvolvida pela AISI (American Iron and Steel Institute), organizando os mesmos, baseando-se em pontos fundamentais como elementos de liga, aplicação ou tratamento térmico. A tabela 2 apresenta uma classificação dos aços-ferramenta [5, 6, 11].

Tabela 2: Classificação básica dos aços-ferramenta.

\begin{tabular}{c|c|c}
\hline \multirow{2}{*}{ Grupo } & Características & $\begin{array}{c}\text { Símbolo } \\
\text { AISI }\end{array}$ \\
\hline $\begin{array}{c}\text { Aços para trabalho } \\
\text { a frio }\end{array}$ & Alto C, alto Cr & $\mathrm{D}$ \\
\cline { 2 - 3 } & Endurecido ao ar & $\mathrm{A}$ \\
\cline { 2 - 3 } Aços rápidos & Endurecido ao óleo & $\mathrm{O}$ \\
\cline { 2 - 3 } & Ligado ao W & $\mathrm{T}$ \\
\hline $\begin{array}{c}\text { Aços para trabalho } \\
\text { a quente }\end{array}$ & Ligado ao Mo & $\mathrm{M}$ \\
\hline $\begin{array}{c}\text { Aços-ferramenta } \mathrm{Cr}, \mathrm{W} \text { e Mo } \\
\text { baixa Liga }\end{array}$ & $\mathrm{H}$ \\
\hline $\begin{array}{c}\text { Aços resistentes } \\
\text { ao choque }\end{array}$ & $\begin{array}{c}\text { Médio carbono } \\
\text { (tenacidade) }\end{array}$ & $\mathrm{W}$ \\
\hline $\begin{array}{c}\text { Aços-ferramenta } \\
\text { para moldes }\end{array}$ & $\begin{array}{c}\text { Baixo carbono } \\
\text { (estampabilidade) }\end{array}$ & $\mathrm{S}$ \\
\hline
\end{tabular}

Os aços rápidos são assim denominados em face da capacidade que apresentam de usinar materiais em elevadas velocidades de corte. São aplicados como ferramentas de torno, plaina, brocas, fresas, dentre várias aplicações que envolvem corte, desbaste e acabamento [12]. A principal característica desses aços é a chamada resistência ao revenido, propriedade esta que permite manter inalterada a resistência mecânica mesmo quando aquecido na faixa de temperatura entre 500 e $600^{\circ} \mathrm{C}$, que 
ocorre pelo efeito do atrito quando do corte, usinagem ou acabamento produzido pela ferramenta. Tal fato se explica pelos altos teores de elementos de liga formadores de carboneto, como $\mathrm{W}, \mathrm{Mo}, \mathrm{V}$ e $\mathrm{Cr}$, que possuem afinidade com o carbono nesta faixa de temperatura. Assim, mesmo submetidas a uma faixa de temperatura típica de revenido, as ferramentas de aço rápido apresentam um pico de dureza responsável por manter a qualidade da operação, bem como um incremento da vida útil das mesmas $[6,8,11]$.

Os aços-ferramenta para trabalho a quente, designados como grupo $\mathrm{H}$ na classificação do sistema AISI, são aplicados para o processamento a quente de aços, ferros fundidos e ligas não-ferrosas em geral. Constituem matéria-prima para matrizes de forjamento a quente, facas de tesouras para corte a quente, molde de extrusão a quente, entre outras.

Os aços-ferramenta designados pelos grupos $\mathrm{W}, \mathrm{S}$ e $\mathrm{P}$, também denominados aços-ferramenta baixa liga, apresentam moderados teores de carbono e reduzidos teores de elementos de liga. Este grupo de aços-ferramenta apresenta menor custo, e são utilizados em aplicações de média intensidade ou bem específicas.

\subsection{Aços-ferramenta para trabalho a frio}

Como o próprio nome indica, tal família se aplica na conformação a frio de peças e componentes em aços, ferros fundidos e materiais não ferrosos. Destaca-se na fabricação de ferramentas para dobramento, conformação, estampagens, extrusão, além de punções, matrizes de perfis, laminadores de rosca e ferramentas para calibração $[5,6$, 13]. A figura 1 mostra aplicações típicas de aços-ferramenta para trabalho a frio.

Os aços-ferramenta para trabalho a frio normalmente não apresentam elementos de liga em teores suficientes que possam promover o endurecimento secundário, evitando assim a queda das propriedades mecânicas quando expostos a temperaturas superiores a $250^{\circ} \mathrm{C}$. Exceção feita para aços alto $\mathrm{C}$ - alto $\mathrm{Cr}$. 


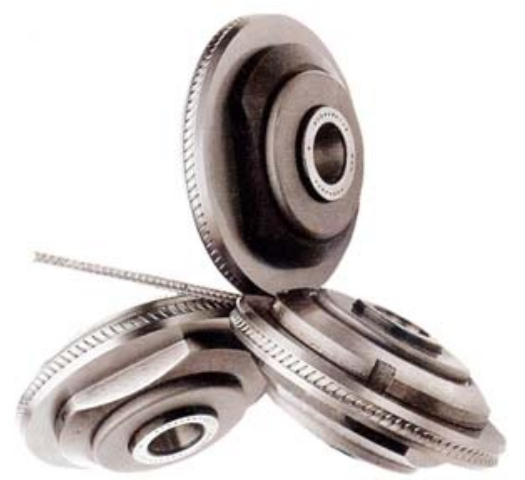

(a)

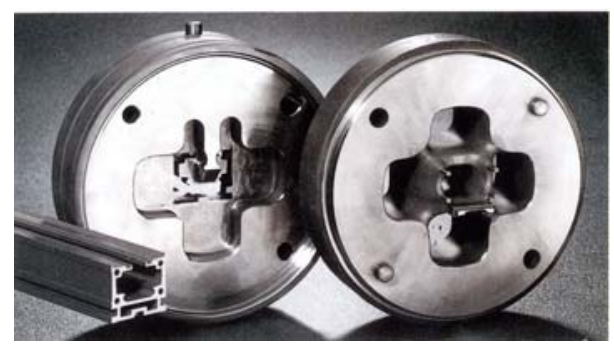

(b)

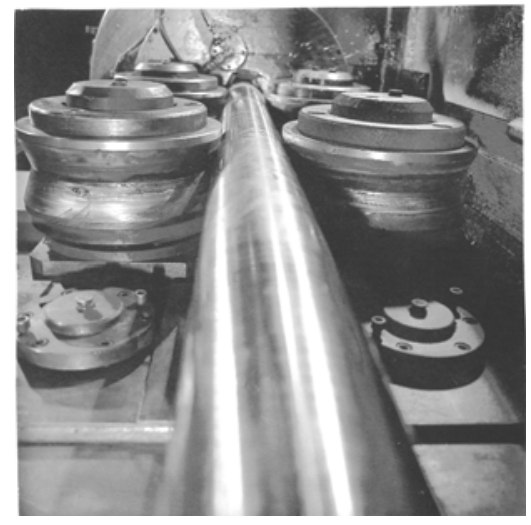

(c)

Figura 1: Aplicações típicas de aços-ferramenta para trabalho a frio [10].

(a) Ferramental de calibração e acabamento de vergalhões; (b) Molde de extrusão para perfis de alumínio; (c) Ferramentas de conformação para tubos em aços inoxidáveis.

Como na maioria das famílias dos aços-ferramenta ligados, a estrutura dos açosferramenta para trabalho a frio consiste em uma matriz de martensita revenida contendo dispersão de carbonetos complexos. Pelas próprias aplicações, os aços-ferramenta para trabalho a frio apresentam alta resistência ao desgaste, alta dureza e estabilidade dimensional. Como no caso dos demais aços desta classe, embora as propriedades tribológicas sejam as mais evidentes nos estudos dos aços-ferramenta para trabalho a frio, as propriedades mecânicas se apresentam como fator relevante para estes materiais, uma vez que tais aços ficam sujeitos a importantes solicitações mecânicas, estáticas e dinâmicas.

Os aços-ferramenta para trabalho a frio se subdividem em três classes distintas denominadas D, A e O. Todas as classes têm em comum altos teores de carbono, que potencializam os valores de dureza, aumentando a resistência ao desgaste. O que as difere são os elementos de liga, que afetam a quantidade e a distribuição dos carbonetos na matriz [12]. 
$\mathrm{Na}$ tabela 3 estão apresentados os principais aços-ferramenta para trabalho a frio e suas respectivas composições químicas [5,6,13].

Tabela 3: Composição química dos principais aços-ferramenta para trabalho a frio.

\begin{tabular}{|c|c|c|c|c|c|c|c|c|c|}
\hline \multirow{2}{*}{$\begin{array}{c}\text { Designação } \\
\text { AISI }\end{array}$} & \multicolumn{9}{|c|}{ Composição Química (\% em peso) } \\
\hline & C & $\mathrm{Mn}$ & $\mathrm{Si}$ & $\mathrm{Cr}$ & $\mathrm{Ni}$ & Mo & W & $\mathrm{V}$ & Co \\
\hline \multicolumn{10}{|c|}{ Aços-ferramenta para trabalho a frio temperáveis ao ar } \\
\hline A2 & $\begin{array}{c}0,95- \\
1,05\end{array}$ & $\begin{array}{l}\text { 1,00 } \\
\text { máx }\end{array}$ & $\begin{array}{l}\text { 0,50 } \\
\text { máx }\end{array}$ & $4,75-5,50$ & $\begin{array}{l}0,30 \\
\text { máx }\end{array}$ & $\begin{array}{c}0,90- \\
1,40\end{array}$ & - & $\begin{array}{l}0,15- \\
0,50\end{array}$ & - \\
\hline A3 & $\begin{array}{c}1,20- \\
1,30\end{array}$ & $\begin{array}{c}0,40- \\
0,60\end{array}$ & $\begin{array}{l}0,50 \\
\text { máx }\end{array}$ & $4,75-5,50$ & $\begin{array}{l}0,30 \\
\text { máx }\end{array}$ & $\begin{array}{l}0,90- \\
1,40\end{array}$ & - & $\begin{array}{c}0,80- \\
1,40\end{array}$ & - \\
\hline A4 & $\begin{array}{c}0,95- \\
1,05\end{array}$ & $\begin{array}{l}1,80- \\
2,20\end{array}$ & $\begin{array}{l}0,50 \\
\text { máx }\end{array}$ & $0,90-2,20$ & $\begin{array}{l}0,30 \\
\text { máx }\end{array}$ & $\begin{array}{l}0,90- \\
1,40\end{array}$ & - & - & - \\
\hline A6 & $\begin{array}{c}0,65- \\
0,75 \\
\end{array}$ & $\begin{array}{l}1,80- \\
2,50 \\
\end{array}$ & $\begin{array}{l}0,50 \\
\text { máx }\end{array}$ & $0,90-1,20$ & $\begin{array}{l}0,30 \\
\text { máx }\end{array}$ & $\begin{array}{c}0,90- \\
1,40\end{array}$ & - & - & - \\
\hline A7 & $\begin{array}{l}2,00- \\
2,85\end{array}$ & $\begin{array}{l}\text { 0,80 } \\
\text { máx }\end{array}$ & $\begin{array}{l}0,50 \\
\text { máx }\end{array}$ & $5,00-5,75$ & $\begin{array}{l}0,30 \\
\text { máx }\end{array}$ & $\begin{array}{l}0,90- \\
1,40\end{array}$ & $\begin{array}{l}0,50- \\
1,50\end{array}$ & $\begin{array}{l}3,90- \\
5,15\end{array}$ & - \\
\hline A8 & $\begin{array}{c}0,50- \\
0,60\end{array}$ & $\begin{array}{l}0,50 \\
\text { máx }\end{array}$ & $\begin{array}{c}0,75- \\
1,10\end{array}$ & $4,75-5,50$ & $\begin{array}{l}0,30 \\
\text { máx }\end{array}$ & $\begin{array}{l}1,15- \\
1,65\end{array}$ & $\begin{array}{l}1,00- \\
1,50\end{array}$ & - & - \\
\hline A9 & $\begin{array}{c}0,45- \\
0,55\end{array}$ & $\begin{array}{l}0,50 \\
\text { máx }\end{array}$ & $\begin{array}{c}0,95- \\
1,15\end{array}$ & $4,75-5,50$ & $\begin{array}{c}1,25- \\
1,75 \\
\end{array}$ & $\begin{array}{l}1,30- \\
1,80\end{array}$ & - & $\begin{array}{c}0,80- \\
1,40\end{array}$ & - \\
\hline A10 & $\begin{array}{l}1,25- \\
1,50^{(\mathrm{c})}\end{array}$ & $\begin{array}{l}1,60- \\
2,10\end{array}$ & $\begin{array}{l}1,00- \\
1,50\end{array}$ & - & $\begin{array}{l}1,55- \\
2,05\end{array}$ & $\begin{array}{l}1,25- \\
1,75\end{array}$ & - & - & - \\
\hline \multicolumn{10}{|c|}{ Aços-ferramenta para trabalho a frio alto carbono e alto cromo } \\
\hline D2 & $\begin{array}{c}1,40- \\
1,60\end{array}$ & $\begin{array}{l}0,60 \\
\text { máx }\end{array}$ & $\begin{array}{l}0,60 \\
\text { máx }\end{array}$ & $\begin{array}{c}11,00- \\
13,00 \\
\end{array}$ & $\begin{array}{l}0,30 \\
\text { máx }\end{array}$ & $\begin{array}{c}0,70- \\
1,20 \\
\end{array}$ & - & $\begin{array}{l}1,10 \\
\text { máx }\end{array}$ & - \\
\hline D4 & $\begin{array}{c}2,05- \\
2,40\end{array}$ & $\begin{array}{l}0,60 \\
\text { máx }\end{array}$ & $\begin{array}{l}0,60 \\
\text { máx }\end{array}$ & $\begin{array}{l}11,00- \\
13,00\end{array}$ & $\begin{array}{l}0,30 \\
\text { máx }\end{array}$ & $\begin{array}{c}0,70- \\
1,20\end{array}$ & - & $\begin{array}{l}1,10 \\
\text { máx }\end{array}$ & - \\
\hline D5 & $\begin{array}{c}1,40- \\
1,60 \\
\end{array}$ & $\begin{array}{l}0,60 \\
\text { máx }\end{array}$ & $\begin{array}{l}0,60 \\
\text { máx }\end{array}$ & $\begin{array}{l}11,00- \\
13,00 \\
\end{array}$ & $\begin{array}{l}0,30 \\
\text { máx }\end{array}$ & $\begin{array}{c}0,70- \\
1,20 \\
\end{array}$ & - & $\begin{array}{l}1,10 \\
\text { máx }\end{array}$ & $\begin{array}{l}2,50- \\
3,50 \\
\end{array}$ \\
\hline D6 & $\begin{array}{l}2,00- \\
2,35\end{array}$ & $\begin{array}{l}0,60 \\
\text { máx }\end{array}$ & $\begin{array}{l}0,60 \\
\text { máx }\end{array}$ & $\begin{array}{l}11,00- \\
13,50\end{array}$ & $\begin{array}{l}0,30 \\
\text { máx }\end{array}$ & - & $\begin{array}{l}\text { 1,0 } \\
\text { máx }\end{array}$ & $\begin{array}{l}\text { 1,00 } \\
\text { máx }\end{array}$ & - \\
\hline D7 & $\begin{array}{l}2,15- \\
2,50 \\
\end{array}$ & $\begin{array}{l}0,60 \\
\text { máx }\end{array}$ & $\begin{array}{l}0,60 \\
\text { máx }\end{array}$ & $\begin{array}{c}11,50- \\
13,50 \\
\end{array}$ & $\begin{array}{l}0,30 \\
\text { máx }\end{array}$ & $\begin{array}{c}0,70- \\
1,20 \\
\end{array}$ & - & $\begin{array}{l}3,80- \\
4,40 \\
\end{array}$ & - \\
\hline \multicolumn{10}{|c|}{ Aços-ferramenta para trabalho a frio temperáveis em óleo } \\
\hline $\mathrm{O} 1$ & $\begin{array}{c}0,85- \\
1,00 \\
\end{array}$ & $\begin{array}{c}1,00- \\
1,40 \\
\end{array}$ & $\begin{array}{l}0,50 \\
\text { máx }\end{array}$ & $0,40-0,60$ & $\begin{array}{l}0,30 \\
\text { máx }\end{array}$ & - & $\begin{array}{l}0,40- \\
0,60\end{array}$ & $\begin{array}{l}0,30 \\
\text { máx }\end{array}$ & - \\
\hline $\mathrm{O} 2$ & $\begin{array}{c}0,85- \\
0,95\end{array}$ & $\begin{array}{r}1,40- \\
1,80 \\
\end{array}$ & $\begin{array}{l}0,50 \\
\text { máx }\end{array}$ & 0,50 máx & $\begin{array}{l}0,30 \\
\text { máx }\end{array}$ & $\begin{array}{l}0,30 \\
\text { máx }\end{array}$ & - & $\begin{array}{l}0,30 \\
\text { máx }\end{array}$ & - \\
\hline O6 & $\begin{array}{c}1,25- \\
1,55\end{array}$ & $\begin{array}{c}0,30- \\
1,10 \\
\end{array}$ & $\begin{array}{c}0,55- \\
1,50 \\
\end{array}$ & 0,30 máx & $\begin{array}{l}0,30 \\
\text { máx }\end{array}$ & $\begin{array}{l}0,30 \\
\text { máx }\end{array}$ & - & - & - \\
\hline $\mathrm{O} 7$ & $\begin{array}{c}1,10- \\
1,30\end{array}$ & $\begin{array}{l}1,00 \\
\text { máx }\end{array}$ & $\begin{array}{l}1,00 \\
\text { máx }\end{array}$ & $0,35-0,85$ & $\begin{array}{l}0,30 \\
\text { máx }\end{array}$ & $\begin{array}{l}0,30 \\
\text { máx }\end{array}$ & $\begin{array}{l}1,00- \\
2,00 \\
\end{array}$ & $\begin{array}{l}0,40 \\
\text { máx }\end{array}$ & - \\
\hline
\end{tabular}


Observa-se que os aços-ferramenta para trabalho a frio da classe $A$, também denominados "temperáveis ao ar", são caracterizados pelos altos teores de $\mathrm{C}, \mathrm{Mn}$, médios teores de $\mathrm{Cr}$ e moderados teores de outros elementos de liga, com exceção do AISI A7. O resultado após tratamento térmico de têmpera e revenido é uma estrutura martensítica com fina dispersão de carbonetos. Esta classe de aços é aplicada em facas de cisalhamento, punções de corte, matrizes para conformação de moedas e outras semelhantes. Pelo fato de serem temperáveis ao ar, possuem a vantagem de minimizar os riscos ou tendência a trincas, assim como tendem a apresentar baixos valores de distorção durante o endurecimento, garantindo estabilidade dimensional, importante propriedade, por exemplo, quando usados como matrizes. O AISI A7 tem aplicação específica na extrusão de materiais de elevada dureza como materiais cerâmicos [5].

Os aços-ferramenta da classe $\mathrm{O}$, também conhecidos como "temperáveis em óleo", possuem altos teores de C e moderados teores de elementos de liga, suficientes para promover boa profundidade de endurecimento pela têmpera em óleo. Difere-se dos demais aços-ferramenta para trabalho a frio devido à baixa resistência ao revenido. As aplicações dos aços do grupo O incluem matrizes e punções para corte, conformação e calibradores para metais não ferrosos $[5,6,13]$.

Os aços-ferramenta alto $\mathrm{C}$ - alto $\mathrm{Cr}$ foram desenvolvidos durante a Primeira Guerra Mundial, com o objetivo de substituir os aços rápidos. Os valores de dureza a quente obtidos na época revelaram-se insuficientes para a referida substituição, tendo sido notado, porém, que a presença de carbonetos em grande quantidade na matriz martensítica revenida aumentava consideravelmente a resistência ao desgaste $[5,6,9]$. Os teores elevados de $\mathrm{C}$ e $\mathrm{Cr}$, além da presença de outros elementos de liga formadores de carbonetos, como o $\mathrm{V}$, promovem uma estrutura com considerável fração volumétrica de carbonetos, responsável diretamente pela alta resistência aos mecanismos de desgaste [6,12]. Por outro lado, os aços-ferramenta para trabalho a frio, devido à forte presença de carbonetos, tendem a apresentar susceptibilidade à falhas catastróficas, devido à sua fragilidade.

O $\mathrm{Cr}$ é o principal elemento de liga presente nos aços da série $D$, com concentração nominal na ordem de $12,5 \%$ em peso. Este teor de $\mathrm{Cr}$ não é suficiente para a formação de um filme passivo estável, como nos aços inoxidáveis, uma vez que um grande percentual deste elemento se encontra na forma de carbonetos, tanto em estado recozido, como temperado e revenido [5].

Embora tais aços apresentem uma série de propriedades importantes para uma ferramenta, o processo de solidificação causa considerável segregação dos elementos de liga, fato que se constitui em desvantagem pela anisotropia gerada. 
$\mathrm{Na}$ tabela 4 estão apresentados alguns dos principais aços-ferramenta para trabalho a frio, produzidos por M/P.

Tabela 4: Alguns dos principais aços para trabalho a frio sinterizados $[15,16,17,18]$.

\begin{tabular}{c|c|c|c|c|c|}
\cline { 3 - 5 } & \multicolumn{4}{c|}{ Composição Química (\% peso) } \\
\hline Fabricante & Nome comercial & C & Cr & Mo & V \\
\hline Böhler & K 190 & 2,30 & 12,50 & 1,10 & 4,00 \\
\hline Crucible & CPM 10V & 2,45 & 5,25 & 1,30 & 9,75 \\
\hline \multirow{2}{*}{ Uddeholm } & Vanadis 10 & 2,90 & 8,00 & 1,50 & 9,80 \\
\cline { 2 - 6 } & ASP 23 & 1,30 & 4,20 & 5,00 & 3,10 \\
\hline
\end{tabular}

Observa-se na tabela 4 que a M/P proporcionou o surgimento de ligas com elevados teores de carbono e elementos formadores de carbonetos, ligas estas inviáveis de produção por metalurgia convencional.

Na figura 2 é mostrada uma comparação entre microestruturas resultantes da metalurgia convencional (a) e da metalurgia do pó (b), para um mesmo aço-ferramenta temperado [19].

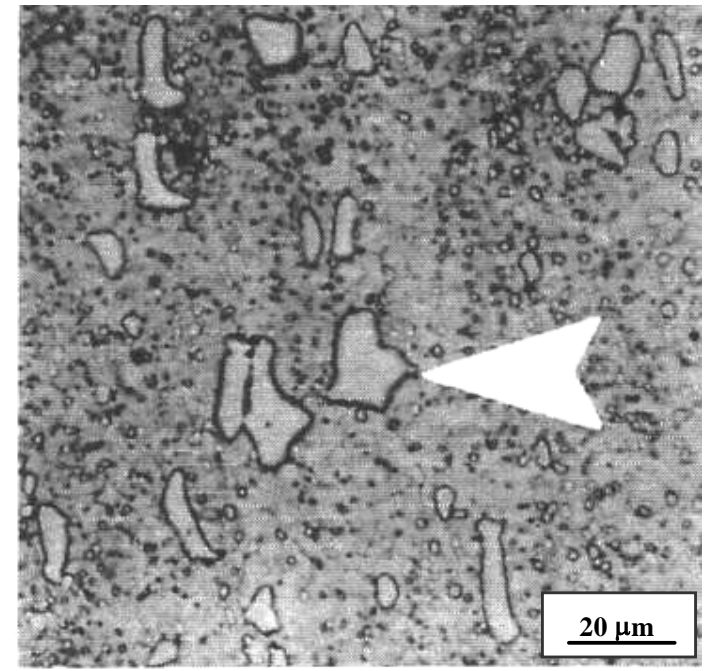

(a)

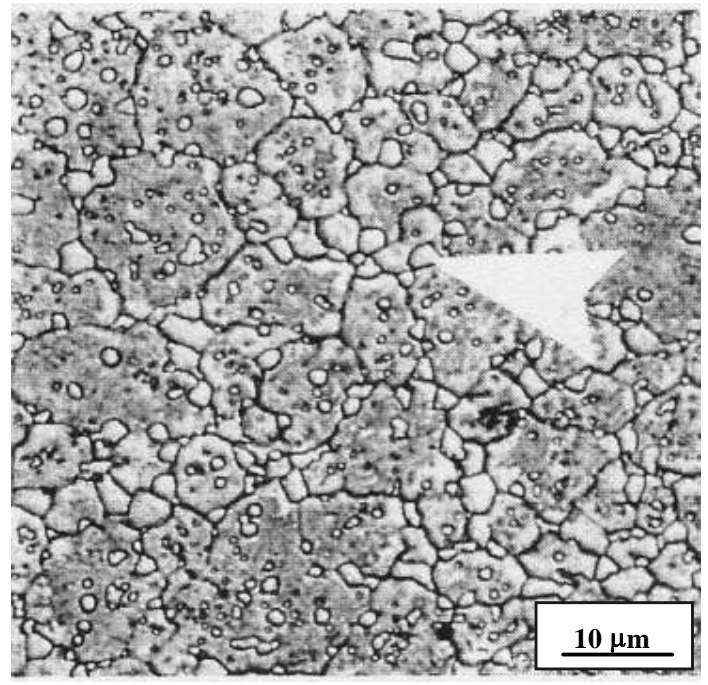

(b)

Figura 2: Microestrutura do aço ferramenta AISI T15 estado temperado advindo da (a) metalurgia convencional (seta indica carboneto grosseiro); (b) metalurgia do pó (seta indica carboneto fino) [19]. Observado em microscópio óptico.

$\mathrm{Na}$ figura 2 observa-se que o aço produzido a partir das técnicas e processo da metalurgia do pó, figura $2 b$ não apresenta uma microestrutura caracterizada por estrias ou bandeamento, mostrando tamanho, distribuição e morfologia homogênea dos carbonetos. Tais características são responsáveis pelo incremento da resistência ao desgaste, à capacidade de corte, a tenacidade, além de reduzir distorções típicas durante os tratamentos térmicos [19]. 
Tabela 5: Aplicações dos aços-ferramenta para trabalho a frio alto C - alto Cr.

\begin{tabular}{c|c|c}
\hline Matrizes & Roletes & Ferramentas \\
\hline & & Punções \\
Estampagem & & Repuxo \\
Corte & Conformação & Brunimento \\
Laminação & Dobramento & Calibradores \\
Dobradeiras & Aperto de solda & Acabamento \\
Extrusão & Guias de chapas & Cutelaria \\
Perfiladeiras & & Mandriladores \\
Rebarbadeiras & & Desbastadores \\
& & \\
\hline
\end{tabular}

Os aços para trabalho a frio, alto $\mathrm{C}$ - alto $\mathrm{Cr}$, apresentam aplicações variadas como mostra a tabela $5[5,6,16,20]$.

\subsection{Microestrutura e tratamentos térmicos}

Os aços-ferramenta, de uma maneira geral, são fornecidos pelos fabricantes na condição recozido e aplicados após tratamento de têmpera e revenido $[11,15,16]$. O fornecimento dos aços-ferramenta na condição recozido (dureza na faixa de 220 a 300 HB) se justifica pela facilidade de se conformar e usinar os mesmos neste estado. A aplicação dos aços-ferramenta após a seqüência de tratamentos de austenitização, têmpera e revenido se baseia na necessidade destes materiais resistirem aos fenômenos de desgaste, presentes nas operações envolvendo fabricação de ferramentas, aliando dureza e tenacidade.

Os mais relevantes elementos microestruturais, presentes nos aços-ferramenta são a matriz metálica, os finos precipitados nela presente e as partículas duras, também envolvidas pela matriz.

A matriz é responsável pela maior fração volumétrica da microestrutura, sendo esta normalmente de martensita revenida. Já os finos precipitados apresentam tamanho máximo de $50 \mathrm{~nm}$ e na maioria dos casos são coerentes com a matriz[5], destacando-se os carbonetos de endurecimento secundário e fases intermetálicas. As chamadas partículas duras apresentam tamanho variando entre 0,1 a $100 \mu \mathrm{m}$, sendo diretamente responsáveis pela resistência ao desgaste e pela queda nas propriedades como ductilidade e tenacidade dos aços-ferramenta [5,6]. Os carbonetos $M C, M_{2} C, M_{6} C$ e $M_{7} C_{3}$ são os exemplos de partículas duras, onde "M" representa um elemento de liga metálica. 
Na figura 3 são mostrados, de forma esquemática, os principais elementos microestruturais presentes nos aços-ferramenta temperados e revenidos.

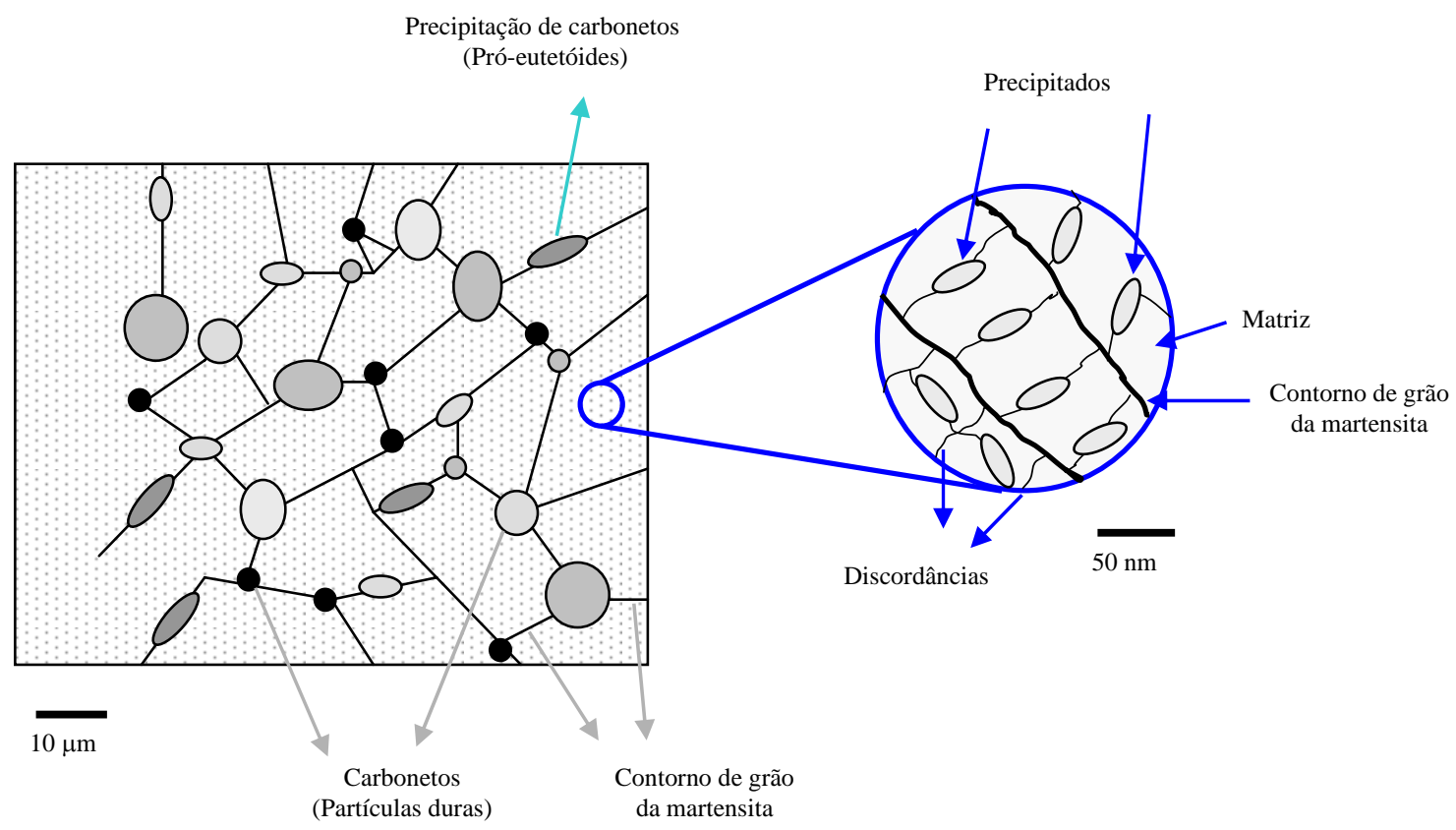

Figura 3: Esquema de uma microestrutura típica dos aços-ferramenta e seus principais constituintes [5, 14, 22].

Na tabela 6 está apresentada uma relação entre os principais constituintes da microestrutura dos aços-ferramenta, figura 3, e suas respectivas propriedades:

Tabela 6: Principais constituintes microestruturais e propriedades relacionadas.

\begin{tabular}{c|l}
\hline Constituinte & \multicolumn{1}{c}{ Propriedades Relacionadas } \\
\hline Matriz metálica & - Tenacidade \\
(martensita revenida) & $\begin{array}{l}\text { - Dureza } \\
\text { - Fonte de C para endurecimento secundário } \\
\text { - Fixar e estabilizar precipitados duros }\end{array}$ \\
\hline Precipitados finos e & - Dureza \\
discordâncias & - Resistência ao desgaste \\
\hline Partículas duras e & - Resistência ao revenido \\
\hline precipitados pró-eutetóides & - Rureza \\
\hline
\end{tabular}

\subsubsection{Martensita}

No caso particular dos aços, a martensita é o produto do resfriamento rápido da austenita, caracterizando a transformação de fase pela não presença da difusão atômica. O resfriamento rápido é necessário para justamente evitar a decomposição da austenita 
por processo difusional, formando produtos como a ferrita e a perlita [5]. Isto significa que sob determinadas taxas de resfriamento, os átomos de carbono podem se difundir fora da estrutura austenítica (cúbica de face centrada) quando esta lentamente se transforma em ferrita (cúbica de corpo centrada). Esta transformação da austenita para ferrita ocorre através do processo de nucleação e crescimento, e depende do tempo. Com um significativo aumento na taxa de resfriamento, o carbono não tem tempo suficiente para se difundir, embora átomos de ferro tenham se movimentado. A estrutura resultante, neste caso, não se transforma em cúbica de corpo centrada, uma vez que o carbono fica "aprisionado". A estrutura resultante é chamada martensita, é supersaturada em carbono, e responsável pela alta resistência mecânica, associada à alta dureza e resistência ao desgaste. Tais características são atribuídas à mencionada estrutura supersaturada em carbono $[6,9,14,23]$.

A martensita se forma por mecanismo de cisalhamento representado na figura 4, a qual traz os aspectos mais relevantes desta transformação [6,9].

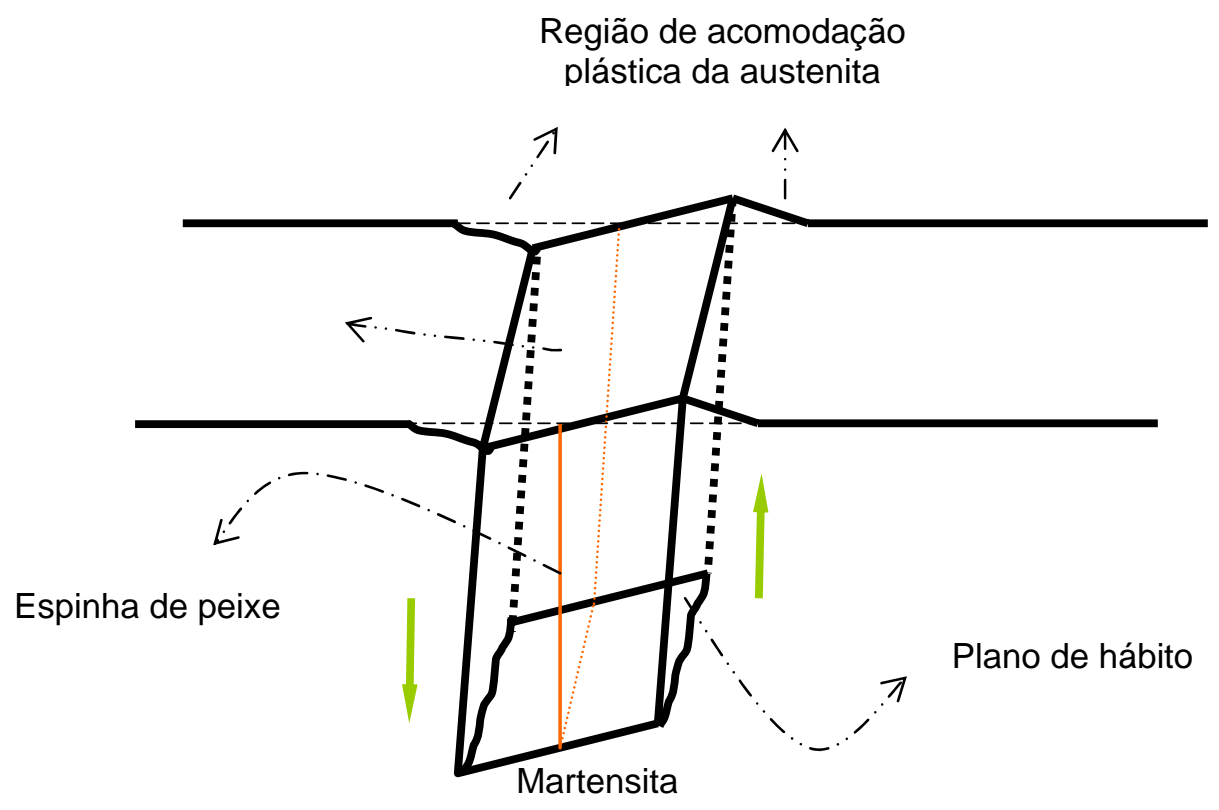

Figura 4: Esquema representando o cisalhamento e a superfície associados à formação da martensita [14].

As setas verticais da figura 4 indicam a direção do cisalhamento no plano que a transformação se iniciou. O cisalhamento resulta numa rotação do plano horizontal original da fase austenítica precursora, característica importante da transformação martensítica. Os planos cristalográficos preferenciais da austenita, que variam de acordo com a composição química do aço, são aqueles onde os cristais de martensita se 
formam, chamados de planos de hábito, um deles representado na figura 4. Outra característica importante representada nessa figura é a chamada "espinha de peixe", considerada como o plano de início da formação de uma placa de martensita. Nos aços, a martensita é derivada da austenita, que apresenta estrutura cúbica de face centrada (CFC). A martensita por sua vez pode se apresentar cúbica de corpo centrada (CCC), hexagonal compacta (HC) ou tetragonal de corpo centrado (TCC).

A maioria dos aços médio e alto carbono, como os aços-ferramenta, formam martensita com estrutura tetragonal de corpo centrado (TCC), uma forma distorcida da estrutura cúbica de corpo centrado (CCC). Tal fato se dá porque os átomos de carbono nestes aços ocupam apenas uma das três possíveis posições intersticiais do octaedro. A tetragonalidade, medida pela relação entre os eixos a e c, aumenta com o teor de carbono [23,24,25]. A figura 5 mostra arranjos típicos da ferrita, da martensita e as possíveis posições para os átomos de carbono na célula unitária.

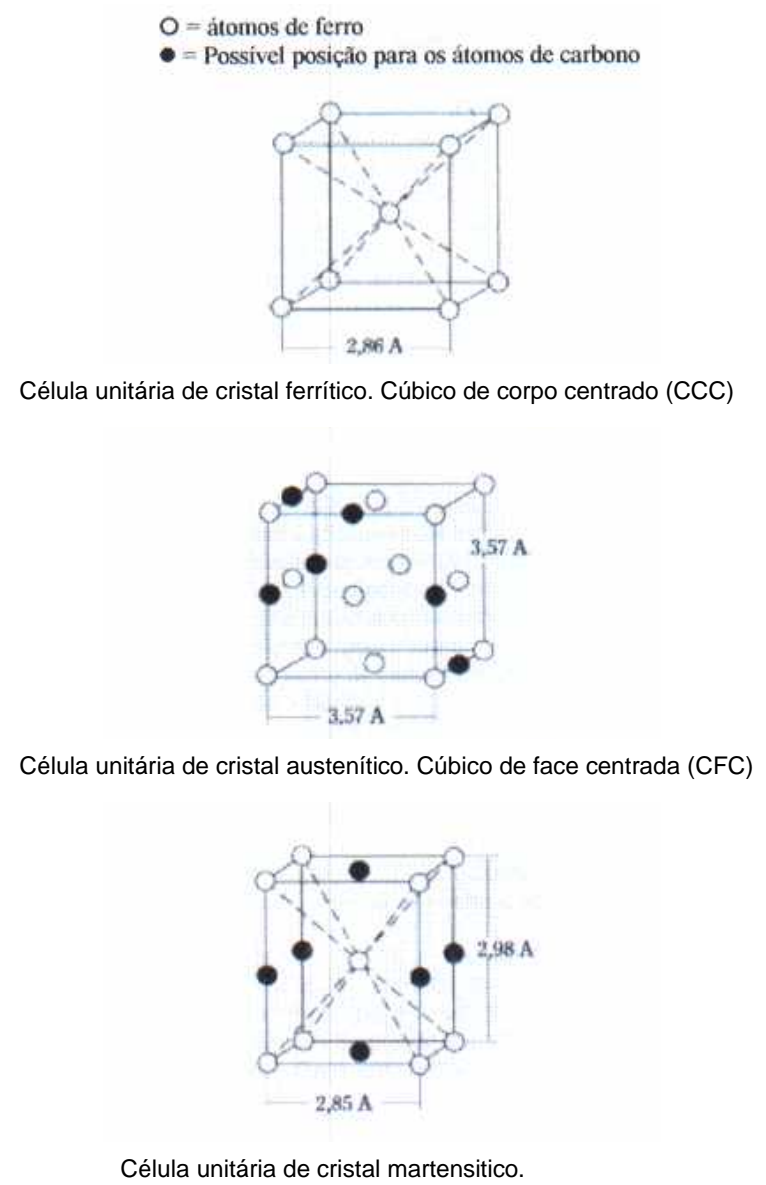

Figura 5: Rearranjo atômico (carbono) [25]. 
O entendimento da estrutura martensítica dos metais ferrosos obteve importante avanço quando as técnicas de microscopia eletrônica de transmissão foram empregadas para observação desta estrutura [26] Os dois mecanismos de deformação plástica, escorregamento e maclação, observados nas transformações martensíticas, puderam ser melhor compreendidos. A partir deste período, sob o ponto de vista cristalográfico, a martensita pode ser classificada em martensita escorregada ("lath martensite") e martensita maclada ("plate martensite") [6,23,24,26].

A martensita escorregada, mais comum em aços baixo e médio carbono, possui planos de hábito que normalmente podem sofrer variações dentro de cada grão. O plano de hábito muda de acordo com a porcentagem de carbono. Aços com baixos teores de carbono apresentam plano de hábito $\{111\} \gamma$, enquanto que aços com teores entre $0,5 \mathrm{e}$ $1,4 \%$ de carbono apresentam plano de hábito $\{225\} \gamma$. Aços com teor em carbono superior a 1,4\% apresentam plano de hábito \{259\}y. Há também uma relação de orientação entre o novo reticulado martensítico, tetragonal, com a austenita [24].

As unidades de martensita se formam no contorno das linhas de escorregamento, agrupadas em grandes pacotes. A subestrutura consiste de alta densidade de discordâncias arranjadas em células. Cada martensita escorregada é composta de inúmeras células de discordâncias com largura média de $2500 \AA$. A densidade de discordâncias é estimada entre 0,3 e $0,9 \times 10^{13} \mathrm{~cm} / \mathrm{cm}^{3}[24,25]$.

Outro tipo de martensita, mais predominante em aços alto carbono, é a martensita maclada. As unidades de martensita se formam como placas lenticulares individuais. A subestrutura da martensita maclada consiste de finas maclas com espaçamento de aproximadamente $50 \AA[23,24]$. Essas maclas geralmente não se prolongam para fora dos limites da placa, mas se degeneram em deslocamentos complexos junto à periferia da placa.

A temperatura na qual a transformação martensítica se inicia é chamada de "martensite start", recebendo a sigla $M_{s}$. Na realidade, o $M_{s}$ de um aço reflete a força termodinâmica necessária para iniciar a transformação da austenita em martensita.

A figura 6 apresenta o significativo decréscimo dos valores de $M_{s}$ para o aumento no teor de carbono dos aços. A participação da martensita escorregada, maclada e mista, em ligas Fe-C também está representada. 


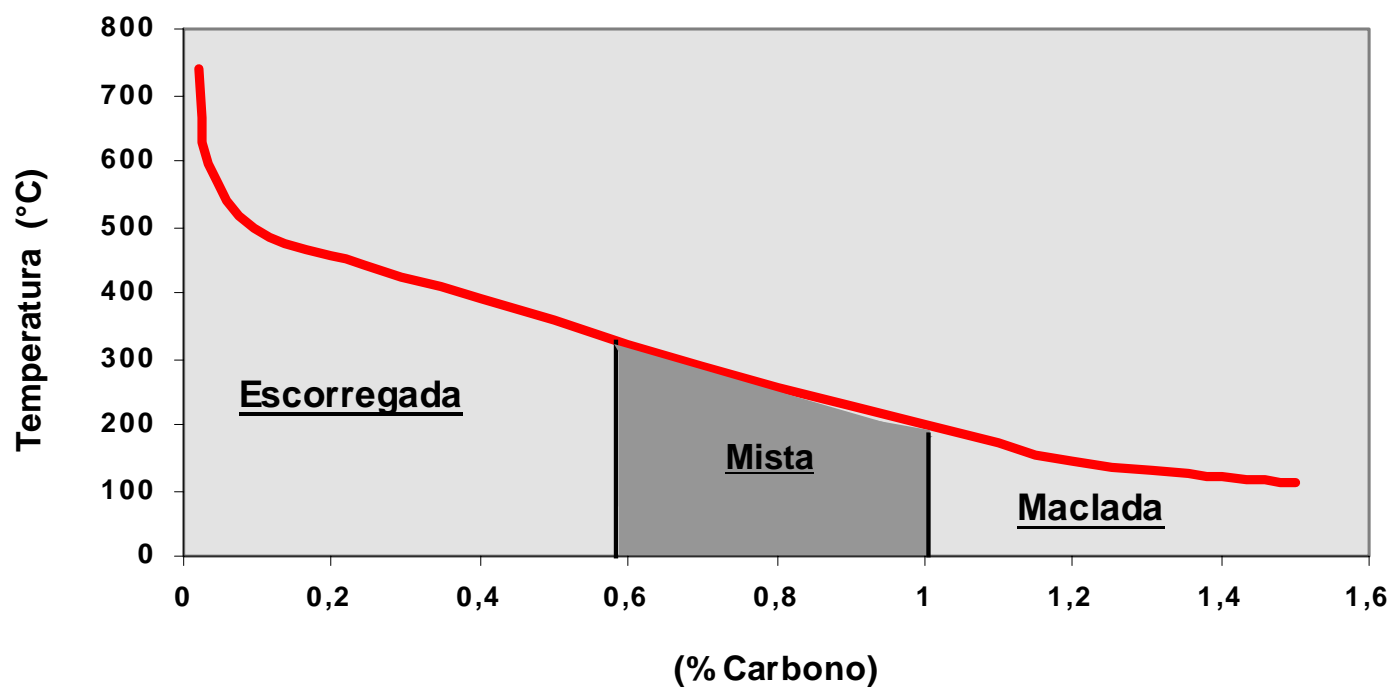

Figura 6: Curva representando o $\mathrm{M}_{\mathrm{s}}$ conforme os teores de $\mathrm{C}$ nos aços, bem como o tipo de cristalografia esperada [6].

A curva que representa $0 M_{s}$, mostrada na figura 6 , indica 0 início da transformação martensítica, momento este em que coexistem a martensita e a austenita, sendo que se observa um acréscimo da martensita à medida em que a temperatura decresce. A temperatura do final da transformação martensítica é chamada "martensite finish" levando a sigla $M_{f}$. De uma maneira geral, atribui-se um valor a $M_{f}$, correspondente a $120^{\circ} \mathrm{C}$ abaixo do Ms, embora esta diferença também varie de acordo com os teores de carbono e elementos de liga $[6,23,25]$.

Também se pode inferir pela figura 6 a influência do teor de carbono na morfologia dos cristais na microestrutura martensítica. A martensita escorregada aparece relacionada aos aços baixo carbono, enquanto a martensita maclada se relaciona aos aços alto C, surgindo uma região de separação entre ambas, onde uma cristalografia mista se apresenta.

No caso específico dos aços-ferramenta, os elementos de liga formadores de carbonetos também influenciam a temperatura $M_{s}$. Embora os teores de $C$ possuam grande participação na referida influência, elementos como $\mathrm{Mn}, \mathrm{Cr}, \mathrm{Ni}, \mathrm{Mo}, \mathrm{Si}$, e W reduzem o valor da temperatura $M_{s}[11]$. De fato, durante a austenitização a austenita se enriquece em $\mathrm{C}$ e elementos de liga (provenientes da dissolução de carbonetos) dificultando a transformação martensítica [27].

No que se refere às temperaturas de austenitização, sabe-se que para os aços carbono em geral, o aumento destas temperaturas, se revertem em crescimento de grão austenítico. 
De forma análoga a esferoidização, a força motriz termodinâmica que atua no crescimento do grão é a redução da energia interna de interface, traduzida pelo crescimento do grão às custas de grãos menores. O crescimento sem a presença de partículas segue de forma contínua à medida que cresce o tempo de exposição à temperatura de austenitização [20,27].

Para os aços-ferramenta alta liga, os quais apresentam microestrutura com importante distribuição de partículas de segunda fase, o crescimento de grão é retardado. Assim, os carbonetos que coexistem em uma estrutura típica de aço-ferramenta, atuam com a função extra de controlar o tamanho de grão durante a austenitização $[12,27]$.

Embora a transformação martensítica ocorra durante o resfriamento brusco da austenita nos aços-ferramenta, as características do grão austenítico estarão presentes após a obtenção da estrutura final temperada e revenida. Tais fatores influenciam as propriedades mecânicas e a tenacidade, importantes na aplicação das ferramentas.

\subsubsection{Martensita revenida}

Como as estruturas martensíticas são frágeis, o tratamento térmico do revenido se torna fundamental para o resgate parcial de uma estrutura com maior tenacidade. $\mathrm{Na}$ prática, o revenido é um tratamento térmico subcrítico que consiste em submeter os aços temperados a uma faixa de temperatura inferior à eutetóide, promovendo um patamar, seguido novamente de resfriamento até a temperatura ambiente, por repetidas vezes, se necessário [12,20,23]. Tal processo envolve a segregação do carbono em defeitos do reticulado, a precipitação de carbonetos, a decomposição da austenita retida e a recuperação e recristalização da estrutura martensítica. Assim, o objetivo do tratamento do revenido é facilitar fenômenos de difusão para se alcançar uma estrutura mais estável e menos frágil. Tais fenômenos ocorrem em escala nanoscópica e, assim como no caso da martensita, somente a partir do aperfeiçoamento das técnicas de microscopia eletrônica de transmissão (MET) em meados da década de 50, assim como do desenvolvimento de ensaios com difração de elétrons em áreas selecionadas, foi possível se compreender com mais exatidão os detalhes de uma estrutura martensítica revenida [26].

Antes mesmo de se aplicar o tratamento térmico do revenido, os aços temperáveis podem, durante o resfriamento da têmpera, sofrer um processo de revenimento enquanto se forma a martensita, principalmente quando a temperatura de início de formação da martensita é relativamente elevada, possibilitando os processos de

difusão do carbono. Este fenômeno recebe o nome de auto-revenido, e depende da 
velocidade de resfriamento, responsável por ditar o tempo de permanência nessas temperaturas.

Especificamente no caso de aços alta liga, isto é, com altos teores de carbono e elementos de liga, a martensita maclada se apresenta como microestrutura predominante. Neste caso, poucas posições de baixa energia (associadas a defeitos) se encontram disponíveis. Assim, a segregação do carbono para discordâncias parece não ser a única forma de migração [20, 24].

Referindo-se propriamente ao tratamento térmico do revenido, sabe-se que um aço com estrutura martensítica, submetido a tratamento térmico de revenido, segue uma seqüência caracterizada por três etapas distintas e superpostas, como segue:

\subsubsection{Primeira etapa do revenido}

No intervalo entre $100^{\circ} \mathrm{C}$ e $250^{\circ} \mathrm{C}$, embora se obtenha um aumento da tenacidade, não se observam alterações estruturais via microscopia óptica. Nesta faixa de temperatura, o carbono pode se difundir através do reticulado da martensita, inicialmente migrando para os locais de baixa energia, como defeitos, formando aglomerados de carbono ou se precipitando na forma de um carboneto metaestável, hexagonal compacto $(\mathrm{HC})$, denominado carboneto $\varepsilon$. Tal carboneto é semicoerente e apresenta estequiometria aproximada $\mathrm{Fe}_{2,4} \mathrm{C}[11,25,28]$.

Nos aços baixo carbono, a precipitação do carboneto $\varepsilon$ é inibida durante 0 tratamento de revenido na faixa de $100^{\circ} \mathrm{C}$ a $250^{\circ} \mathrm{C}$ justamente porque o carbono nestes aços se encontra preferencialmente nos locais de discordâncias, o que representa baixa energia de ativação para formação de precipitados [28,29].

Em se tratando de aços com teores de carbono mais elevados e com presença de elementos de liga, devido à saturação de carbono nestes locais de baixa energia, a precipitação de carbonetos se inicia rapidamente mesmo a temperaturas da ordem de $150^{\circ} \mathrm{C}$. O carboneto "Hägg" de estequiometria $\mathrm{Fe}_{5} \mathrm{C}_{2}$, estrutura monoclínica, inicia sua precipitação em aços alto carbono, na faixa de $200^{\circ} \mathrm{C}$. Esse carboneto é metaestável sendo considerado um carboneto intermediário entre $o \varepsilon$ e a cementita.

Um importante efeito do primeiro estágio é uma mudança do volume específico do metal. Neste caso o metal diminui de volume em vez de se expandir, como se observa na transformação da austenita para martensita [22,25,28]. A matriz é dita martensita decomposta sendo uma estrutura tetragonal de baixo carbono [29]. 


\subsubsection{Segunda etapa do revenido}

No segundo estágio, as frações de austenita retida se transformam em estrutura bainítica em temperaturas entre $100^{\circ} \mathrm{C}$ e $300^{\circ} \mathrm{C}$. Tal estrutura é basicamente composta de ferrita e carboneto $\varepsilon$ [25]. Este estágio é acompanhado de importante variação dimensional expansiva. Vale ressaltar a presença do referido carboneto nos dois estágios iniciais do revenido, destacando-se como diferença, a matriz em que estão inseridos. No segundo estágio destaca-se a matriz bainítica, composta de ferrita de estrutura cúbica $[25,28,30]$.

\subsubsection{Terceira etapa do revenido}

Neste estágio, que ocorre normalmente na faixa entre $200^{\circ} \mathrm{C}$ e $400^{\circ} \mathrm{C}$, os carbonetos $\varepsilon$ se dissociam e o C em excesso se difunde 'para fora' da martensita, que perde a tetragonalidade, tornando-se essencialmente ferrita encruada e cementita. Assim como no primeiro estágio, o terceiro se caracteriza pela diminuição do volume de metal.

Para temperaturas superiores a $400^{\circ} \mathrm{C}$, observa-se importante decréscimo nos valores de dureza mesmo para aços com médio teor de $C$, uma vez que o mecanismo de recuperação passa a atuar de forma mais intensa, com rearranjo e aniquilamento de discordâncias $[18,29,30]$.

\subsubsection{Revenimento dos aços-ferramenta}

O tratamento térmico do revenido é usualmente aplicado para os aços-ferramenta com o objetivo de se atingir um balanço entre dureza e tenacidade, dependendo da aplicação final da ferramenta, assim como promover o denominado endurecimento secundário. Este último fenômeno caracteriza-se pela precipitação de carbonetos secundários, responsáveis por importante incremento na resistência ao desgaste dos aços-ferramenta. Tal fenômeno foi primeiramente relatado por Bain e Jeffries em pioneiro estudo realizado em aços rápidos [12,13,24].

A precipitação de carbonetos na chamada quarta etapa do revenido, presente nos aços-ferramenta, é a maior responsável pelo incremento da dureza.

Devido à presença de um alto teor de elementos de liga, os aços-ferramenta apresentam certas variações na seqüência de transformações presentes nas etapas do revenido, quando comparados aos aços baixa liga. A tabela 7 apresenta a seqüência de transformações para um aço baixa liga e um aço-ferramenta $[12,25,29,30]$. 
Tabela 7: Comparação entre o revenido tradicional de um aço baixa liga e de um açoferramenta.

\begin{tabular}{c|c|c}
\hline $\begin{array}{c}\text { TEMPERATURAS DE } \\
\text { REVENIDO }\end{array}$ & AÇO BAIXA LIGA ${ }^{(1)}$ & AÇO-FERRAMENTA $^{(2)}$ \\
\hline $\begin{array}{c}\text { Etapa } 1 \\
100 \text { a } 250^{\circ} \mathrm{C}^{(1)}\end{array}$ & $\begin{array}{c}\text { Aglomerados de C } \\
\text { e precipitação }\end{array}$ & $\begin{array}{c}\text { Precipitados finos } \\
\text { (carbonetos de transição) }\end{array}$ \\
\hline $\begin{array}{c}\text { Etapa } 2 \\
150 \text { a } 300^{\circ} \mathrm{C} \\
200 \text { a } 600^{\circ} \mathrm{C}\end{array}$ & $\begin{array}{c}\text { Austenita retida } \\
\text { transformada em bainita }\end{array}$ & $\begin{array}{c}\text { Austenita retida transforma- } \\
\text { se em } \mathrm{M}_{3} \mathrm{C} \text { e ferrita }\end{array}$ \\
\hline $\begin{array}{c}\text { Etapa } 3 \\
200 \text { a } 400^{\circ} \mathrm{C}\end{array}$ & $\mathrm{M}_{3} \mathrm{C}$ & $\mathrm{M}_{3} \mathrm{C}$ \\
acima $200^{\circ} \mathrm{C}$ & $\mathrm{Fe}_{3} \mathrm{C}$ & \\
\hline Etapa 4 & -- & $\begin{array}{c}\text { Endurecimento secundário } \\
\text { (Carbonetos ligados) }\end{array}$ \\
acima de $400^{\circ} \mathrm{C}$ & \multicolumn{2}{c}{}
\end{tabular}

Primeiramente, observando-se a tabela 7 , nota-se que os aços-ferramenta podem apresentar uma quarta etapa do revenido, pelo mencionado fenômeno do endurecimento secundário, não presente para aços baixa liga [25]. Os aços ligados têm seu revenido modificado de acordo com o tipo e o teor dos elementos de liga. Pode-se também inferir que a primeira etapa do revenido também envolve o surgimento de carbonetos de transição e os efeitos dos elementos de liga como $\mathrm{V}, \mathrm{Cr}$, W e Mo parecem não relevantes uma vez que estes, devido aos seus raios atômicos, ocupam posições substitucionais, necessitando temperaturas superiores para se difundirem $[20,29]$.

A temperaturas mais altas, durante a segunda e terceira etapas, ocorre a formação de carbonetos tipo $\mathrm{M}_{3} \mathrm{C}$, onde "M" designa o elemento de liga formador de carboneto.

Alguns aços-ferramenta, como os aços rápidos e os aços para trabalho a frio alto C - alto $\mathrm{Cr}$, a partir de $500^{\circ} \mathrm{C}$, apresentam a referida quarta etapa do revenido (endurecimento secundário), que em termos de propriedades, retarda a queda das propriedades mecânicas, promovendo ainda um incremento nos valores de dureza [20, $25,29]$.

De uma maneira geral, no caso dos aços-ferramenta, o aquecimento gerado pelo tratamento de revenido promove uma diminuição no supersaturamento do carbono presente na estrutura martensítica. $\mathrm{Na}$ verdade, as temperaturas elevadas de revenido aplicadas para esta classe de aços permitem a difusão de átomos de elementos de liga substitucionais, fazendo com que ocorra a precipitação de carbonetos. Embora a martensita seja descrita nos aços-ferramenta como importante matriz, responsável pela manutenção do carbono na estrutura, deve-se ressaltar que a mesma apresenta 
importante papel quando se constitui em fonte de C para precipitação de carbonetos, responsáveis, por exemplo, pelo endurecimento secundário.

\subsubsection{Carbonetos nos aços-ferramenta.}

Os aços-ferramenta são produzidos a partir de um projeto de liga que contendo elementos de transição, denominados formadores de carbonetos, como $\mathrm{Cr}$, Mo, W e V. Tais elementos visam promover uma grande fração volumétrica de carbonetos gerando alta dureza e elevada resistência ao desgaste. Por outro lado, a complexidade observada nestas microestruturas leva esta classe de aços a apresentar baixos valores de ductilidade e tenacidade, além de difícil usinabilidade. Durante o processo de solidificação, os aços-ferramenta começam a apresentar carbonetos que continuam a se formar durante o processamento a quente do mesmo e posteriores tratamentos térmicos como austenitização, têmpera e revenido [31,32].

A tabela 8 apresenta uma lista e as características dos carbonetos que podem estar presentes nos aços-ferramenta. A letra "M" presente na designação dos carbonetos representa um metal que pode ocupar um espaço no reticulado da estrutura cristalina do carboneto.

Tabela 8: Principais carbonetos nos aços-ferramenta [5,20,31].

\begin{tabular}{c|c|c|l}
\hline TIPO & RETICULADO & $\begin{array}{c}\text { DUREZA } \\
(\mathrm{HV})\end{array}$ & \multicolumn{1}{|c}{ CARACTERÍSTICAS } \\
\hline $\mathrm{M}_{3} \mathrm{C}$ & Ortorrômbico & 900 & $\begin{array}{l}\text { Derivado da cementita; "M" pode representar Mn, } \\
\text { Cr e menos freqüente W, Mo, V. }\end{array}$ \\
\hline $\mathrm{M}_{23} \mathrm{C}_{6}$ & CFC & 1300 & $\begin{array}{l}\text { Também presente com alta incidência nos aços- } \\
\text { ferramenta alto Cr. } \\
\text { O Cr pode ser substituído por W ou Mo. }\end{array}$ \\
\hline $\mathrm{M}_{7} \mathrm{C}_{3}$ & Hexagonal & 1600 & $\begin{array}{l}\text { Muito presente em aços-ferramenta alto Cr. } \\
\text { Resistente à dissolução em altas temperaturas }\end{array}$ \\
\hline $\mathrm{M}_{6} \mathrm{C}$ & CFC & 1700 & $\begin{array}{l}\text { Carboneto onde "M" tipicamente é W ou Mo. } \\
\text { Pode conter moderados teores de Cr e V. }\end{array}$ \\
\hline $\mathrm{M}_{2} \mathrm{C}$ & Hexagonal & 2200 & $\begin{array}{l}\text { Carboneto rico em W ou Mo, típico de revenido, } \\
\text { dissolvendo também consideráveis teores de Cr. }\end{array}$ \\
\hline $\mathrm{MC}$ & CFC & 3000 & $\begin{array}{l}\text { Carboneto rico em V. } \\
\text { Extremamente estável e resistente ao desgaste. }\end{array}$ \\
\hline
\end{tabular}

Os carbonetos são partículas de elevada dureza, levando-se em conta que uma matriz temperada em um aço-ferramenta, apresenta valor médio de 800 HV [10, 31]. 
Os carbonetos originados na fase líquida do aço-ferramenta são denominados carbonetos primários. A precipitação desses carbonetos ocorre durante a solidificação a partir de carbonetos em rede, situados nos contornos de grãos austeníticos. Os carbonetos primários com formato de "espinha de peixe" são associados aos tipos $\mathrm{M}_{6} \mathrm{C}$, enquanto os tipos $\mathrm{M}_{2} \mathrm{C}$ são ligados ao formato de bastonetes e os tipos $\mathrm{MC}$ à forma globular. A distinção entre os carbonetos se torna difícil após submeter os açosferramenta à deformação plástica (como laminação e forjamento), a qual será responsável pelo rompimento do carboneto, dificultando ou impossibilitando seu reconhecimento. [32]

Além dos carbonetos primários, uma série de outros precipitados se formam nos aços-ferramenta, carbonetos estes classificados como secundários. Os carbonetos secundários, por sua vez, se subdividem em carbonetos advindos do recozimento e aqueles oriundos das etapas do revenido.

A quantidade de carboneto secundário que precipita a partir da austenita durante o resfriamento da têmpera é muito baixa. Os mesmos podem ser observados como uma fina camada sobre os contornos de grão após a têmpera [31,32].

Sabe-se que na condição apenas temperado, os aços-ferramenta -alta liga apresentam metade de seus elementos de liga em solução sólida na matriz martensítica [31]. Após o tratamento do revenido, baixas porcentagens destes elementos permanecem na matriz. As primeiras precipitações de carbonetos ligados só ocorrem na chamada quarta etapa do revenido ou endurecimento secundário. Tais carbonetos se situam tanto nos contornos de grão como nos espaçamentos presentes na estrutura martensítica. Esta etapa pode ser considerada essencial para algumas aplicações dos aços-ferramenta que devem apresentar resistência ao revenido.

Segundo Roberts e Krauss [5,12], aparecem em ordem decrescente quanto à efetividade no retardo da queda das propriedades mecânicas os elementos $\mathrm{V}, \mathrm{Mo}, \mathrm{W}, \mathrm{Cr}$, Si e praticamente nenhum efeito para Ni e Mn. Uma vez que os aços-ferramenta alta liga como os aços para trabalho a frio alto $\mathrm{C}$ - alto $\mathrm{Cr}$ possibilitam o endurecimento secundário, o revenido de tais ligas ocorre em temperaturas de até $570^{\circ} \mathrm{C}$.

Sabe-se que na quarta etapa de revenido formam-se carbonetos coerentes, finamente dispersos na matriz [31,33]. No endurecimento por precipitação coerente o reticulado cristalino da matriz e o precipitado apresentam um certo grau de coerência, sendo o endurecimento devido às tensões elásticas, advindas do desajuste entre os parâmetros do reticulado do precipitado e da matriz.

Segundo Porter [33], o carboneto $\varepsilon$ não se transforma diretamente em $\mathrm{Fe}_{3} \mathrm{C}$ por decomposição, mas dissolve-se na matriz, para posterior formação de $\mathrm{Fe}_{3} \mathrm{C}$. No que se 
refere à transformação da cementita em carbonetos ligados, dois mecanismos se apresentam [33]:

- transformação "in situ" - os carbonetos nucleiam na interface martensita / cementita e crescem até o desaparecimento da cementita.

- nucleação e crescimento - os carbonetos ligados nucleiam heterogeneamente nas discordâncias da martensita, nos contornos das ripas (contornos de baixo ângulo) e nos contornos de grãos da austenita anterior à têmpera. Os carbonetos crescem às custas da dissolução da cementita.

É possível a simultaneidade de ambos os mecanismos, dependendo da composição do aço, uma vez que a presença de elevado teor de elementos de liga possibilita importantes transformações de cementita em carbonetos.

$\mathrm{Na}$ tabela 9 está apresentada a temperatura de formação dos carbonetos em aços-ferramenta e a sua respectiva morfologia durante o revenido.

Tabela 9: Temperatura de formação dos carbonetos durante o revenido [31,33].

\begin{tabular}{c|c|c}
\hline CARBONETO & MORFOLOGIA & $\begin{array}{c}\text { TEMPERATURA } \\
\text { MÉDIA DE } \\
\text { FORMAÇÃO }\left({ }^{\circ} \mathrm{C}\right)\end{array}$ \\
\hline$\varepsilon\left(\mathrm{Fe}_{2,4} \mathrm{C}\right)$ & Ripa & 100 \\
\hline Cementita $/ \mathrm{M}_{3} \mathrm{C}$ & Ripa & 250 \\
\hline $\mathrm{VC}-\mathrm{V}_{4} \mathrm{C}_{3}$ & Placa & 530 \\
\hline $\mathrm{Mo}_{2} \mathrm{C}$ & - & 530 \\
\hline $\mathrm{W}_{2} \mathrm{C}$ & Agulhas & 600 \\
\hline $\mathrm{Cr}_{7} \mathrm{C}_{3}$ & Esfera & 500 \\
\hline $\mathrm{Cr}_{23} \mathrm{C}_{6}$ & Placa & - \\
\hline $\mathrm{M}_{6} \mathrm{C}$ & - & 700 \\
\hline
\end{tabular}

Observa-se pela tabela 9 que a precipitação de carbonetos contendo elementos de liga, apenas se inicia para faixas de temperatura acima de $500^{\circ} \mathrm{C}$. Para temperaturas abaixo desta última, os elementos de liga substitucionais não apresentam mobilidade suficiente para precipitar carbonetos. Mesmo assim, os poucos precipitados que se formam tendem a apresentar tamanho reduzido devido às pequenas distâncias percorridas pelos elementos de liga.

A temperaturas superiores a $500^{\circ} \mathrm{C}$ os elementos de liga substitucionais se difundem em médias distâncias e tendem a formar carbonetos mais complexos, fator primordial para o fenômeno do pico de dureza apresentado por aços-ferramenta alto C I $\mathrm{Cr}$, durante o endurecimento secundário.

No caso específico dos aços-ferramenta para trabalho a frio alto C-alto $\mathrm{Cr}$, a seqüência de formação de carbonetos durante o revenido é dada por $M_{3} C, M_{7} C_{3}$ e $M_{23} C_{6}$. 


\subsection{Algumas propriedades e mecanismos}

\subsubsection{Desgaste}

Desgaste é um fenômeno de superfície causado pela interação entre corpos em contato. Para ferramentas, o desgaste pode ser classificado em dois tipos: abrasivo e adesivo [34].

\section{a) Desgaste adesivo}

Ocorre quando superfícies deslizam umas sobre as outras. Elevadas pressões localizadas entre asperezas em contato resultam em deformação plástica e, conseqüentemente, formação de junções. O deslizamento relativo entre as superfícies em contato promove a ruptura dessas junções, causando remoção de material e conseqüente desgaste $[5,6,10]$. A figura 7 ilustra situações onde ocorre desgaste adesivo.

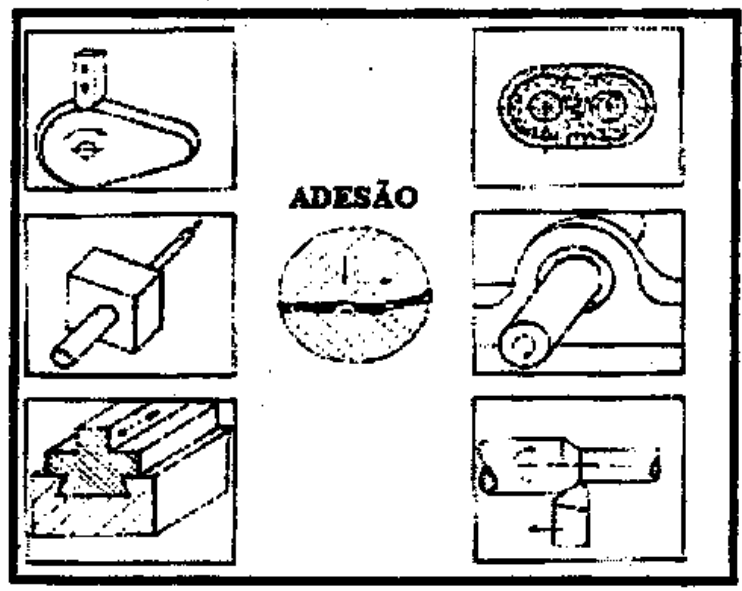

Figura 7: Situações de ocorrência de desgaste tipo adesivo.

\section{b) Desgaste abrasivo}

O desgaste abrasivo é definido como o deslocamento de material causado pela presença de partículas duras entre, ou embebidas, em uma ou ambas as superfícies em movimento relativo, ou pela presença de protuberâncias duras em ambas as superfícies. A figura 8 ilustra situações onde ocorre desgaste abrasivo. 


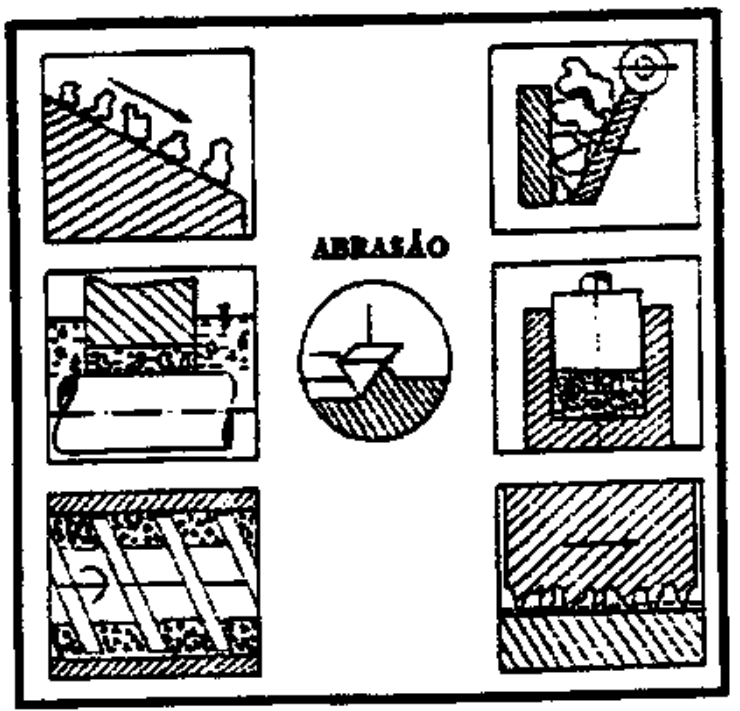

Figura 8: Situações de ocorrência de desgaste tipo abrasivo.

Geralmente, ambos os mecanismos ocorrem durante o desgaste de uma ferramenta. A contribuição maior ou menor, de um dos mecanismos dependerá de cada aplicação. Pode-se citar a operação de forjamento a quente onde o principal desgaste é o "desgaste abrasivo". Na operação de injeção de plástico de baixa abrasividade, polipropileno, por exemplo, o desgaste adesivo é predominante [35].

\subsubsection{Dureza}

Essa propriedade comporta três enfoques básicos:

\section{a) Dureza a quente}

Propriedade importante nos processos industriais a quente como forjamento, extrusão de metais, laminação, etc. Define-se "dureza a quente" como a capacidade do aço de manter sua dureza superficial a altas temperaturas. Nos processos de extrusão de alumínio, por exemplo, onde o ambiente de trabalho está em torno de $500^{\circ} \mathrm{C}$ e a ferramenta próxima de $450^{\circ} \mathrm{C}$. Para garantir que não haverá perda de dureza da ferramenta trabalhando nessas condições, a operação de revenimento no tratamento térmico deverá ser realizada a temperaturas superiores e, para tanto, o aço-ferramenta escolhido deverá ter composição química adequada para atender a essa exigência. 
b) Profundidade de dureza

Essa propriedade está relacionada diretamente com 0 conceito de "temperabilidade" (capacidade do aço de adquirir dureza a uma certa profundidade). A uniformidade e profundidade de dureza, resultantes de propriedades mecânicas homogêneas, também será útil naqueles casos onde se deseja recuperar a ferramenta através de uma nova usinagem.

c) Dureza superficial

Essa propriedade diz respeito apenas à superfície de trabalho da ferramenta, independente da profundidade de dureza que se alcança. Geralmente, é essa propriedade que se solicita, e se examina, nos tratamentos térmicos podendo, portanto, ser ajustada conforme aplicação do aço-ferramenta.

\subsubsection{Tenacidade}

Tenacidade é a medida da energia necessária para romper o material. Essa energia - produto de uma força multiplicada por um deslocamento - é medida em "lb.ft", "KPM" $(9,8 \mathrm{~J})$ ou "kgf.m" e está relacionada com a área sob a curva "tensão x deformação".

De forma geral, quanto maior o limite de escoamento e a ductilidade (deformação total até ruptura) do material, maior a tenacidade [36]. A avaliação da tenacidade é realizada pelo ensaio denominado "Ensaio de Charpy" em corpos de prova não entalhados, adequadamente preparados conforme normas - ASTM [37].

\subsubsection{Usinabilidade}

Avalia a capacidade de corte do aço-ferramenta durante o processo de produção de outras peças. 


\subsubsection{Fadiga}

Fadiga pode ser definida como a indução de esforços cíclicos aplicados num determinado intervalo de tempo. Operações industriais como forjamento a quente, extrusão e injeção de alumínio, por exemplo, desenvolvem gradientes térmicos cíclicos; operações de conformação a frio que introduz ciclos de carregamento/descarregamento de tensões, são exemplos típicos onde o aço-ferramenta experimenta perda de resistência à fadiga $[3,10]$.

As falhas por fadiga na sua grande maioria apresentam caráter frágil, ou seja, sem deformação plástica visível. Na sua superfície em geral pode-se notar as chamadas marcas de praia ("beach marks"), que delimitam as posições sucessivas de caráter macroscópico da propagação da trinca. Quando a superfície da peça possui entalhes, trincas paralelas nucleiam independentemente e, ao crescerem, se juntam em degraus, denominados de marcas de catraca ("ratched marks"), em geral perpendiculares à superfície das peças. A figura 9 mostra essas marcas.

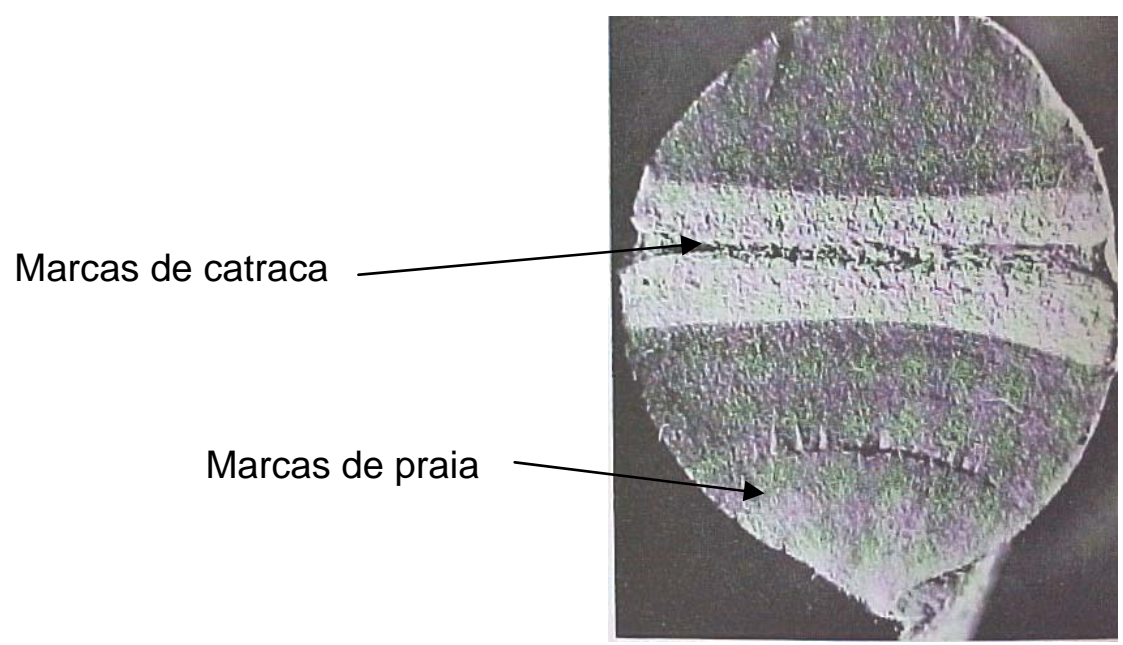

Figura 9: Área de fratura de um eixo aço carbono [10].

Observando-se superfícies de fratura por fadiga ao microscópico eletrônico de varredura, pode-se, em algumas classes de materiais como, por exemplo, aços inoxidáveis austeníticos, encontrar as "estrias de fadiga". Estas são muito pequenas da ordem de micra, e cada estria corresponde a um ciclo de fadiga, mas nem todo ciclo de fadiga corresponde a uma estria de fadiga. O efeito do acabamento superficial na resistência a fadiga é de importância fundamental. A fadiga também depende fortemente das tensões residuais, de tal modo que a aplicação de tratamento de alívio de tensões pode resultar em aumento da vida do componente. 


\section{MATERIAIS E MÉTODOS}

\subsection{Seleção dos aços-ferramenta para trabalho a frio}

Dois tipos básicos de aço-ferramenta poderiam ser empregados em trabalho a frio, dependendo do tipo de solicitação e da resposta requerida das ferramentas: os aços tipicamente baixa liga, por exemplo AISI O1 e S1, e aços com maiores teores de elementos de liga, como os AISI D2 e D6. Estes últimos são aplicados em ferramentas denominadas de alta solicitação, como matrizes de prensagem, matrizes de forjamento, facas de corte e punções. Nas ferramentas de alta solicitação, a resistência ao desgaste é a propriedade essencial. Tanto o AISI D2 como o AISI D6, possuem adequada resistência ao desgaste, gerada por uma matriz martensítica revenida e um elevado volume de carbonetos primários não dissolvidos. Contudo, possuem baixa tenacidade, uma propriedade essencial para evitar falhas por trincas, lascas e fratura prematura das ferramentas.

Aços rápidos, como o AISI M2 e M4, são utilizados quando as solicitações em relação à resistência ao desgaste são extremas. Embora sejam alcançadas melhorias de desempenho, o uso de aços rápido em aplicações de trabalho a frio é limitado, devido ao elevado custo do material e do tratamento térmico. O aço VF-800® foi desenvolvido pela siderúrgica de origem brasileira Villares Metals S.A com promessa de elevada tenacidade e alta resistência ao desgaste. Este aço apresenta um custo reduzido de material e entra como opção para aplicação que requer altas solicitações de resistência ao desgaste. Outro aço muito utilizado pela indústria, o AISI O1, também produzido pela Villares Metals S.A com nome comercial VND®, também está presente neste trabalho para efeito de ilustrar a evolução dos aços [21].

A série de aços-ferramenta desenvolvidos para alto desempenho, típica dos processos da metalurgia do pó, foram desenvolvidos para diferentes aplicações. Dentre estas ligas, o aço sinterizado Vanadis $10 \AA$, classificado como aço-ferramenta para trabalho a frio e desenvolvido pela siderúrgica de origem sueca Uddeholm Tooling $A B$, foi o material escolhido para este trabalho. Tal liga apresenta certa similaridade de composição química com o aço AISI D7, sendo promessa de aplicação em situações 
típicas de utilização de ligas convencionais. O último aço que foi selecionado para este trabalho também acompanha a tendência de otimização da relação dureza e tenacidade. Este aço-ferramenta é o Calmax®, também fabricado pela Uddeholm Tooling $A B$, só que produzido por rota convencional de metalurgia, apresenta grande relação durezatenacidade com grande resistência ao desgaste [16]. Os aços-ferramenta VF-800 e Vanadis 10 apresentam a chamada quarta etapa do revenido, caracterizada pela estabilidade dos carbonetos ricos em cromo de estequiometria $\mathrm{MC}$ e $\mathrm{M}_{7} \mathrm{C}_{3}$ [5].

Os aços estudados apresentam, de uma forma geral, aplicação crescente em substituição aos aços AISI D2 e AISI D6 fabricados por metalurgia convencional, principalmente nos mercados da Europa e América do Norte. Embora aços-ferramenta desta classe apresentem altos valores de dureza, devido aos altos teores de C, Cr e com teores significativos de $\mathrm{V}$ e Mo, alternativas de tratamento térmico para agregar maior tenacidade vem adquirindo destaque na última década, tendendo a potencializar ainda mais as propriedades ligadas à tenacidade.

Apesar do grande número de estudos se referindo às propriedades tribológicas destes novos aços, observa-se uma lacuna no que se refere ao estudo da tenacidade destes materiais e principalmente com relação ao efeito dos tratamentos térmicos sobre o comportamento mecânico dos mesmos. É importante ressaltar que apesar das propriedades ligadas à resistência ao desgaste serem de interesse primordial nos açosferramenta, as respostas às solicitações mecânicas apresentam importância uma vez que falhas prematuras devido a esforços estáticos ou dinâmicos, inviabilizam a aplicação de uma ferramenta com elevada resistência ao desgaste sem tenacidade combinada em suas propriedades.

\subsection{Composição química}

A composição química nominal dos aços em estudo está apresentada na tabela 10, juntamente com a dos aços AISI O1, presente neste estudo, bem como aços AISI D2 e AISI D6. A comparação entre ambos mostra que os novos materiais apresentam teores de carbono e cromo reduzidos, porém com maior teor dos elementos molibdênio e vanádio. Essas modificações indicam preocupação com a tenacidade sem perda significativa na resistência ao desgaste. 
Tabela 10: Composição química nominal dos aços para trabalho a frio tradicionais (AISI D2 e AISI D6) e dos selecionados para este trabalho.

\begin{tabular}{c|c|c|c|c|c|c|c|c}
\hline Material & $\mathbf{C}$ & $\mathbf{S i}$ & $\mathbf{M n}$ & $\mathbf{C r}$ & $\mathbf{M o}$ & $\mathbf{V}$ & $\mathbf{W}$ & $\mathbf{N b}$ \\
\hline D2 & 1,55 & 0,40 & 0,30 & 11,50 & 0,70 & 1,00 & - & $<0,01$ \\
\hline D6 & 2,10 & 0,30 & 0,30 & 11,30 & 0,20 & 0,20 & 0,70 & $<0,01$ \\
\hline VND & 0,95 & 0,25 & 1,25 & 0,50 & - & 0,12 & - & $<0,01$ \\
\hline Calmax & 0,60 & 0,35 & 0,80 & 4,50 & 0,50 & 0,20 & - & $<0,01$ \\
\hline VF-800 & 0,85 & 0,90 & 0,40 & 8,40 & 2,10 & 0,50 & - & 0,15 \\
\hline Vanadis 10 & 2,90 & 0,50 & 0,50 & 8,00 & 1,50 & 9,80 & - & $<0,01$ \\
\hline
\end{tabular}

\subsection{Reposta ao tratamento térmico indicado pelo fabricante}

As curvas de revenimento dos materiais presentes neste estudo, fornecidas pelos fabricantes, estão apresentadas na figura 10 [13,16,19,21]. Para efeito comparativo foi inserida também a curva do AISI D2. O estudo do comportamento da curva de revenimento é importante para definir as temperaturas de revenimento adequadas ao tratamento térmico. A dureza, o índice de austenita retida, as distorções dimensionais após a têmpera, e o custo do tratamento térmico estão diretamente relacionados à temperatura de austenitização empregada que se manteve fixa. Aços-rápidos, utilizados como alternativa a matrizes de trabalho a frio de alta tenacidade, possuem desvantagem neste ponto, pois são normalmente austenitizados acima de $1150^{\circ} \mathrm{C}$ [27].

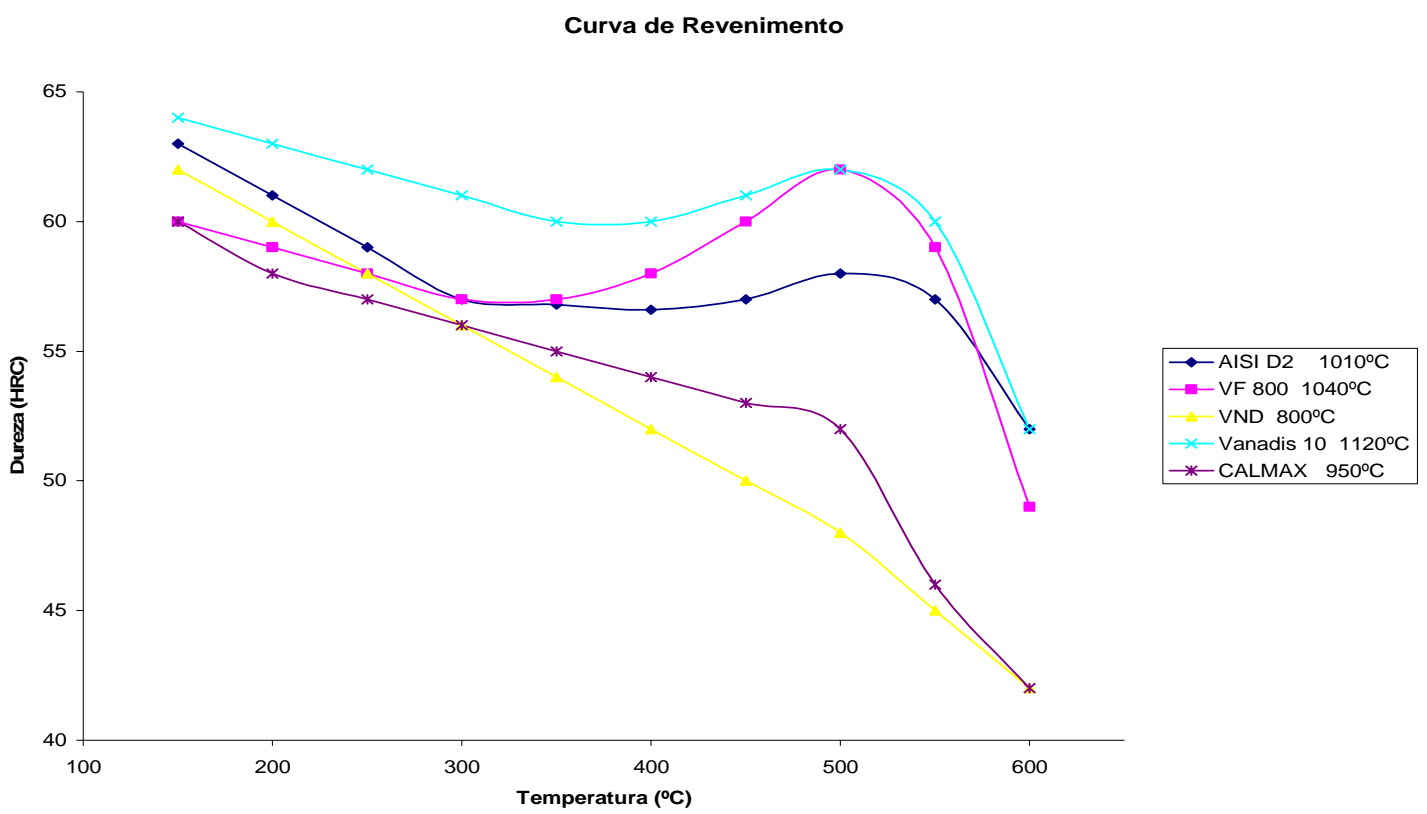

Figura 10: Curva de revenimento dos aços contidos no presente estudo e do aço AISI D2 [13,16,19,21]. As temperaturas indicadas são referentes a etapa de austenitização. 
Ainda em relação à resposta ao tratamento térmico, é importante notar que o pico secundário de dureza dos aços Vanadis 10 e VF-800 são mais intensos que o pico do aço AISI D2. Estes materiais possuem níveis de dureza acima de 60 HRC após revenimento em temperaturas acima de $500{ }^{\circ} \mathrm{C}$. O AISI D6, por exemplo, atinge os mesmos níveis apenas quando submetido ao revenimento (ou alívio de tensões) em torno de $160^{\circ} \mathrm{C}$. Portanto, em termos metalúrgicos, o mecanismo de endurecimento dos aços vanadis 10 e VF-800 já contribuem para obtenção de maior tenacidade.

A figura 11 mostra o fluxo de etapas e ensaios realizados durante o presente trabalho.
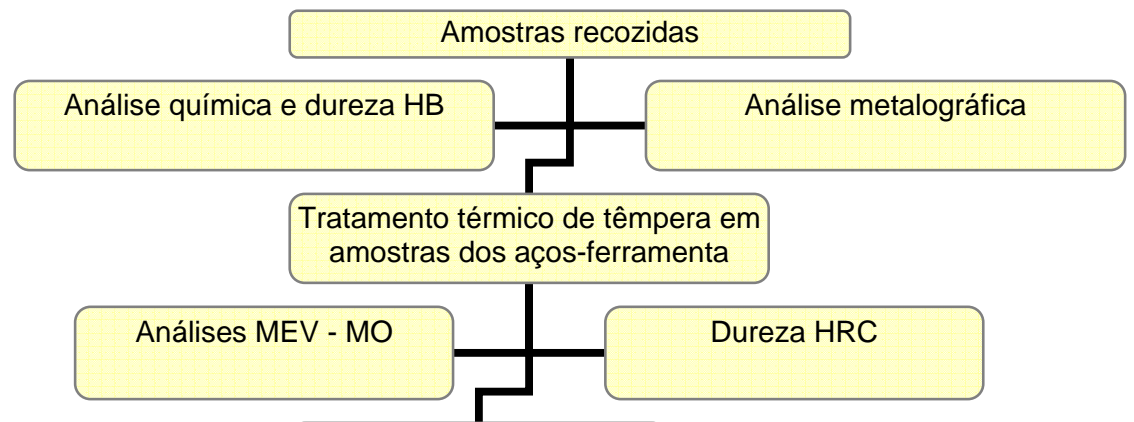

Estudo das curvas de revenimento

Preparação dos CP's

Tratamentos térmicos de revenido

Testes Mecânicos

Tração Flexão 4 pontos

Charpy
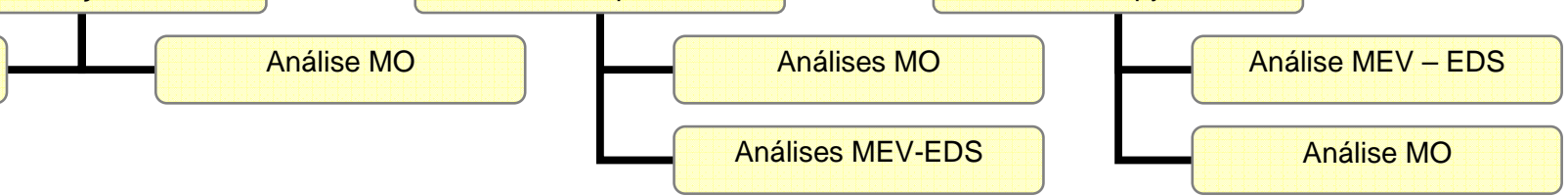

Figura 11: Fluxograma de etapas e ensaios realizados no projeto.

\subsection{Preparação dos corpos-de-prova para testes mecânicos}

A preparação dos corpos-de-prova de tração, Charpy (sem entalhe) e flexão 4pontos, foi efetuada em torno, fresa, plaina e retífica cilíndrica (para flexão 4-pontos). Foram preparados 10 corpos de prova para cada ensaio, conforme as especificações das normas ASTM E 8M [38], ASTM E -23 [37] e NBR 6157, e ASTM A-438 [39], respectivamente. As durezas foram obtidas a partir da média de cinco indentações. 
Tais corpos de prova foram preparados quando os aços em estudo se encontravam no estado recozido. As figuras 12, 13 e 14 trazem dimensões do corpo-deprova para os ensaios de tração, flexão 4-pontos e ensaio de impacto Charpy sem entalhe, respectivamente. Após os tratamentos térmicos os corpos-de-prova foram retificados até atingirem as dimensões finais especificadas.

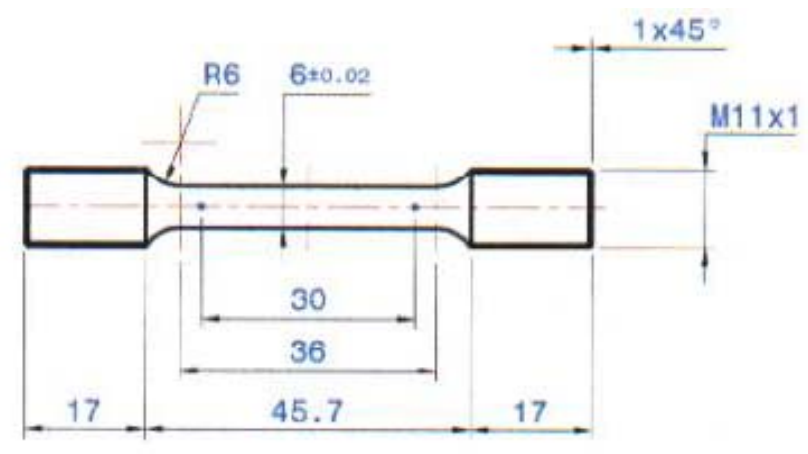

Figura 12: Dimensões do corpo=de-prova para ensaio de tração $[38,40]$.
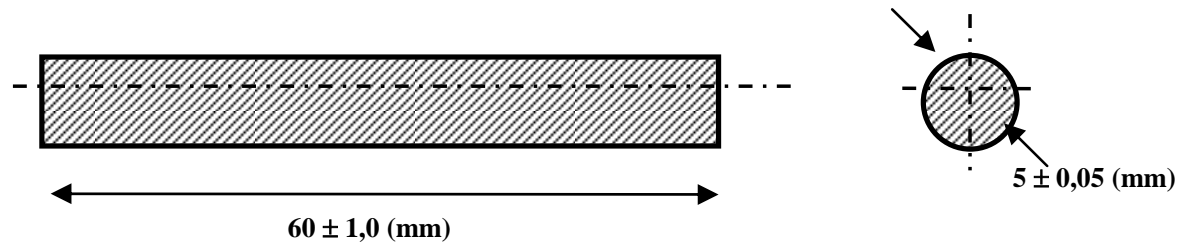

Figura 13: Dimensões do corpo-de-prova para ensaio de flexão 4-pontos $[39,40]$.
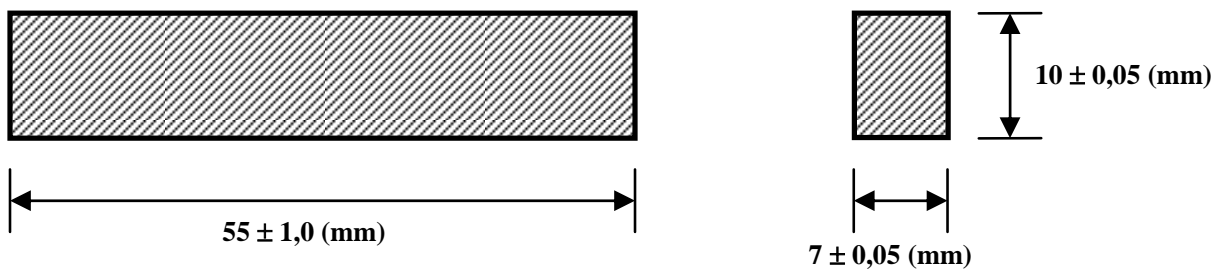

Figura 14: Dimensões do corpo-de-prova para ensaio de impacto Charpy sem entalhe $[37,40,41]$.

\subsection{Tratamentos térmicos}

\subsubsection{Têmpera}

Os tratamentos térmicos de têmpera foram realizados nas condições apresentadas na tabela 11 . O resfriamento foi efetuado em banho de sal. 
Tabela 11: Condições de têmpera dos aços-ferramenta em estudo [16,21].

\begin{tabular}{c|c|c|c}
\hline & \multicolumn{3}{|c}{ Condições de têmpera } \\
\hline Aços-ferramenta & Aquecimento & Austenitização & Resfriamento \\
\hline VND & $2 \mathrm{~h} \mathrm{a} 400^{\circ} \mathrm{C}$ & $15 \mathrm{~min}$ a $800^{\circ} \mathrm{C}$ & $5 \mathrm{~min}$ a $160^{\circ} \mathrm{C}$ \\
\hline CALMAX & $\begin{array}{c}2 \mathrm{~h} \mathrm{a} 400^{\circ} \mathrm{C}+ \\
10 \mathrm{~min} \mathrm{a} \\
800^{\circ} \mathrm{C}\end{array}$ & $8 \mathrm{~min}$ a $950^{\circ} \mathrm{C}$ & $2 \mathrm{~min} \mathrm{a} 520^{\circ} \mathrm{C}$ \\
\hline VF-800 & $\begin{array}{c}2 \mathrm{~h} \mathrm{a} 400^{\circ} \mathrm{C}+ \\
15 \mathrm{~min} \mathrm{a} \\
850^{\circ} \mathrm{C}\end{array}$ & $15 \mathrm{~min}$ a $1040^{\circ} \mathrm{C}$ & $10 \mathrm{~min} \mathrm{a} 520^{\circ} \mathrm{C}$ \\
\hline Vanadis 10 & $\begin{array}{c}2 \mathrm{~h} \mathrm{a} 400^{\circ} \mathrm{C}+ \\
20 \mathrm{~min} \mathrm{a} \\
850^{\circ} \mathrm{C}\end{array}$ & $8 \mathrm{~min}$ a $1120^{\circ} \mathrm{C}$ & $16 \mathrm{~min} \mathrm{a} 520^{\circ} \mathrm{C}$ \\
\hline
\end{tabular}

\subsubsection{Revenimento}

O tratamento térmico de revenimento seguiu os parâmetros conforme tabelas 12 a 15. As temperaturas foram escolhidas em função da curva de revenimento do fabricante, sendo típica a preferência entre temperaturas que apresentam o mesmo valor de dureza para o aço Calmax, e temperaturas antes e após o efeito de endurecimento secundário para os aços VF-800 e Vanadis 10. Para o aço VND apenas foram escolhidas duas temperaturas, uma menor e outra maior do que a indicada pelo fabricante.

Tabela 12: Condições de revenimento para o aço VND.

\begin{tabular}{c|c|c|c}
\hline & \multicolumn{3}{|c}{ Condições de revenimento } \\
\hline VND & $\begin{array}{c}\text { Dureza } \\
\text { esperada } \\
\text { (HRC) }\end{array}$ & $\begin{array}{c}1^{\circ} \text { Revenimento } \\
\left({ }^{\circ} \mathrm{C}\right)\end{array}$ & $\begin{array}{c}2^{\circ} \text { Revenimento } \\
\left({ }^{\circ} \mathrm{C}\right)\end{array}$ \\
\hline $1^{\circ}$ condição & $59-61$ & & 260 \\
\hline $2^{\circ}$ condição & $56-58$ & \multirow{2}{*}{160} & 300 \\
\hline $3^{\circ}$ condição & $53-55$ & & 370 \\
\hline
\end{tabular}


Tabela 13: Condições de revenimento para o aço Calmax.

\begin{tabular}{|c|c|c|}
\hline & \multicolumn{2}{|c|}{ Condições de revenimento } \\
\hline CALMAX & $\begin{array}{c}\text { Dureza } \\
\text { esperada } \\
\text { (HRC) }\end{array}$ & $\begin{array}{l}\text { 3x Revenimento } \\
\left({ }^{\circ} \mathrm{C}\right)\end{array}$ \\
\hline $1^{\circ}$ condição & $60-62$ & 200 \\
\hline $2^{\circ}$ condição & $57-59$ & 250 \\
\hline $3^{\circ}$ condição & \multirow{4}{*}{$54-56$} & 300 \\
\hline $4^{\circ}$ condição & & 350 \\
\hline $5^{\circ}$ condição & & 400 \\
\hline $6^{\circ}$ condição & & 450 \\
\hline $7^{\circ}$ condição & $52-54$ & 500 \\
\hline
\end{tabular}

Tabela 14: Condições de revenimento para o aço VF-800.

\begin{tabular}{c|c|c|c}
\hline & \multicolumn{3}{|c}{ Condições de revenimento } \\
\hline VF-800 & $\begin{array}{c}\text { Dureza } \\
\text { esperada } \\
\text { (HRC) }\end{array}$ & $\begin{array}{c}1^{\circ} \text { Revenimento } \\
\left({ }^{\circ} \mathrm{C}\right)\end{array}$ & $\begin{array}{c}2^{\circ} \text { Revenimento } \\
\left({ }^{\circ} \mathrm{C}\right)\end{array}$ \\
\cline { 1 - 1 } $1^{\circ}$ condição & $58-60$ & & 300 \\
\cline { 1 - 1 } $2^{\circ}$ condição & $60-62$ & \multirow{2}{*}{530} & 475 \\
\cline { 1 - 1 } \cline { 1 - 1 } $3^{\circ}$ condição & & & 540 \\
\cline { 1 - 1 } $4^{\circ}$ condição & $59-61$ & & 550 \\
\cline { 1 - 1 } $5^{\circ}$ condição & $55-57$ & & 580 \\
\hline
\end{tabular}

Tabela 15: Condições de revenimento para o aço Vanadis 10.

\begin{tabular}{c|c|c}
\hline & \multicolumn{2}{|c}{ Condições de revenimento } \\
\cline { 1 - 1 } Vanadis 10 & $\begin{array}{c}\text { Dureza } \\
\text { esperada } \\
\text { (HRC) }\end{array}$ & 3x Revenimento $\left({ }^{\circ} \mathrm{C}\right)$ \\
\cline { 1 - 1 } $1^{\circ}$ condição & \multirow{2}{*}{$63-65$} & 430 \\
\cline { 1 - 1 } $2^{\circ}$ condição & & 525 \\
\hline $3^{\circ}$ condição & $60-62$ & 550 \\
\hline $3^{\circ}$ condição & $57-59$ & 590 \\
\hline
\end{tabular}

As tabelas 12 a 15 acima se referem aos aços VND, Calmax, VF-800 e Vanadis 10, respectivamente. Os revenimentos foram realizados imediatamente após a têmpera. Os parâmetros marcados em cinza nas tabelas são os sugeridos pelos fabricantes $[16,19,21,42,43]$. 
A figura 15 ilustra os corpos de prova (a) e o local de tratamento térmico (b).
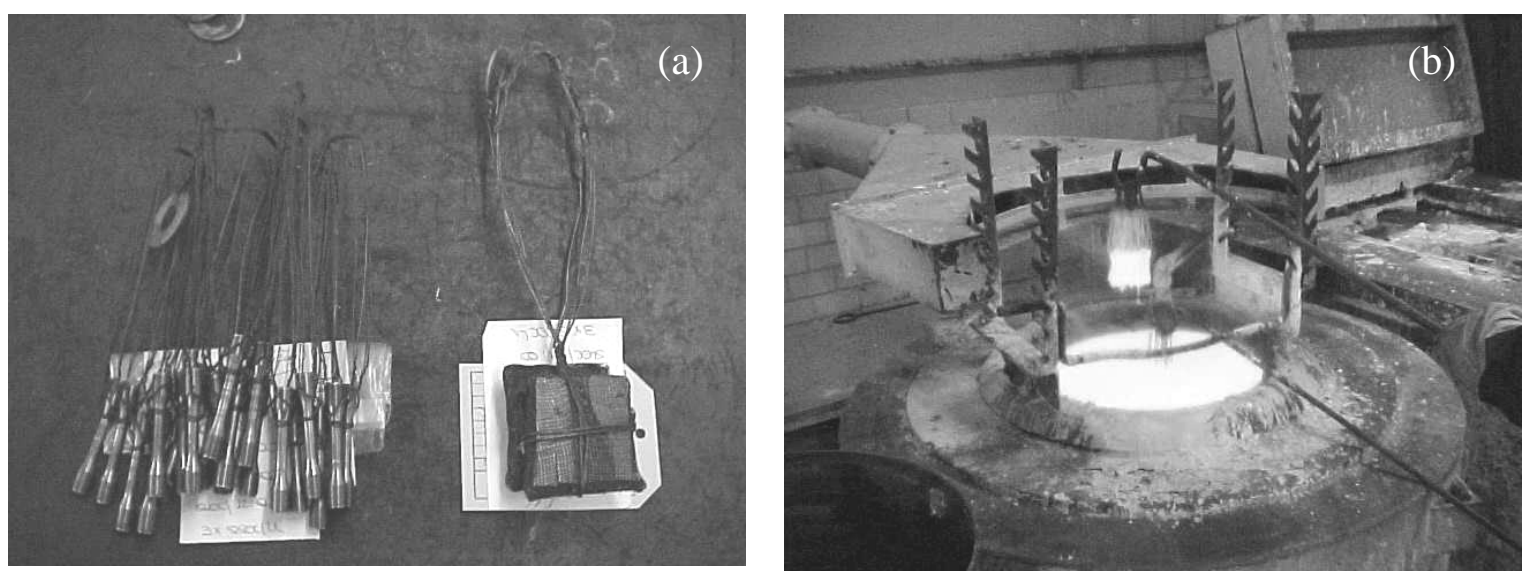

Figura 15: llustra o tratamento térmico dos corpos de prova dos materiais utilizados neste estudo [19].

\subsubsection{Ensaios mecânicos}

O comportamento mecânico dos aços-ferramenta foi avaliado por meio dos ensaios:

1. Ensaios de dureza realizados no material como recebido e após tratamentos térmicos;

2. Ensaios de tração normalizados conforme ASTM E 8M [38], onde foram determinados o limite de escoamento e o limite de resistência;

3. Ensaios de impacto Charpy normalizados conforme ASTM E -23 e NBR 6157[37], onde foi determinada a tenacidade à fratura dos materiais;

4. Ensaios de flexão-4 pontos normalizados conforme ASTM A-438 [39], onde foi avaliada a resistência mecânica.

\subsubsection{Ensaio de Tração}

O ensaio de tração consiste na aplicação de uma força em sentido axial com velocidade controlada num corpo-de-prova de dimensões padronizadas que promove deformações uniformemente distribuídas em todo corpo-de-prova e permite medir satisfatoriamente a resistência do material. O ensaio foi realizado em maquinário TMS Instron - Máquina de Ensaios Universal. A figura 16 ilustra o maquinário utilizado. 


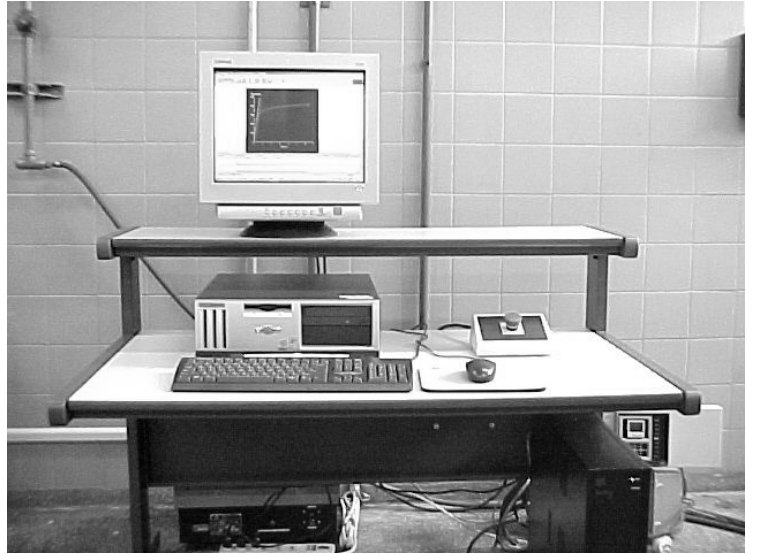

(a)

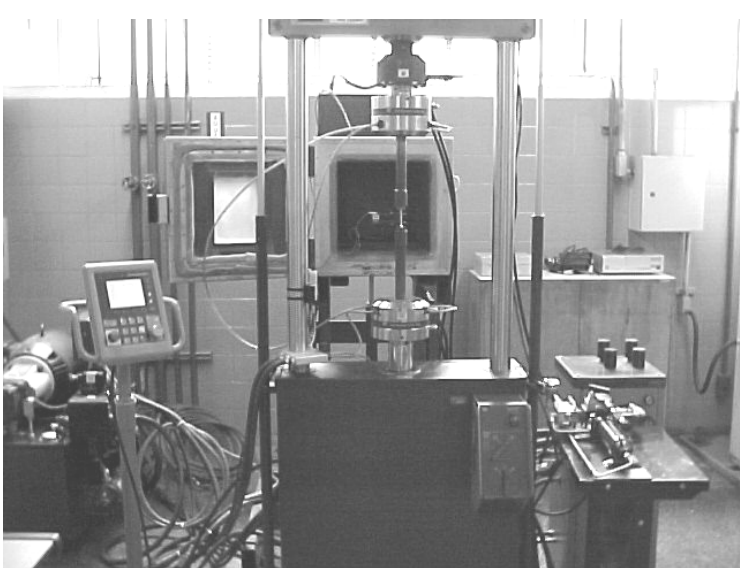

(b)

Figura 16: Ilustra o maquinário utilizado para os testes de tração [19].

\subsubsection{Ensaio de impacto}

O ensaio de impacto Charpy tem grande aceitação devido a sua simplicidade e efetividade na obtenção de valores de energia absorvida pela amostra quando esta é submetida a carregamento dinâmico. Apesar de o corpo-de-prova apresentar na maioria das vezes um entalhe em " $V$ ", tal formato pode apresentar variações, como no caso de materiais com alta fração de partículas frágeis, como os aços-ferramenta alto $\mathrm{C}$ - alto $\mathrm{Cr}$, para os quais se aplicam corpos de prova sem entalhe, devido aos baixos valores de energia absorvida por estes materiais quando solicitados. A velocidade de carregamento em um ensaio de impacto é da ordem de 10 milhões de vezes mais rápidas que a verificada em um ensaio de tração convencional [19]. Tal velocidade é resultado da queda de um martelo pendular com elevado peso de uma altura, o qual se impacta contra uma amostra que se encontra posicionada perpendicularmente à direção do martelo, de forma simétrica.

A fratura ocorrida após o encontro do martelo pendular com a amostra, consome energia do referido martelo a qual é medida pela altura atingida pelo mesmo após o impacto. Os ensaios de impacto Charpy sem entalhe foram realizados em máquina de impacto WPM, martelo 18,750 kgf, padrão RBC (Rede Brasileira de Calibração). As superfícies de fratura obtidas em ensaio de impacto Charpy foram posteriormente observadas em MEV (microscópio eletrônico de varredura). A figura 17 mostra esquematicamente o ensaio de impacto. 


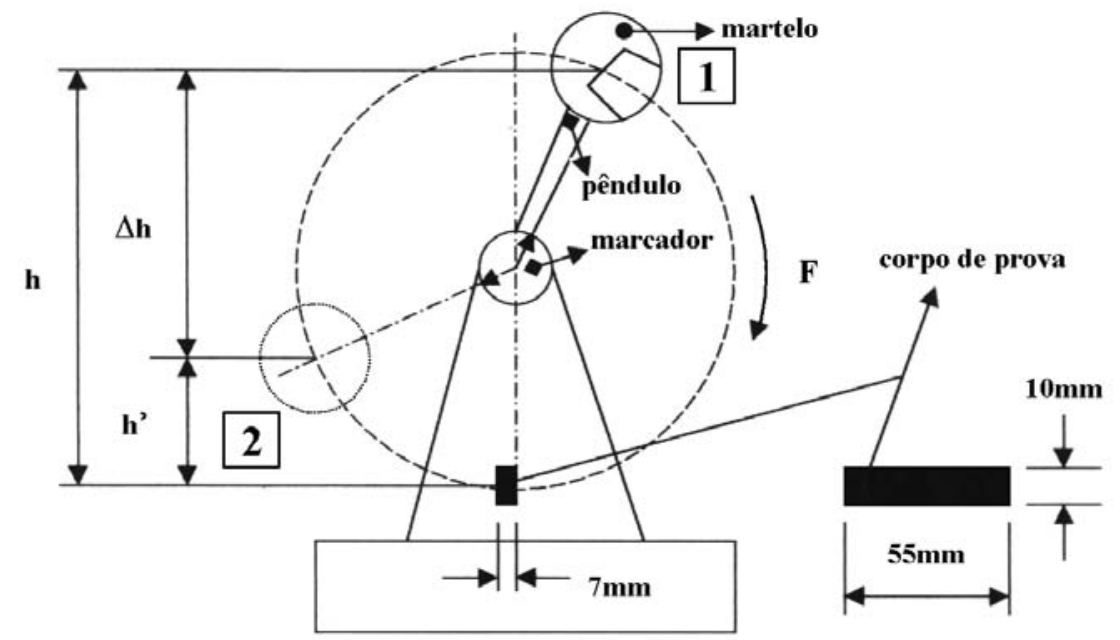

Figura 17: Esquema do ensaio de impacto Charpy sem entalhe [19].

\subsubsection{Ensaio de flexão 4-pontos}

O ensaio de flexão 4-pontos visou obter o módulo de ruptura das amostras. Define-se módulo de ruptura como a tensão de tração máxima suportada em ensaio de flexão por um corpo-de-prova não submetido à deformação plástica. Os ensaios de flexão 4-pontos recomendados para aços-ferramenta para trabalho a frio foram realizados em máquina universal de ensaios Amsler, 30 toneladas, padrão RBC (Rede Brasileira de Calibração). A figura 18 mostra dispositivo utilizado para a realização do ensaio.

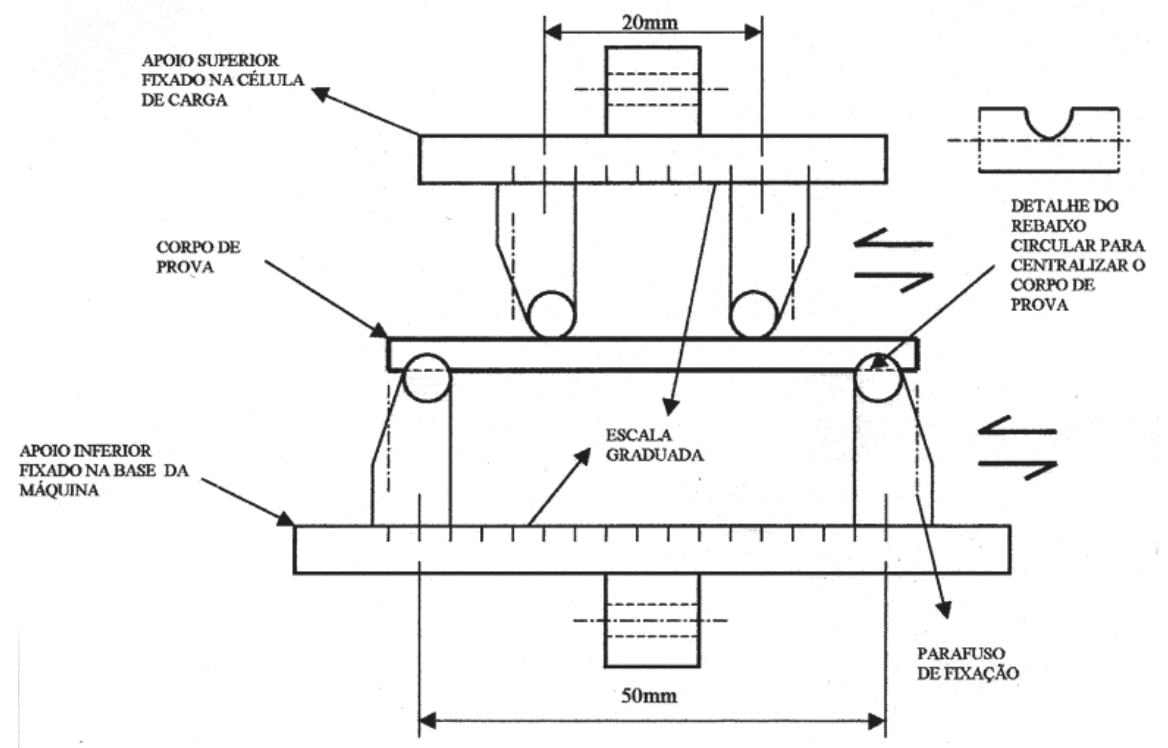

Figura 18: Esquema do dispositivo usado para realização do ensaio de flexão 4-pontos [19]. 
4.5.3.4 Ensaios de dureza

As medidas de dureza em escala Brinell e Rockwell $C$ foram realizadas conforme norma técnica aplicável [44,45].

\subsubsection{Caracterização microestrutural}

Foram utilizadas técnicas de microscopia óptica (MO) e microscopia eletrônica de varredura (MEV) acoplada a análises químicas de micro-regiões por energia dispersiva (EDS) para avaliação da microestrutura dos materiais como recebido, bruto de têmpera e após revenimento. Foi observada ainda a superfície de fratura dos corpos-de-prova provenientes do teste de impacto Charpy $[46,47]$. 


\section{RESULTADOS E DISCUSSÃO}

\subsection{Caracterização dos aços no estado como recebido (recozido)}

\subsubsection{Composição química}

A composição química dos aços, obtida por fluorescência de raios-X está apresentada na tabela 16.

Tabela 16: Composição química dos aços em estudo (\% peso).

\begin{tabular}{|c|c|c|c|c|c|c|c|c|l|}
\hline \multirow{2}{*}{ Liga } & Elementos & $\mathrm{C}$ & $\mathrm{Cr}$ & $\mathrm{Si}$ & $\mathrm{V}$ & $\mathrm{W}$ & $\mathrm{Mn}$ & $\mathrm{Mo}$ & $\mathrm{Fe}$ \\
\hline \multirow{2}{*}{ VND } & Especificado & 0,95 & 0,50 & 0,25 & 0,12 & 0,50 & 1,25 & - & balanço \\
\cline { 2 - 10 } & Encontrado & 0,95 & 0,59 & 0,36 & 0,10 & 0,37 & 1,20 & 0,11 & balanço \\
\hline \multirow{2}{*}{ CALMAX } & Especificado & 0,60 & 4,50 & 0,35 & 0,20 & - & 0,80 & 0,50 & balanço \\
\cline { 2 - 10 } & Encontrado & 0,59 & 4,43 & 0,52 & 0,25 & - & 0,69 & 0,47 & balanço \\
\hline \multirow{2}{*}{\begin{tabular}{c} 
VF-800 \\
\cline { 2 - 10 }
\end{tabular}} & Especificado & 0,85 & 8,00 & 0,90 & 0,50 & - & 0,40 & 2,00 & balanço \\
\cline { 2 - 10 } & Encontrado & 0,82 & 7,40 & 0,86 & 0,37 & - & 0,37 & 1,94 & balanço \\
\cline { 2 - 10 } & Especificado & 2,90 & 8,00 & 0,50 & 9,80 & - & 0,50 & 1,50 & balanço \\
\hline
\end{tabular}

Os valores de composição química obtidos se encontram conforme o especificado para as ligas em estudo, segundo dados do fabricante $[16,19,21]$. 


\subsubsection{Dureza}

Os aços no estado recozido apresentaram os valores de dureza mostrados na tabela 17.

Tabela 17: Valores de dureza obtidos nos aços em estudo - estado recozido.

\begin{tabular}{|c|c|c|c|c|}
\cline { 2 - 5 } \multicolumn{1}{c|}{} & \multicolumn{4}{c|}{ Dureza (HB) } \\
\hline Secção & Vanadis 10 & VF-800 & VND & Calmax \\
\hline Longitudinal & $261 \pm 8$ & $220 \pm 7$ & $203 \pm 3$ & $214 \pm 3$ \\
\hline Transversal & $264 \pm 10$ & $223 \pm 7$ & $210 \pm 5$ & $209 \pm 4$ \\
\hline
\end{tabular}

$\mathrm{Na}$ figura 19 estão apresentados os valores de dureza obtidos para os aços no estado recozido. As medições foram feitas nas secções transversal e longitudinal. Os valores são próximos entre as duas secções do mesmo aço, indicando possível isotropia das ligas.

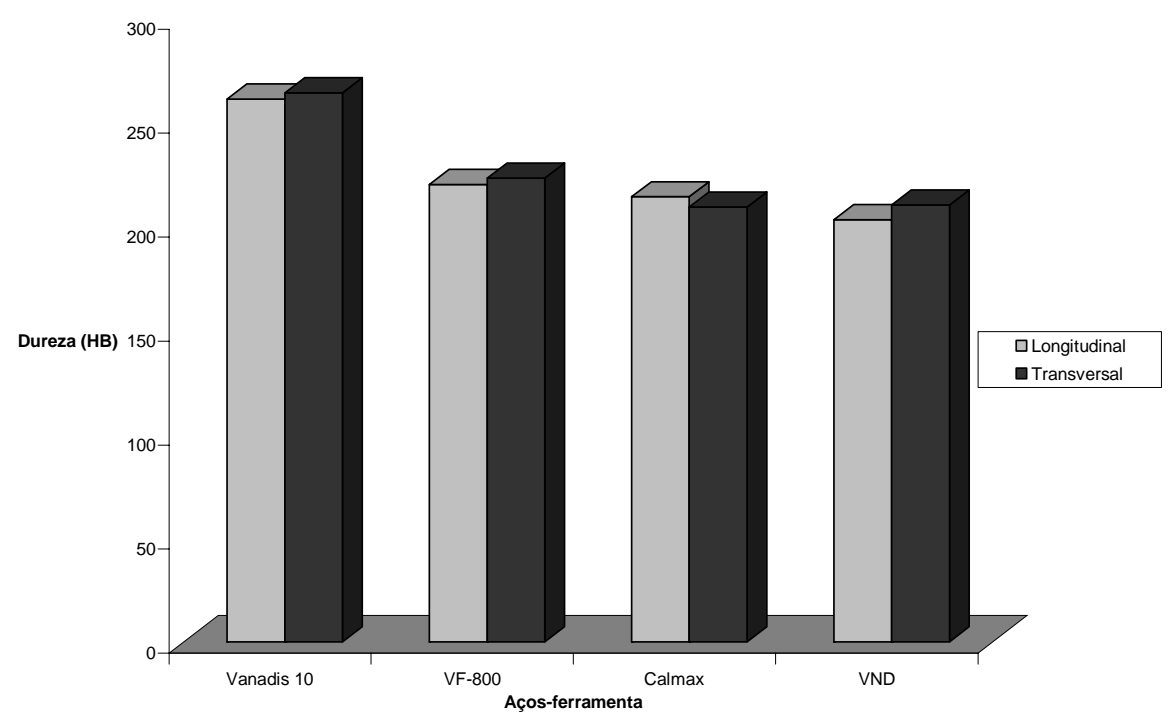

Figura 19: Valores de dureza para os aços em estudo - estado recozido.

\subsubsection{Microestrutura}

Com exceção do aço Vanadis 10, os aços-ferramenta em estudo apresentam baixos teores de $\mathrm{V}$, além de teor moderado de Mo, características estas que os tornam similares. A similaridade também está no tocante aos elementos $\mathrm{C}$ e $\mathrm{Cr}$, além da 
presença considerável de pelo menos um elemento de liga formador de carboneto, o que permite uma analogia entre as microestruturas encontradas no estado recozido. Nas figuras a seguir estão apresentadas as micrografias dos aços em estudo, nas secções tranversal e longitudinal, próxima ao núcleo e próxima a superfície. Em alguns casos foram observadas secções situadas à distância de $1 / 2$ do raio.

A microestrutura dos aços VND e Calmax é constituída de carbonetos secundários finos (regiões claras) dispersos em matriz ferrrítica (região escura). Não foram observadas evidências da presença de carbonetos primários nesses aços nesta condição recozida, nem diferenças relevantes entre as microestruturas das regiões de superfície e centro, bem como entre as secções longitudinal e transversal do material.

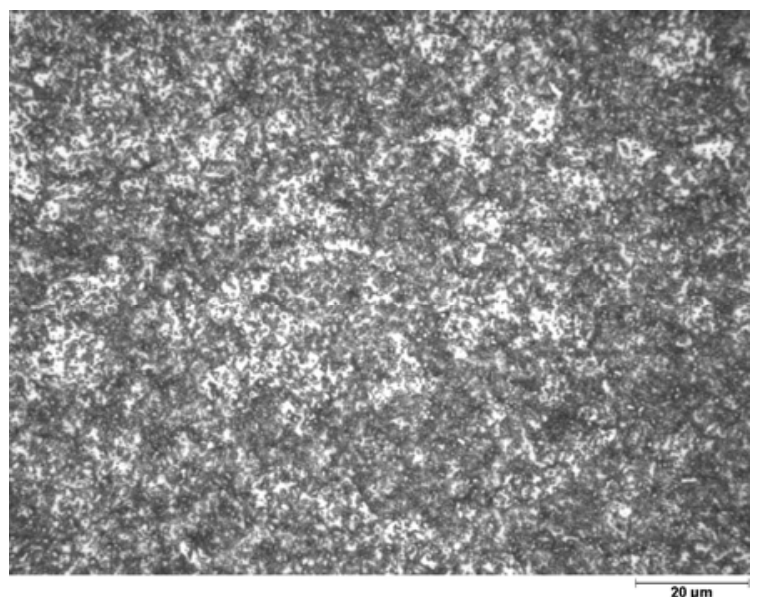

(a)

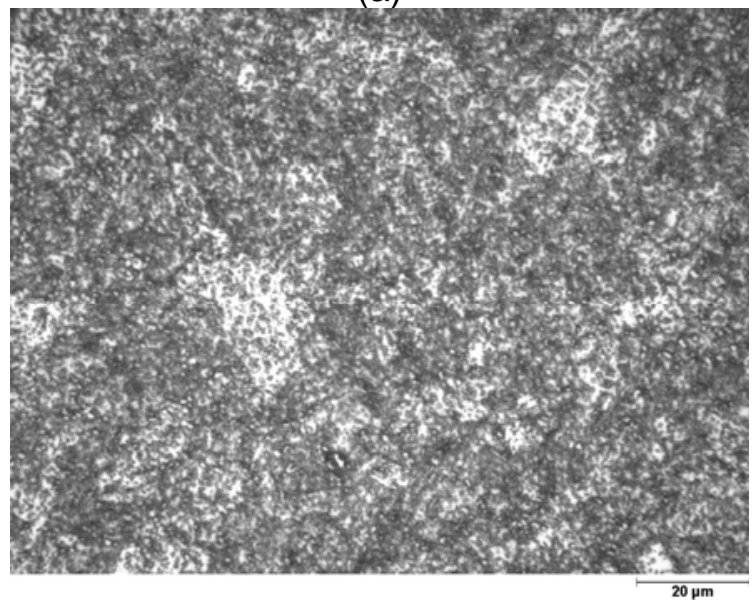

(c)

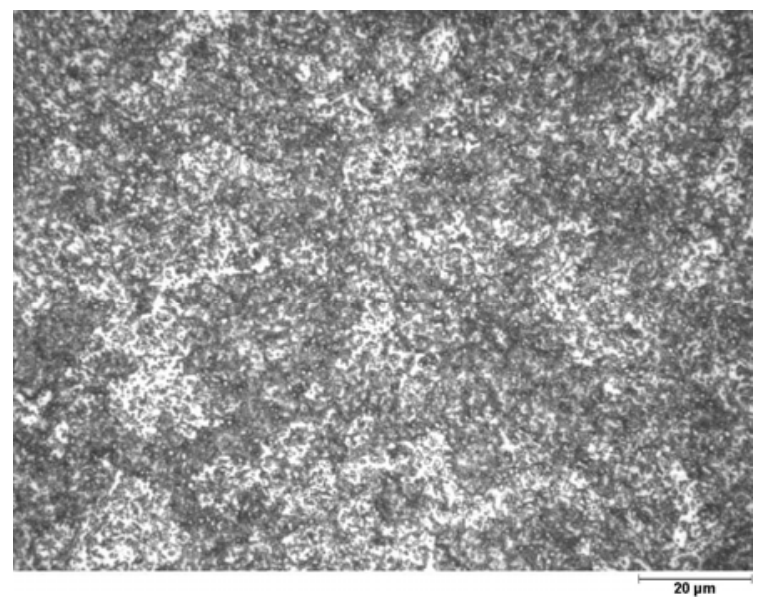

(b)

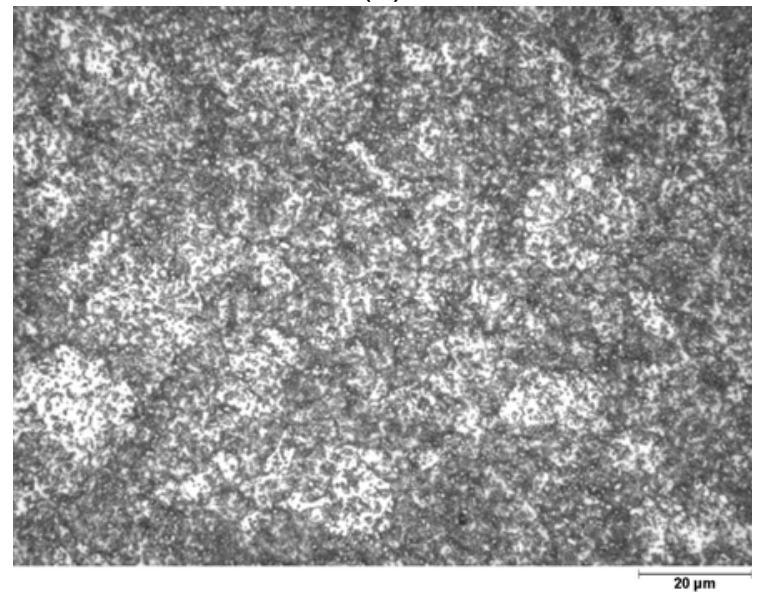

(d)

Figura 20: Microestrutura do aço VND como recebido. (a) secção longitudinal região de superfície: (b) secção longitudinal região do núcleo; (c) secção transversal região de superfície; (d) secção transversal região de núcleo. 


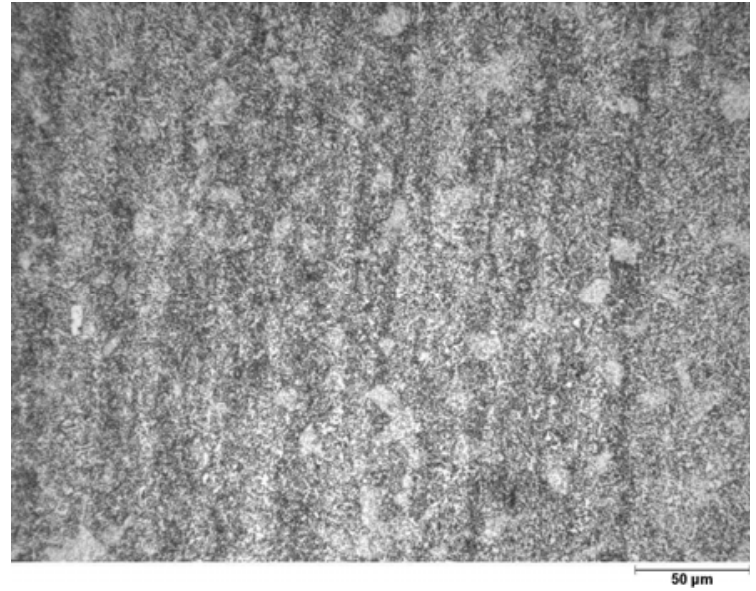

(a)

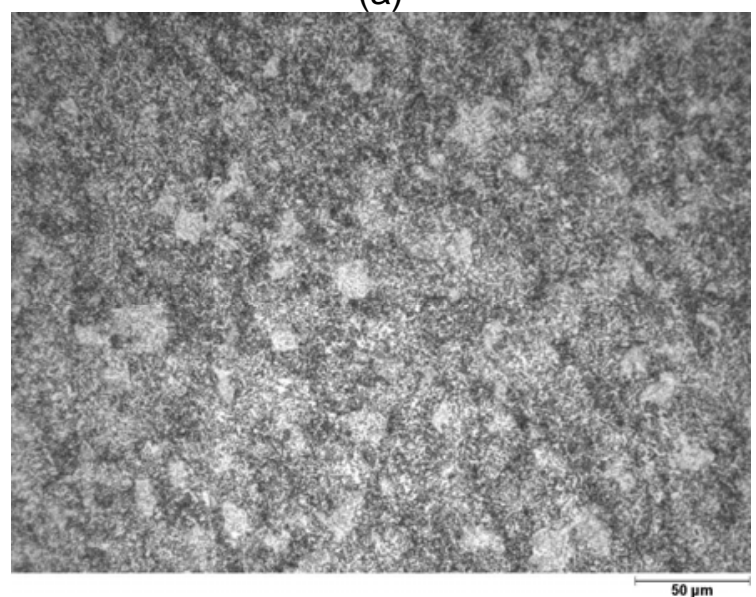

(c)

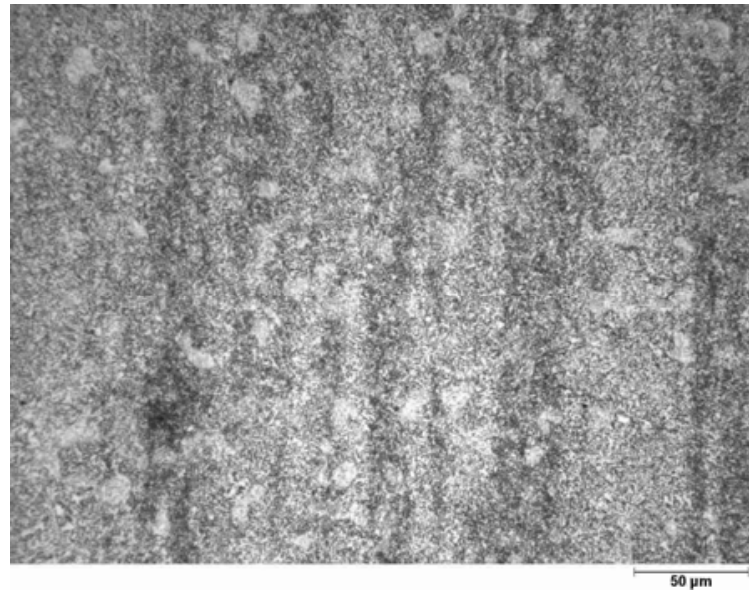

(b)

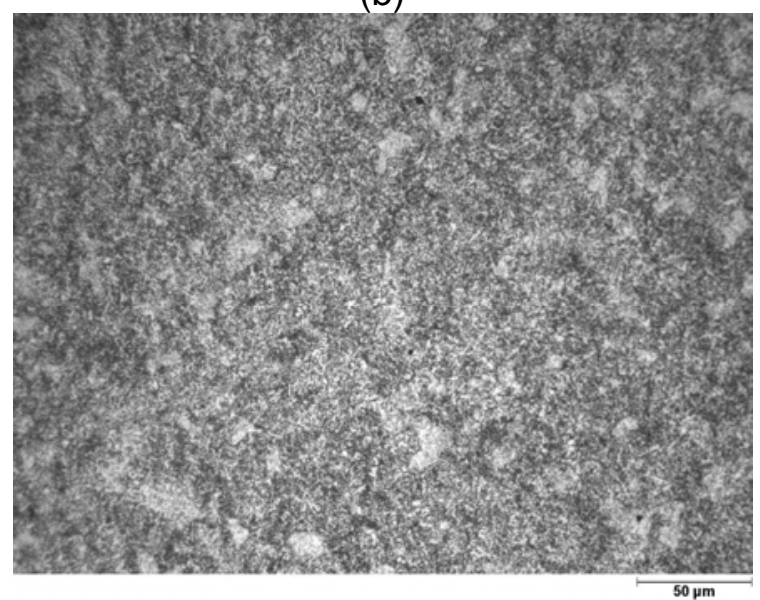

(d)

Figura 21: Microestrutura do aço Calmax como recebido. (a) secção longitudinal região de superfície: (b) secção longitudinal região do núcleo; (c) secção transversal região de superfície; (d) secção transversal região de núcleo.

A microestrutura dos aços VF-800 e Vanadis 10 é constituída de visíveis carbonetos primários e, no caso do VF-800, também os secundários. Comparando-se as micrografias obtidas nas regiões de borda e centro do aço VF-800 foram observadas diferenças microestruturais significativas. O padrão de microestrutura está associado às condições de solidificação do lingote, com maior taxa de extração de calor em regiões próximas à superfície. Assim, os carbonetos primários apresentam dimensão menor nas regiões mais próximas à superfície. O aço Vanadis 10 apresenta carbonetos primários finos bem distribuídos, devido ao próprio processo de fabricação (M/P). Não foram observadas diferenças relevantes entre as microestruturas das regiões de superfície e centro, nem entre as secções longitudinal e transversal do material. 


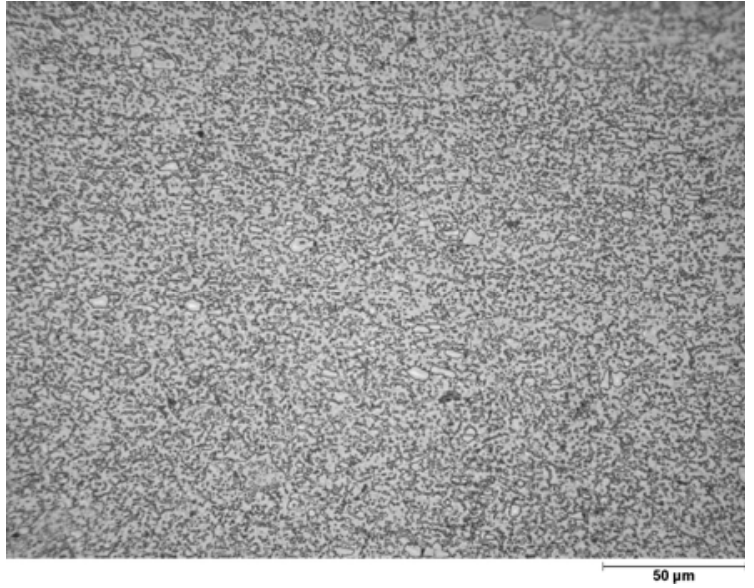

(a)

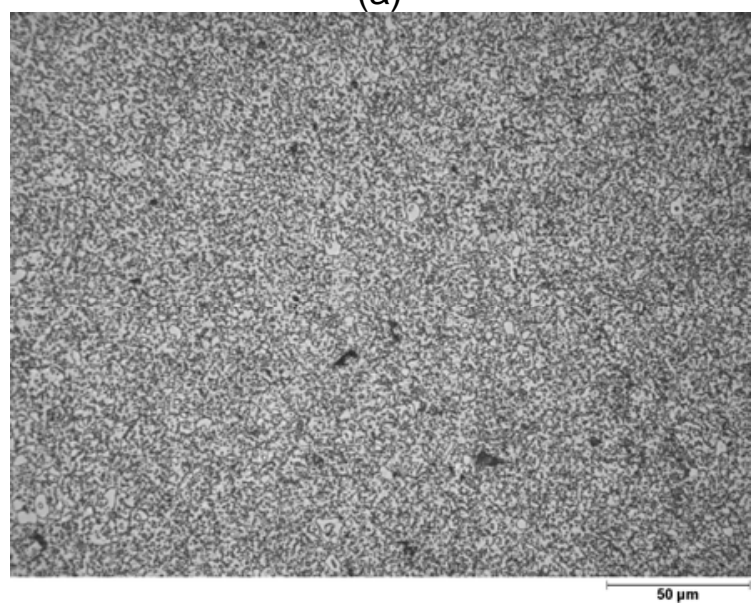

(c)

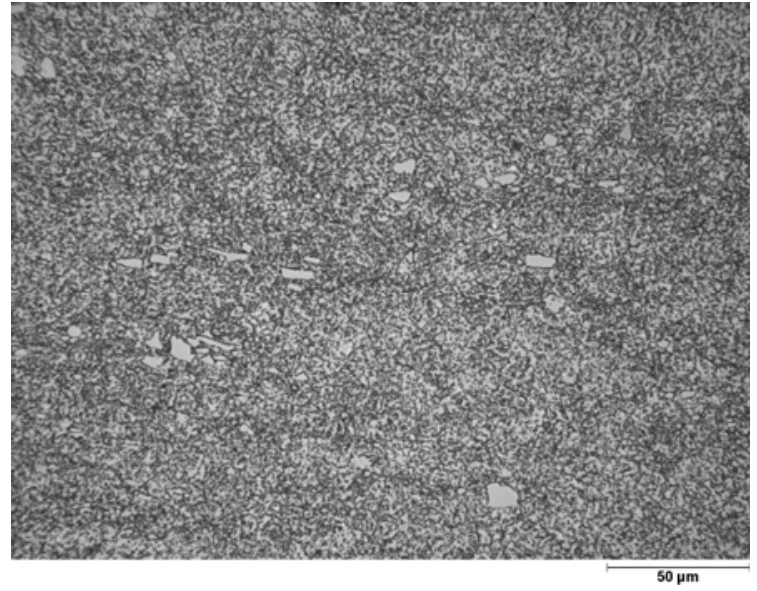

(b)

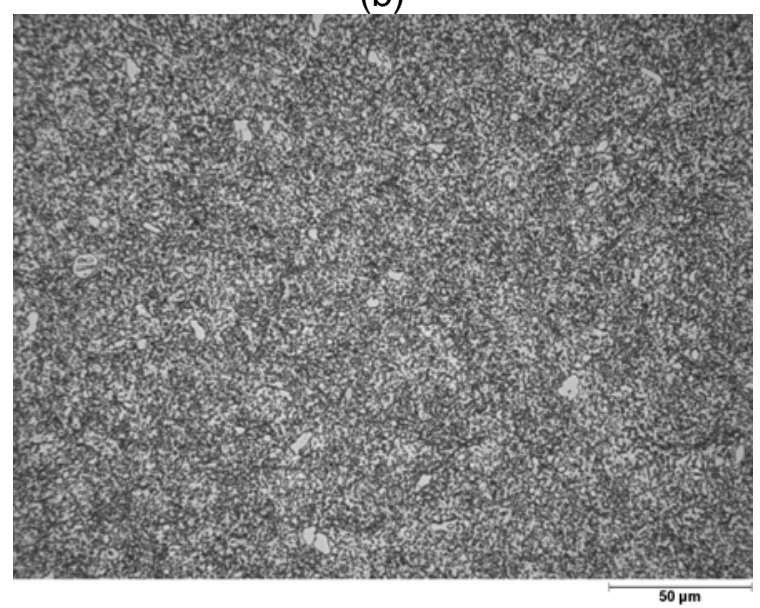

(d)

Figura 22: Microestrutura do aço VF-800 como recebido. (a) secção longitudinal região de superfície: (b) secção longitudinal região do núcleo; (c) secção transversal região de superfície; (d) secção transversal região de núcleo.

Na figura 23 observa-se a microestrutura do aço VF-800 como recebido, realizada numa região de $1 / 2$ de raio. Observa-se a matriz ferrítica com poucos carbonetos primários alinhados. As figuras 24 a 26 são referentes ao aço Vanadis 10 . Observa-se a matriz ferrrítica com finos carbonetos homogeneamente dispersos. 


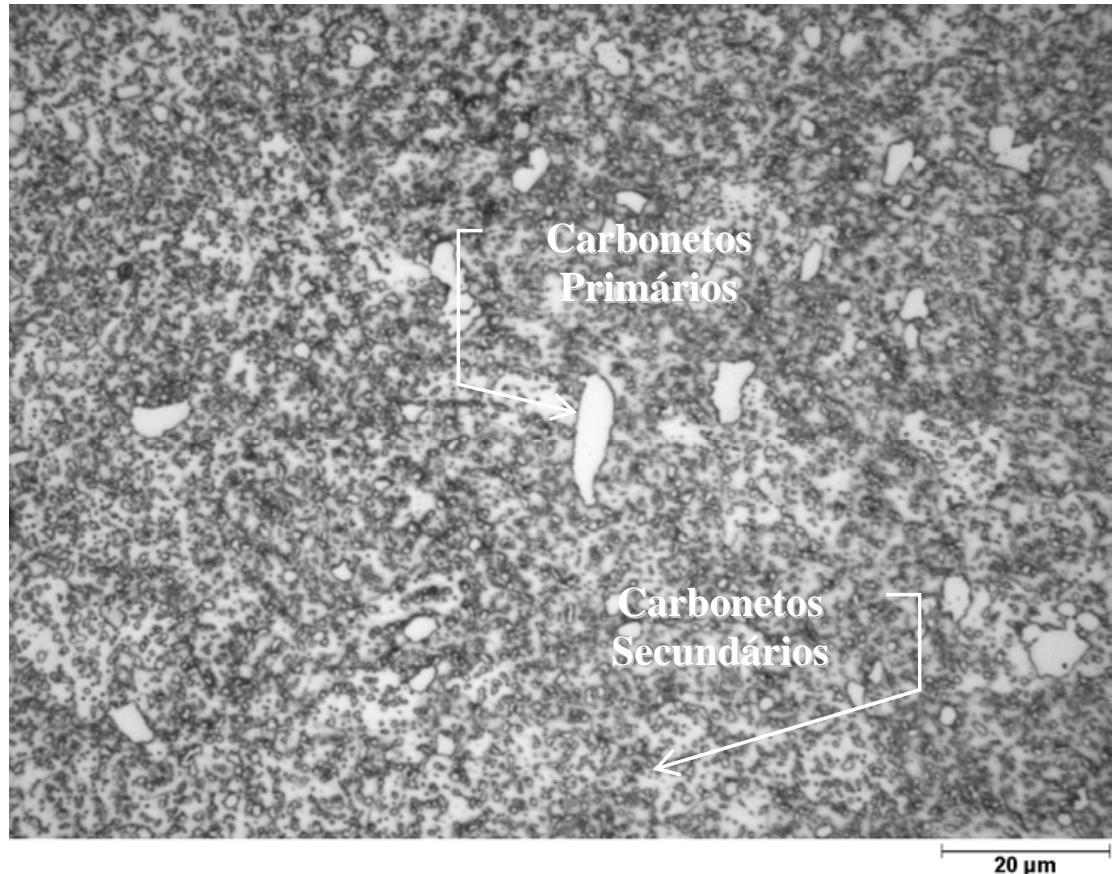

Figura 23: Secção transversal região de 1/2 do raio do aço VF-800 como recebido.

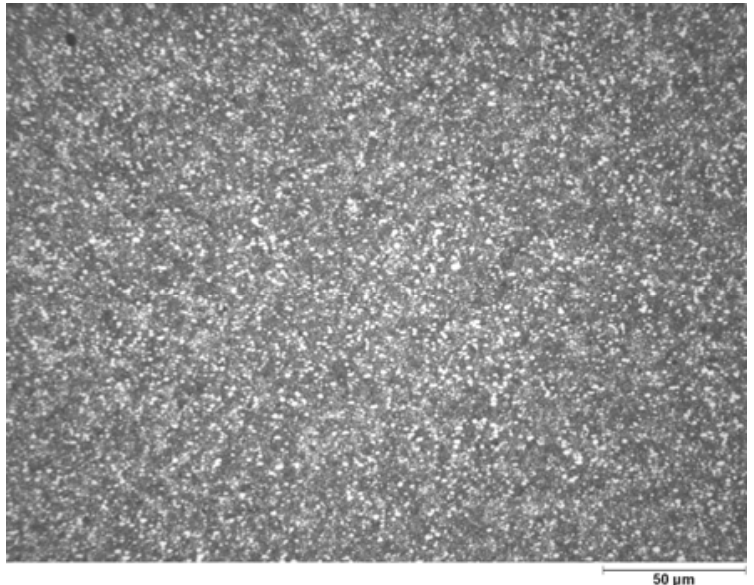

(a)

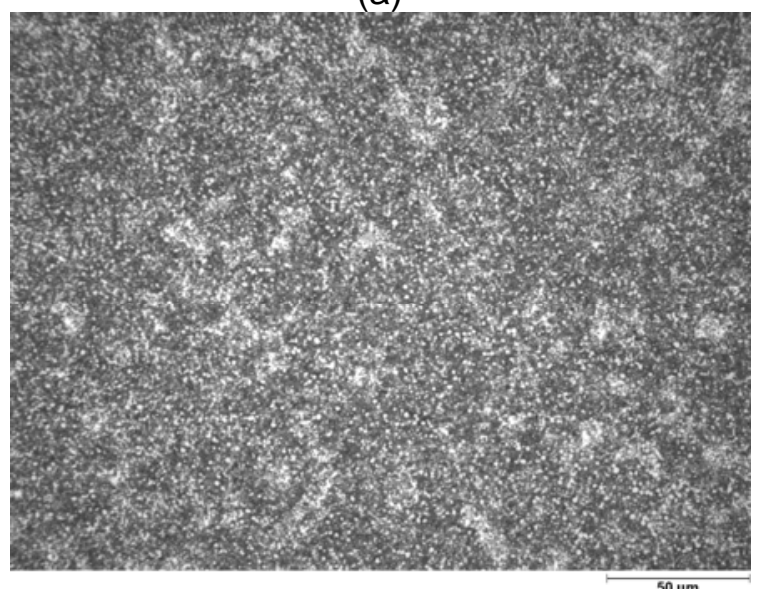

(c)

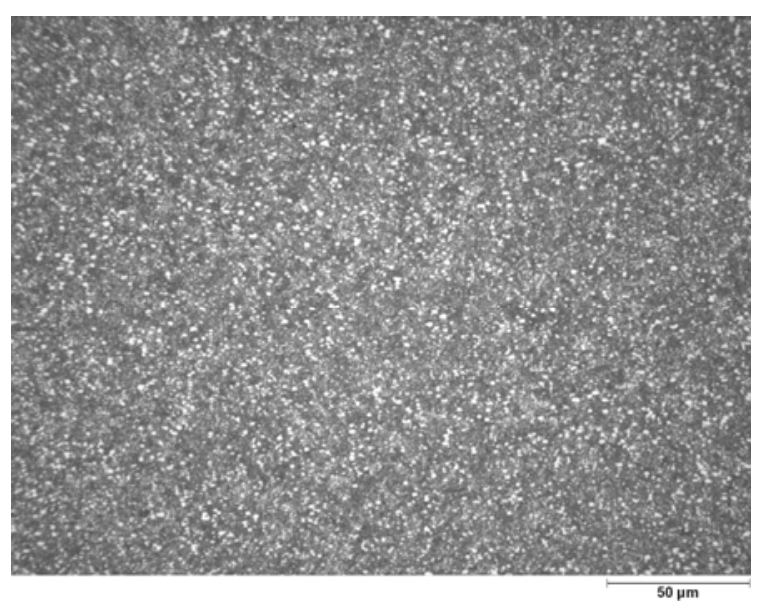

(b)

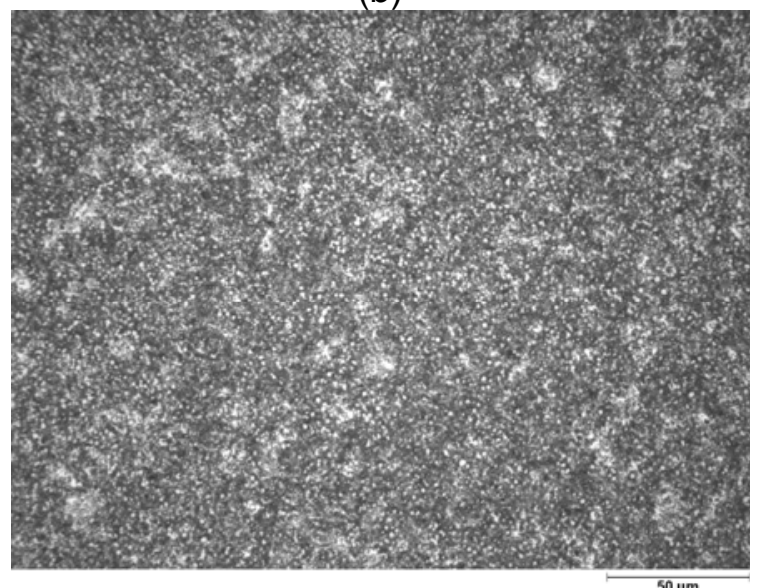

(d)

Figura 24: Microestrutura do aço Vanadis 10 como recebido. (a) secção longitudinal região de superfície: (b) secção longitudinal região do núcleo; (c) secção transversal região de superfície; (d) secção transversal região de núcleo. 


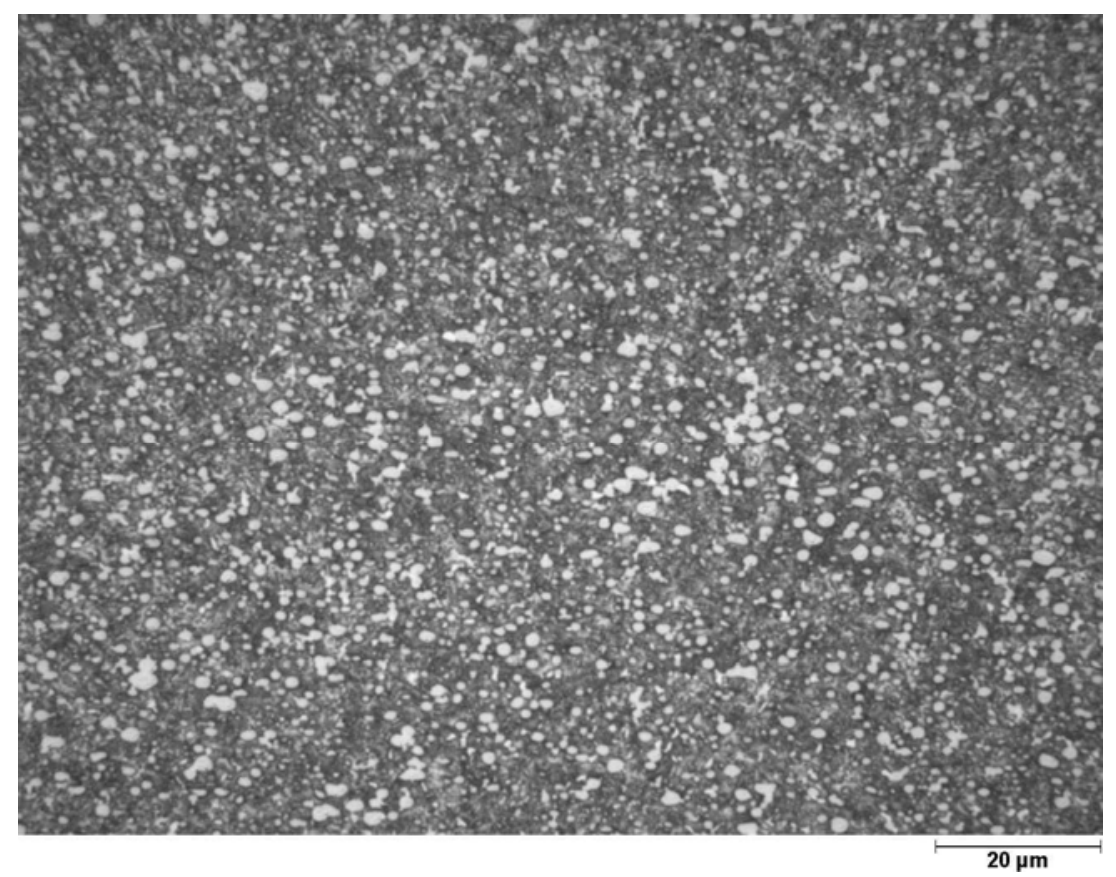

Figura 25: Secção longitudinal região de $1 / 22$ do raio do aço Vanadis 10 como recebido.

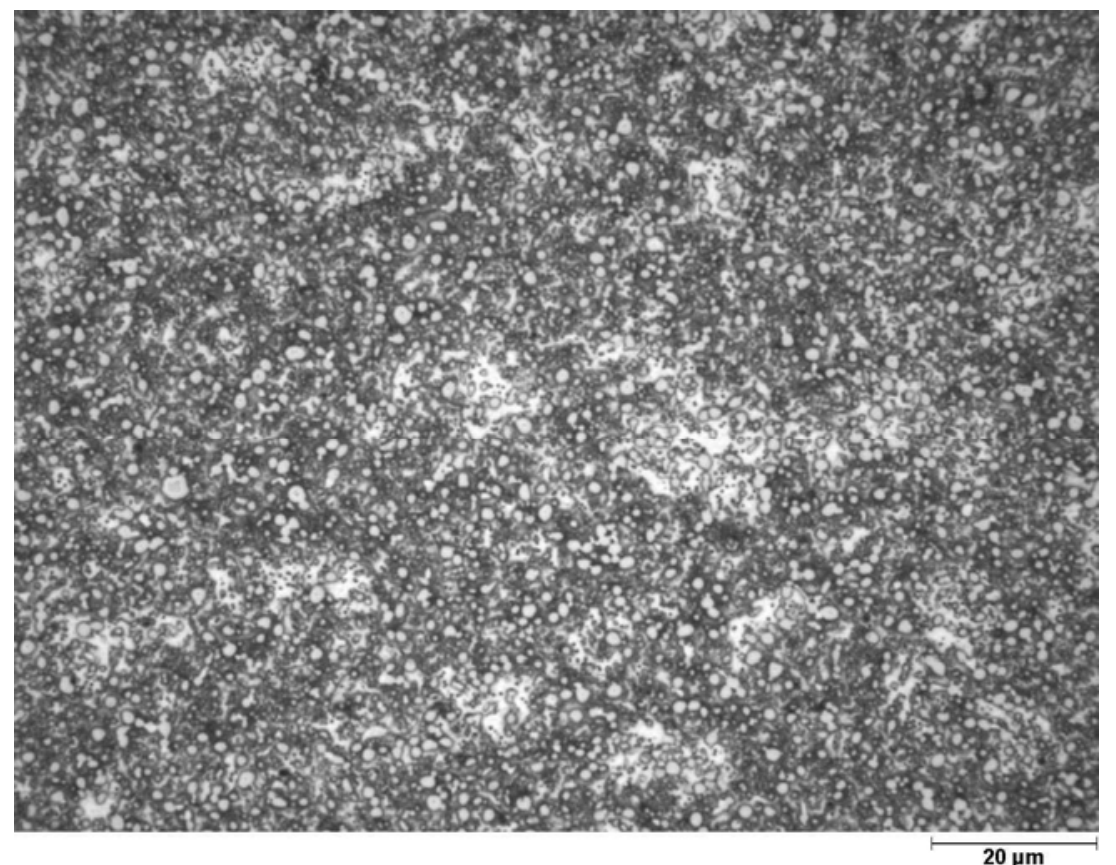

Figura 26: Secção transversal região de 1/2 do raio do aço Vanadis 10 como recebido.

As fotomicrografias dos aços em estado recozido ilustram, de uma forma geral, microestruturas finas, constituídas por carbonetos de recozimento em matriz ferrítica. Não houve evidências de carbonetos primários nas micrografias apresentadas dos aços Calmax e VND, porém os aços VF-800 e Vanadis 10 mostram ocorrência significativa, considerando a particularidade do aço Vanadis 10 ser produzido por metalurgia do pó, e, portanto, apresentar carbonetos "primários" finos e de melhor distribuição. O aço VF-800 
apresenta baixa fração volumétrica de carbonetos primários, se comparado com uma típica microestrutura bruta de fusão do AISI -D2. [19, 46,47].

Não há diferenças relevantes entre as regiões de superfície e núcleo, bem como nas secções longitudinal e transversal dos aços-ferramenta Calmax, VND e Vanadis 10, pois nos dois primeiros há apenas carbonetos de recozimento finos e diminutos dispersos de forma homogênea na matriz ferrítica e o último, como já citado, é produzido por metalurgia do pó, processo que possilibita grande controle microestrutural, e obtenção de uma microestrutura homogênea, com carbonetos esferoidizados e de tamanho reduzido, justificando a igualdade microestrutural das distintas regiões de superfície e núcleo nas secções transversal e longitudinal (isotropia). Já o aço VF-800 apresenta na região do núcleo carbonetos mais grosseiros, com distribuição mais espaçada e pouco uniforme em relação à região da superfície. Como nos aços da série AISI -D2, este padrão de microestrutura está associado às condições de solidificação nos lingotes, devido à alta taxa de extração de calor em regiões próximas à superfície, comparando-se às próximas ao núcleo. Outro fator a ser considerado é a macrosegregação advinda, em geral, da menor solubilidade de elementos de liga no sólido em relação ao líquido, promovendo um enriquecimento de elementos de liga nas regiões de final de solidificação.

\subsection{Caracterização dos aços após tratamentos térmicos}

No estado temperado os aços-ferramenta são constituídos de martensita, austenita retida e carbonetos. Os aços VF-800 e Vanadis 10 apresentam maior fração de carbonetos dispersos na matriz martensítica devido ao maior teor de elementos de liga formadores de carbonetos.

\subsubsection{Aço VND no estado temperado e revenido}

$\mathrm{Na}$ figura 27 está apresentada a secção transversal do aço VND somente temperado, e temperado e revenido nas temperaturas de 260,300 e $370^{\circ} \mathrm{C}$. Observa-se em todos os casos a matriz martensítica contendo finos precipitados de carbonetos secundários, remanescentes da austenitização que precede a têmpera. As observações por MO não revelaram diferenças significativas no tamanho e distribuição dos carbonetos secundários. 


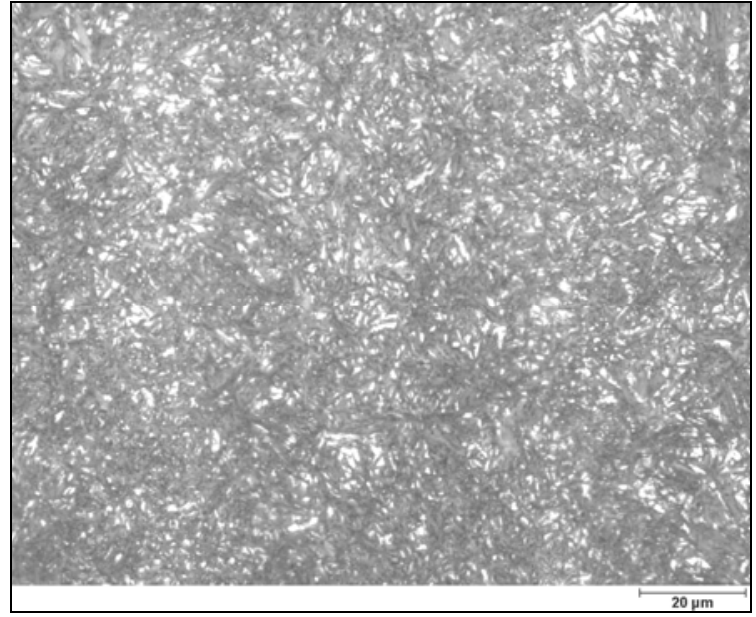

(a)

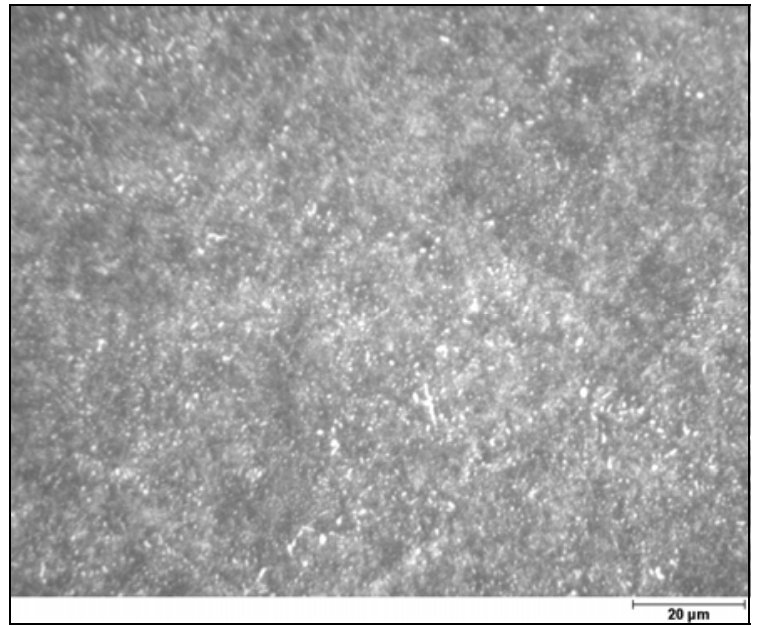

(c)

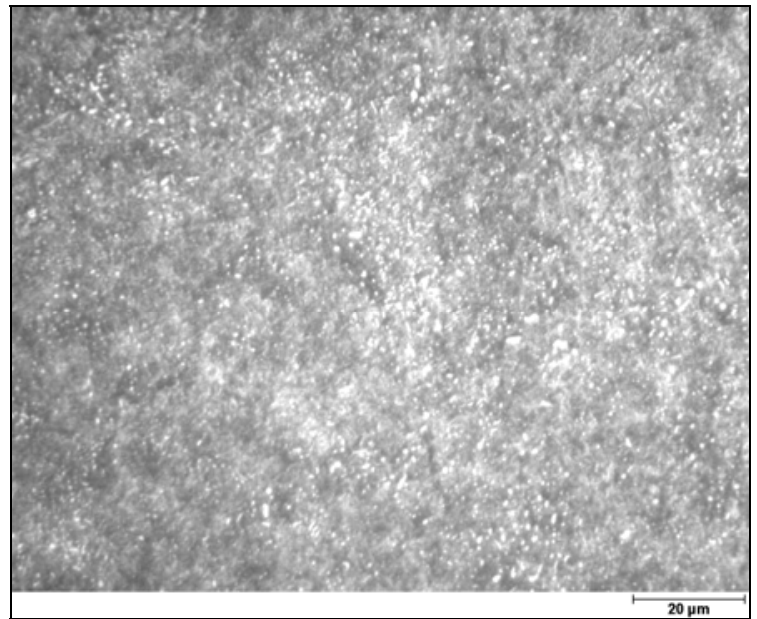

(b)

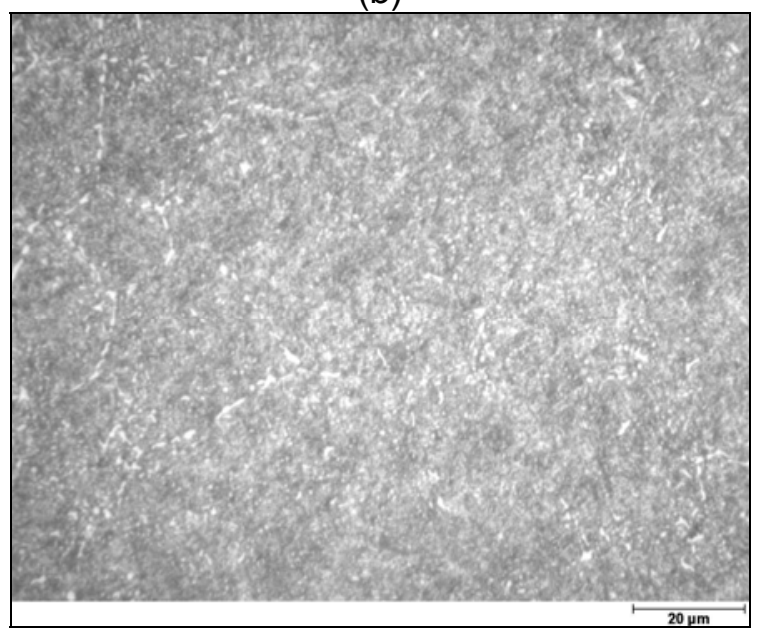

(d)

Figura 27: Secção transversal do aço VND. Ataque Nital 3\%. (a) Somente temperado; (b) Temperado e revenido a $260^{\circ} \mathrm{C}$; (c) Temperado e revenido a $300^{\circ} \mathrm{C}$; (c) Temperado e revenido a $370^{\circ} \mathrm{C}$.

Na figura 28a está apresentada a microestrutura do aço VND apenas temperado. Observa-se a matriz martensítica, com a presença de austenita retida (seta branca), com pouca precipitação de carbonetos. A figura $28 \mathrm{~b}$ é o mesmo material, temperado e revenido. Observa-se a presença de precipitados (seta preta), que análises via EDS indicaram ser ricos em $W, C r$ e $V$, sugerindo serem carbonetos do tipo $M_{3} C$, em matriz de martensita revenida. A presença do ferro na figura $28 \mathrm{c}$ pode estar relacionada à composição química do carboneto, não se descartando a possibilidade do efeito da matriz, pois a partícula analisada é pequena e o volume excitado pelo feixe eletrônico pode ter atingido a matriz. A figura $28 d$ é o EDS da matriz ferrosa, não indicando a presença marcante de outros elementos. 


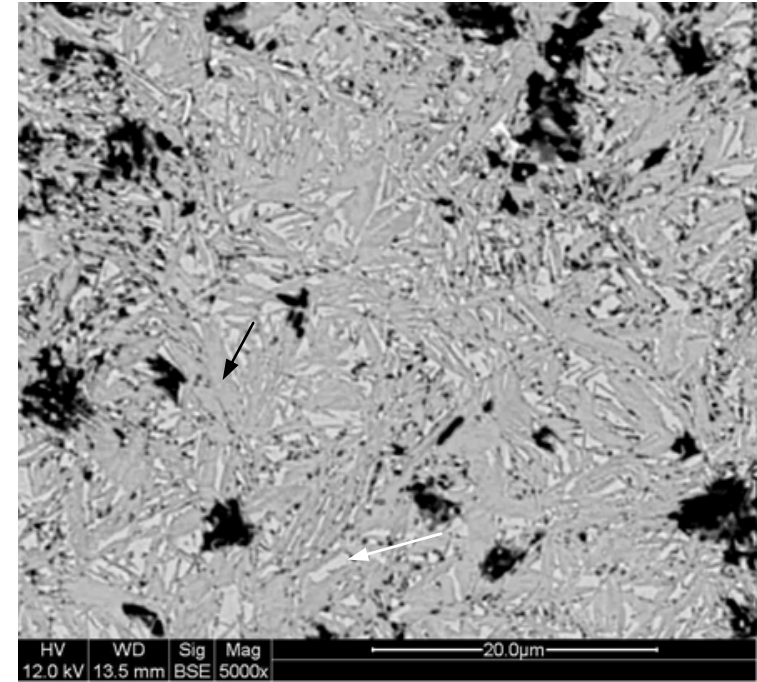

(a)

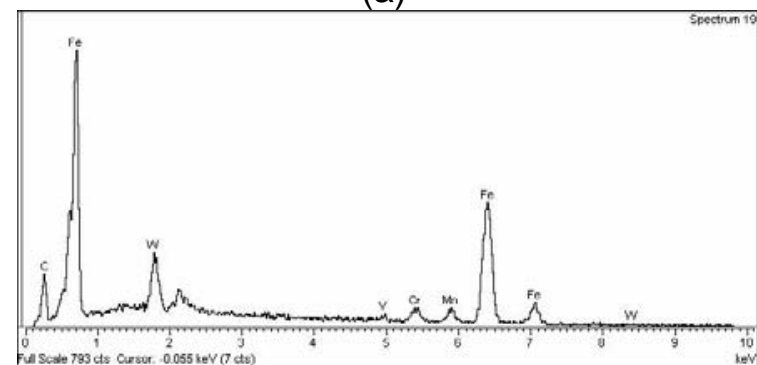

(c)

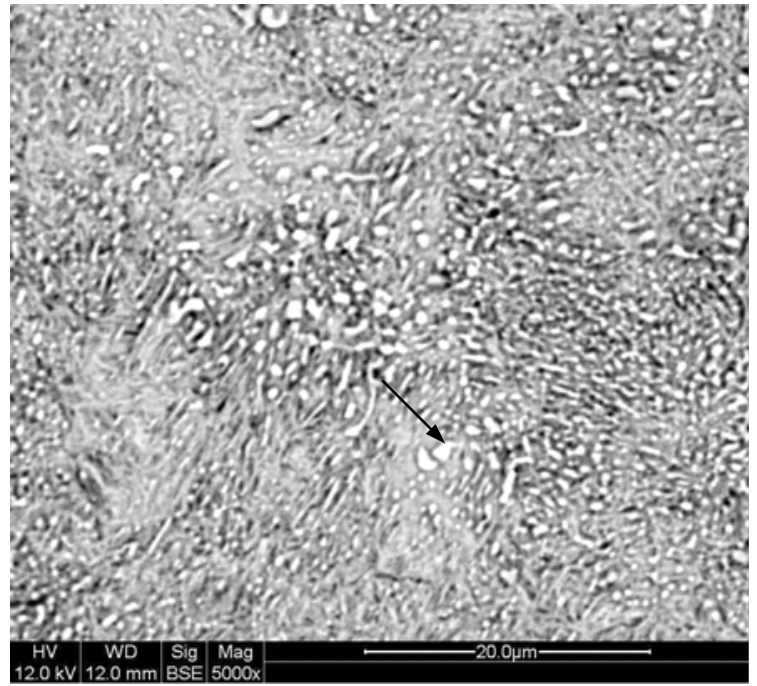

(b)

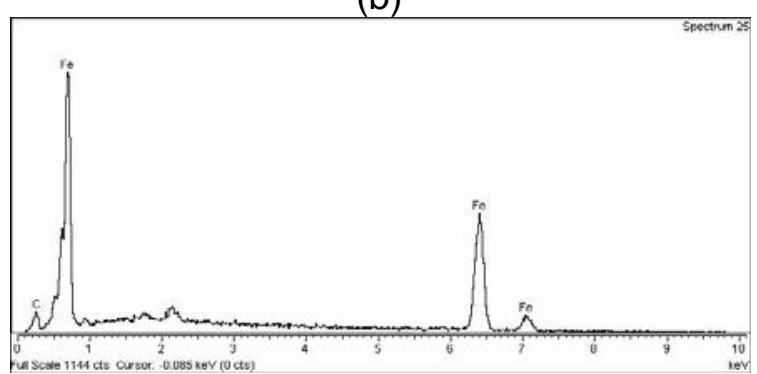

(d)

Figura 28: (a) Secção transversal do aço VND somente temperado. Ataque Marble; (b) Secção transversal VND temperado e revenido a $300^{\circ} \mathrm{C}$; (c) EDS de carbonetos; (d) EDS da matriz.

Na figura 29 estão apresentados os valores de dureza obtidos para o aço VND após revenimento em várias temperaturas. A dureza indicada pela curva do fabricante apresenta baixo desvio em relação à curva de dureza obtida nos tratamentos térmicos realizados. Observa-se que a dureza decresce com o aumento da temperatura de revenimento.

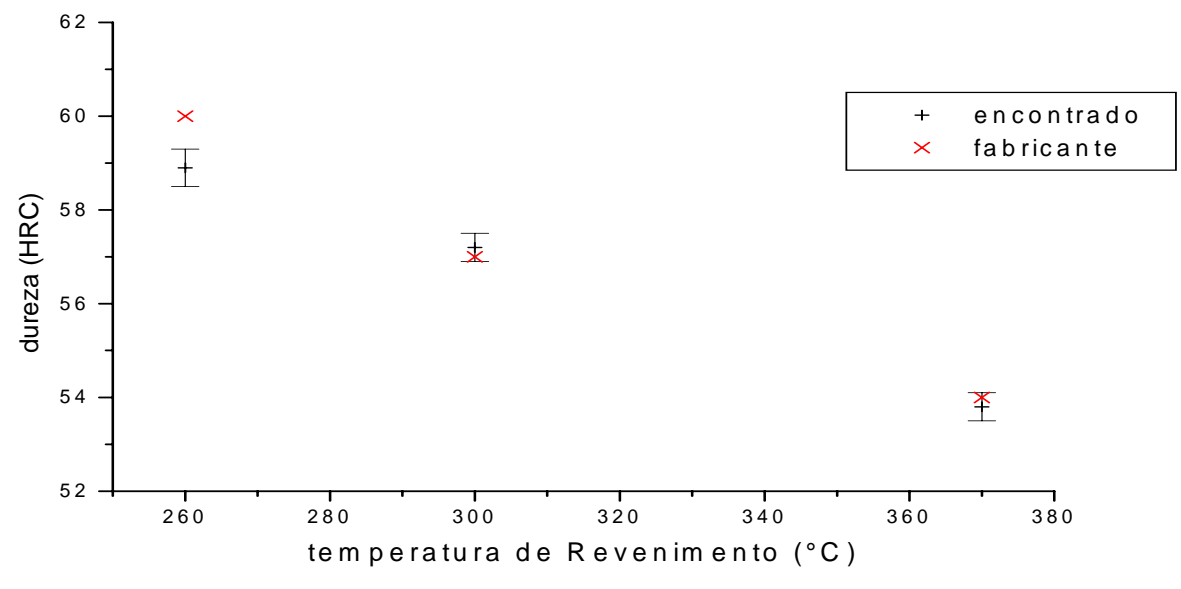

Figura 29: Dureza em função da temperatura de revenimento para o aço VND. 
$\mathrm{Na}$ figura 30 estão apresentados os valores de limite de resistência obtidos nos testes de tração para o aço VND. Observa-se que o limite de resistência aumenta com o aumento da dureza, apresentando melhor resultado na temperatura de revenimento de $260^{\circ} \mathrm{C}(58,9 \mathrm{HRC})$.

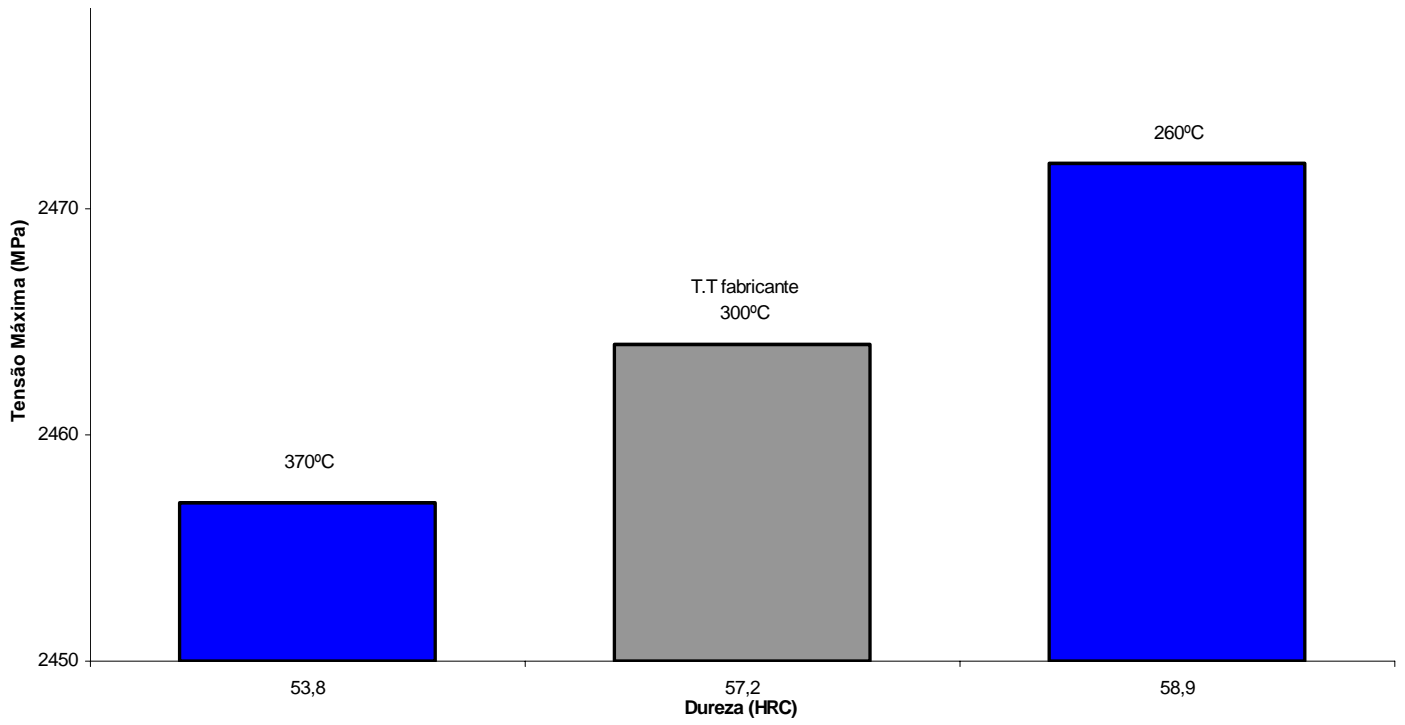

Figura 30: Limite de resistência em função da dureza para o aço VND.

Na figura 31 estão apresentados os valores de tenacidade obtidos em ensaios Charpy em função da dureza. Observa-se que a tenacidade decresce com o aumento da dureza, apresentando melhor resultado na temperatura de revenimento de $370^{\circ} \mathrm{C}(53,8$ HRC).

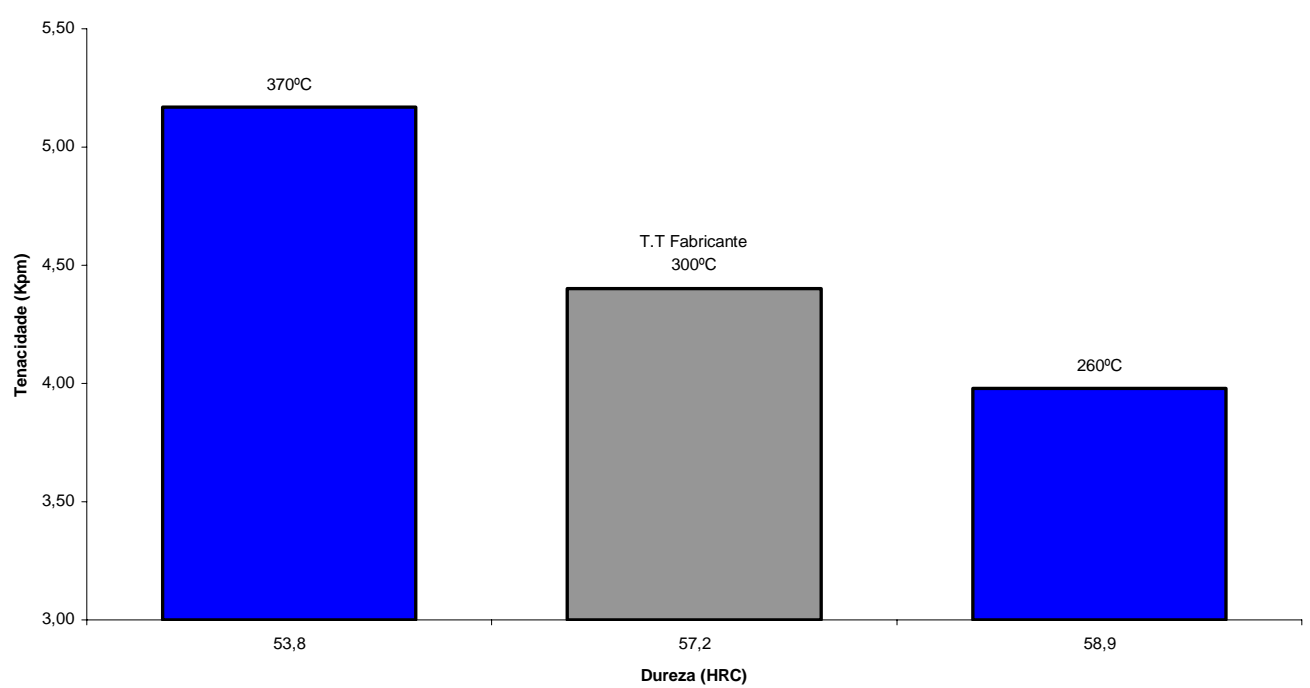

Figura 31: Tenacidade em função da dureza para o aço VND. 
Na figura 32 estão apresentados os módulos de ruptura do aço VND em função da dureza, obtidos no teste de flexão-4 pontos. Observa-se que o módulo de ruptura aumenta com a dureza, apresentando melhor resultado na temperatura de revenimento de $260^{\circ} \mathrm{C}(58,9 \mathrm{HRC})$.

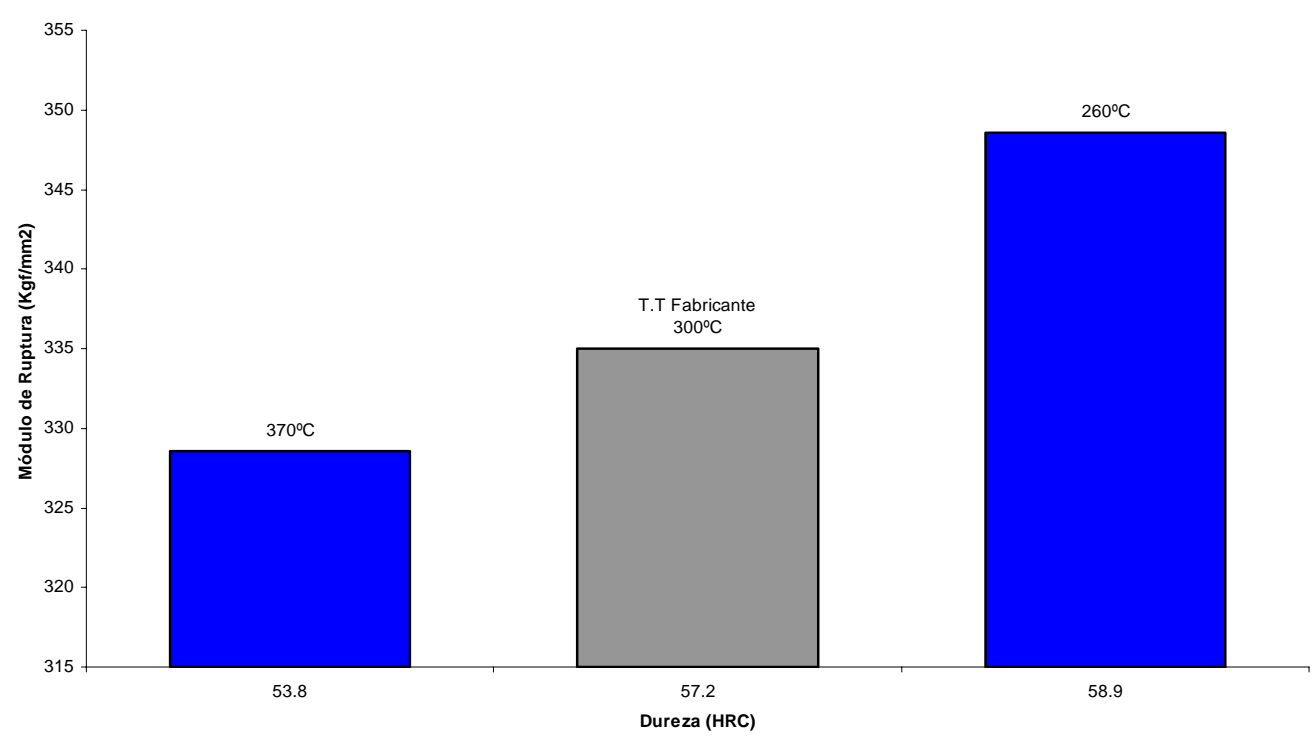

Figura 32: Módulo de ruptura em função da dureza para o aço VND.

As superfícies de relevo de fratura são mostradas nas figuras 33 e 34, observadas em imagem de elétrons secundários (MEV). As figuras mostram o aspecto macroscópico em MEV das faces de fratura em corpos de prova rompidos em Charpy. [19,47].

O exame das faces de fratura apresentadas na figura 33 abaixo indica um comportamento frágil. Pode-se observar mediante análise da direção de propagação das trincas (setas pretas) um caráter descontínuo de propagação, em virtude do campo de tensões gerado pela flexão aplicada no ensaio. A trinca muda a trajetória, sofrendo inclusive re-nucleação (setas brancas). 

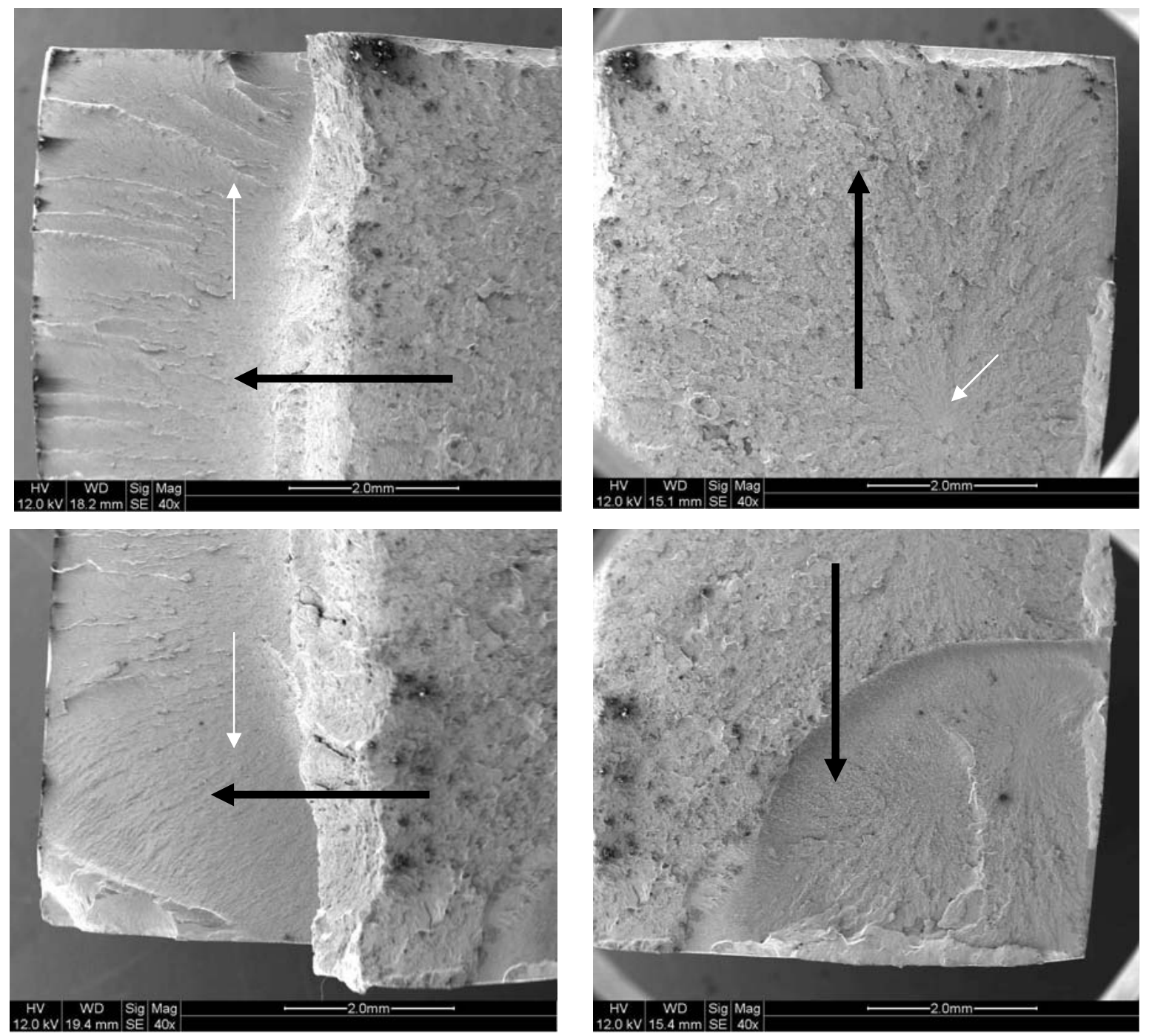

Figura 33: Fractografia típica mostrando a superfície de fratura do corpo-de-prova do aço VND. Seta branca indicando provável região de inicio de fratura.

O exame da figura 34 mostra que o mecanismo de fratura predominante do aço VND é o de quasi clivagem. 


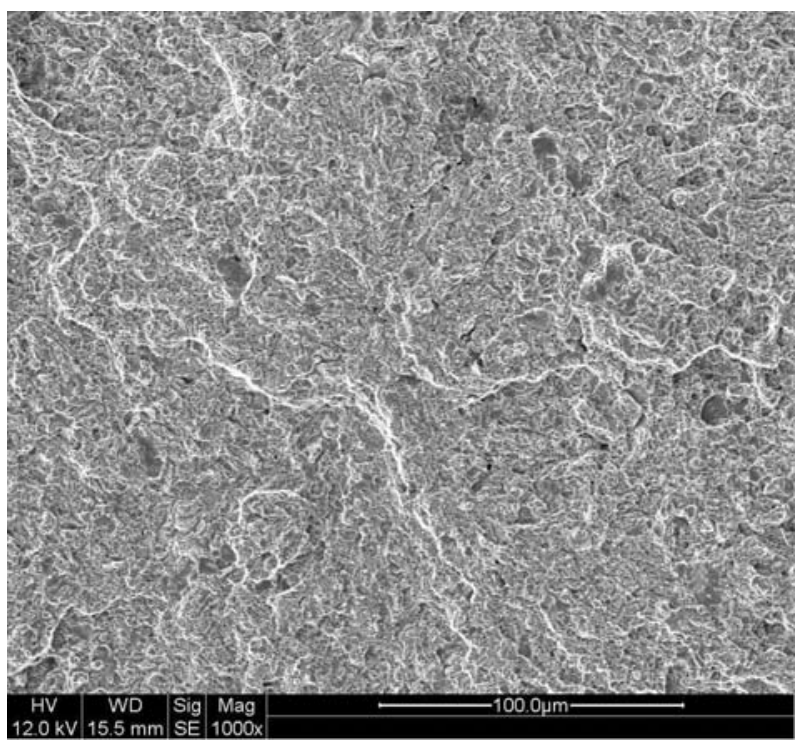

Figura 34: Aumento em região da figura anterior, mostrando a região próxima ao centro.

A recomendação do fabricante para temperatura de revenimento de $300^{\circ} \mathrm{C}(57,2$ HRC) está de acordo com os resultados obtidos neste estudo, pois o aço VND apresentou melhores resultados quando a temperatura de revenimento é de $300^{\circ} \mathrm{C}$.

\subsubsection{Aço Calmax no estado temperado e revenido}

$\mathrm{Na}$ figura 35 estão apresentadas as secções transversais do aço calmax temperado, e temperado e revenido nas temperaturas de 200, 250, 300, 350, 400, 450 e $500^{\circ} \mathrm{C}$.

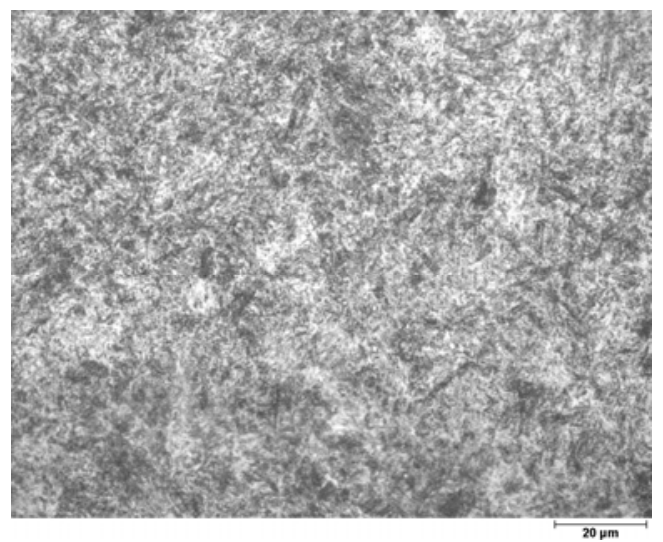

(a)

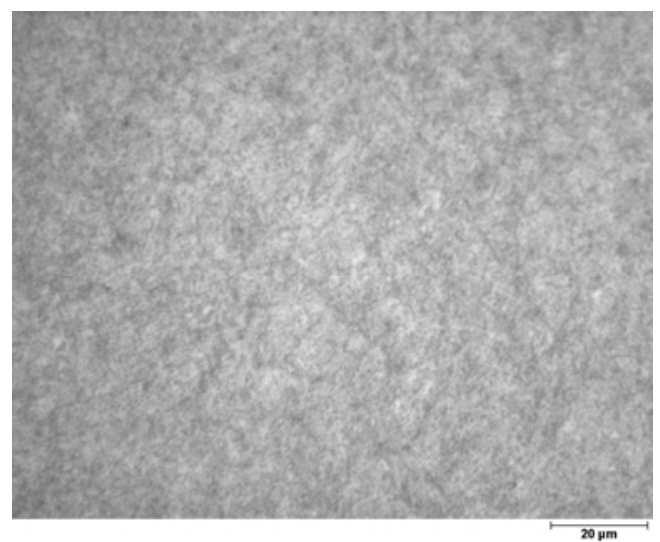

(b) 


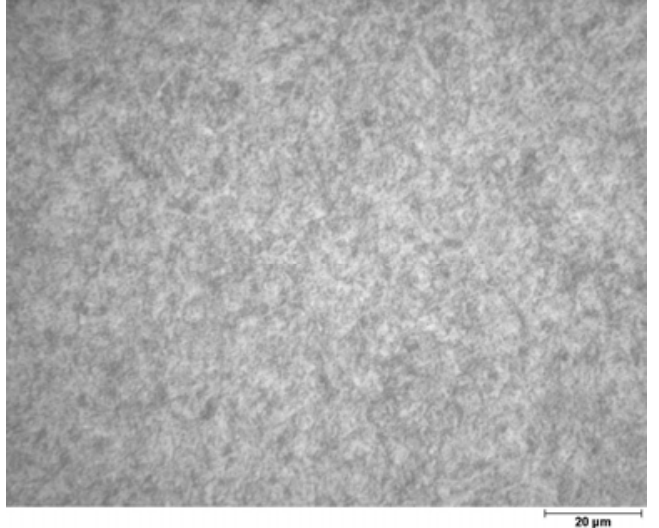

(c)

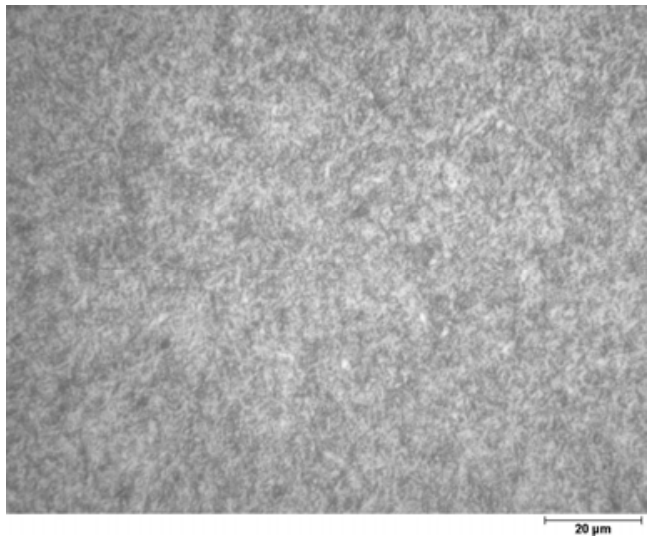

(e)

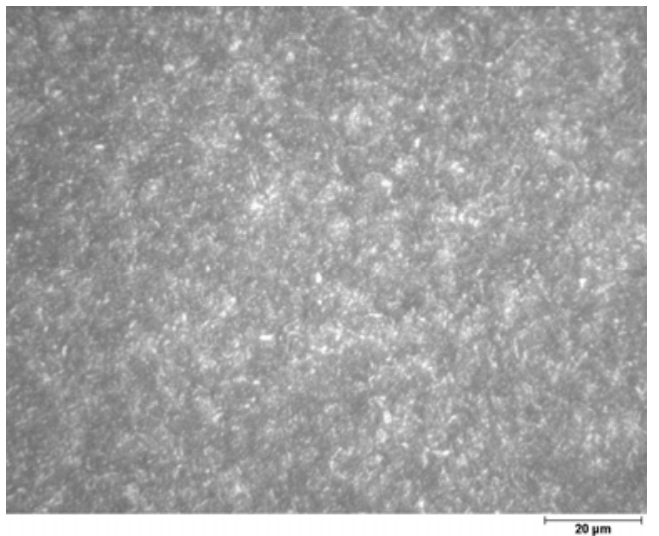

(g)

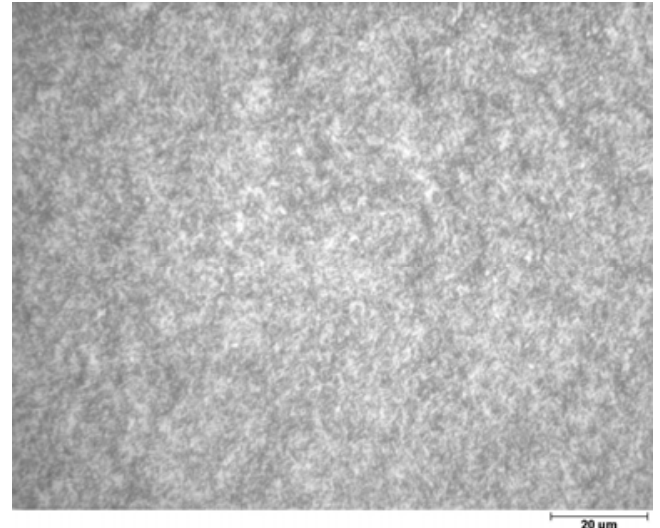

(d)

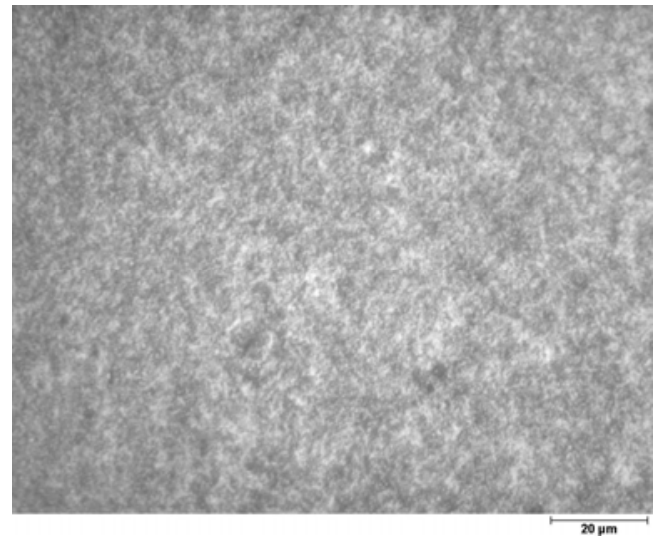

(f)

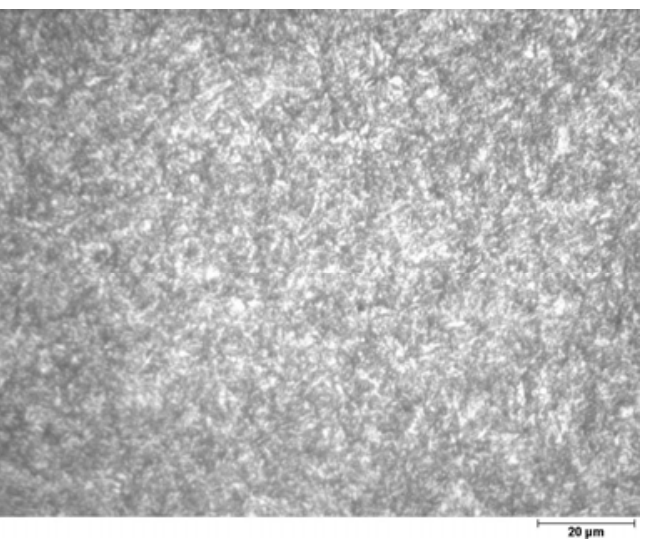

(h

Figura 35: Secções transversais do aço Calmax. (a) somente temperado; (b) temperado e revenido a $200^{\circ} \mathrm{C}$; (c) temperado e revenido a $250^{\circ} \mathrm{C}$; (d) temperado e revenido a $300^{\circ} \mathrm{C}$; (e) temperado e revenido a $350^{\circ} \mathrm{C}$; (f) temperado e revenido a $400^{\circ} \mathrm{C}$; (g) temperado e revenido a $450^{\circ} \mathrm{C}$; (h) temperado e revenido a $500^{\circ} \mathrm{C}$.

$\mathrm{Na}$ figura 36 está apresentada a microestrutura do aço Calmax apenas temperado. Observa-se a matriz martensítica e carbonetos ricos em cromo, provavelmente do tipo $\mathrm{M}_{3} \mathrm{C}$. 


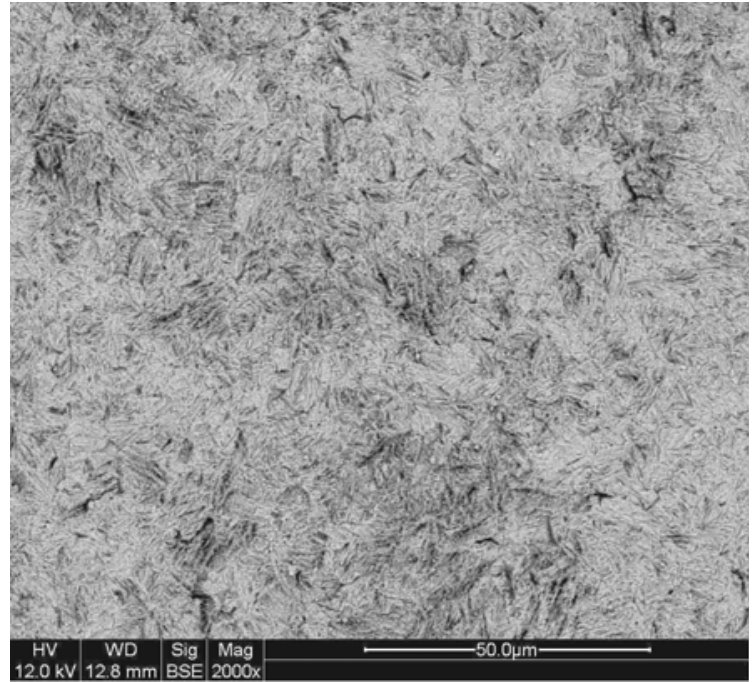

(a)

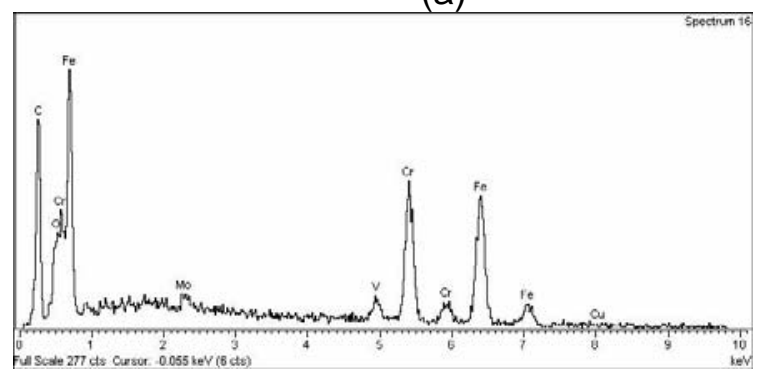

(c)

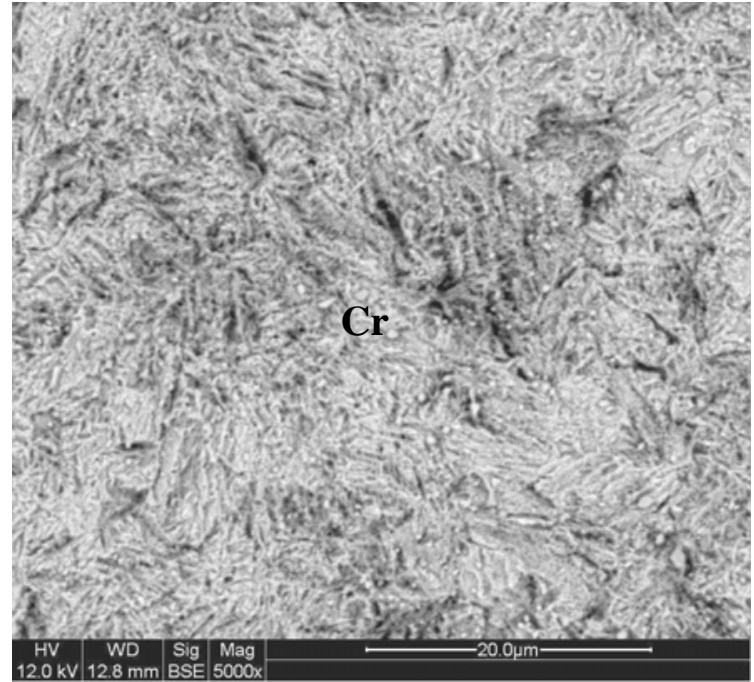

(b)

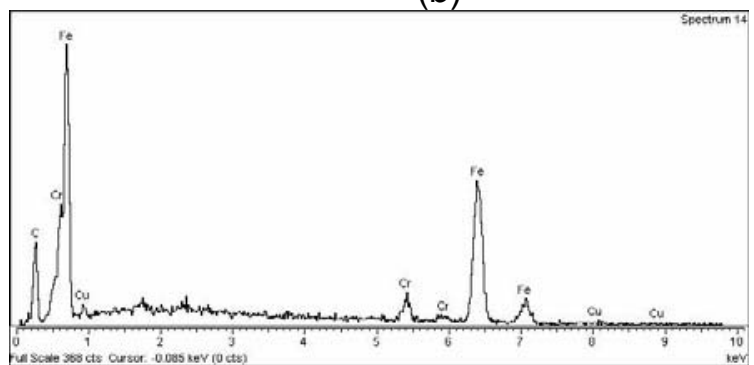

(d)

Figura 36: (a) Seção transversal Calmax somente temperado. Marble; (b) Detalhe seção transversal Calmax somente temperado. Marble; (c) EDS carbonetos ricos em cromo possivelmente do tipo $\mathrm{M}_{3} \mathrm{C}$; (d) EDS da matriz.

A figura 37 é o mesmo aço temperado e revenido. Observa-se martensita revenida como fase predominante. Análise via EDS indicam a presença de carbonetos ricos em cromo.

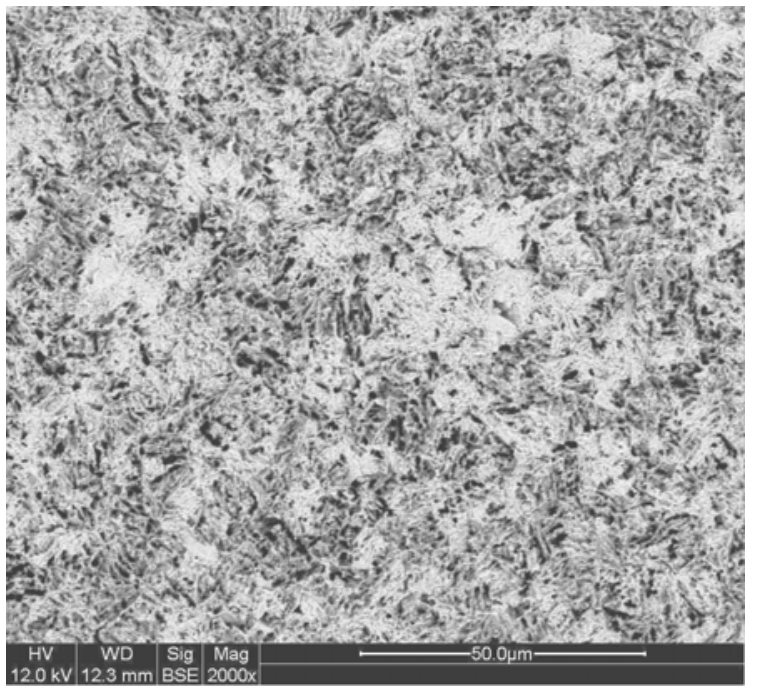

(a)

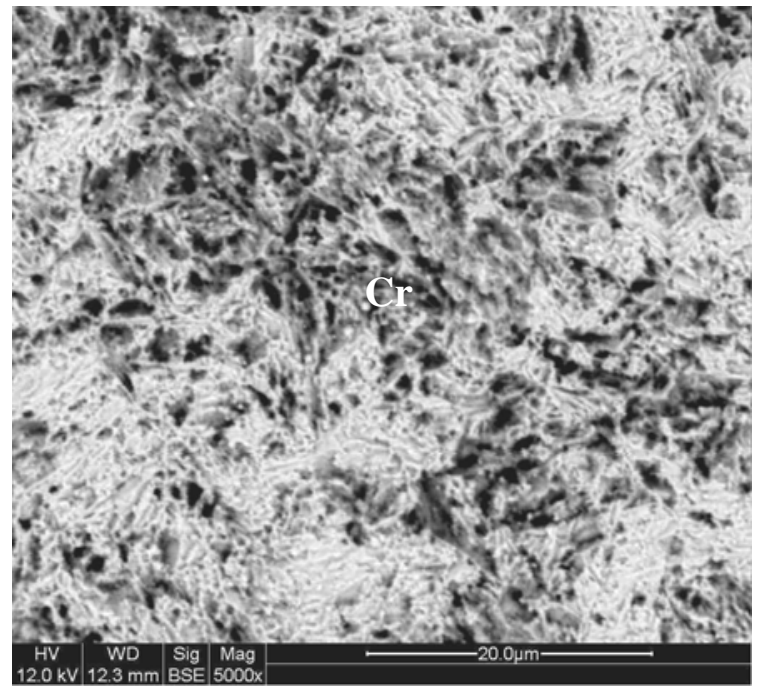

(b) 


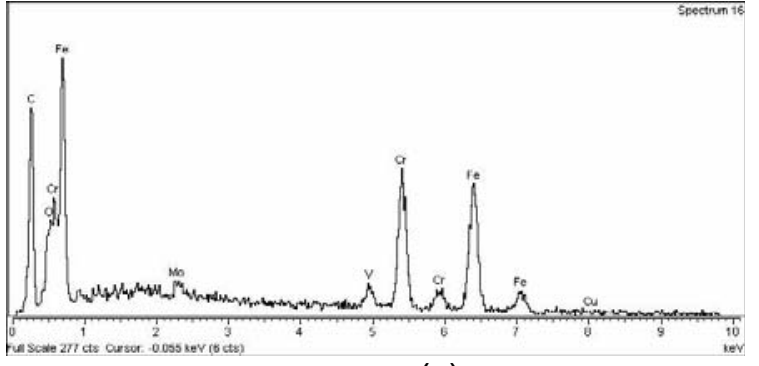

(c)

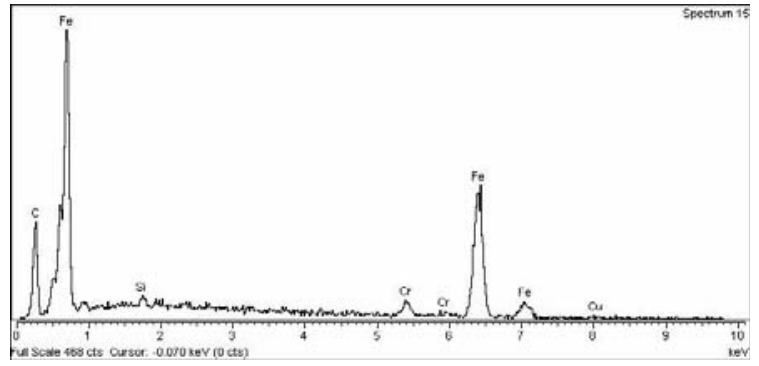

(d)

Figura 37: (a) Secção transversal do aço Calmax temperado e revenido a $300^{\circ} \mathrm{C}$. Ataque Nital 3\%; (b) aumento em região da figura (a); (c) EDS dos carbonetos; (d) EDS da matriz.

Na figura 38 está apresentado o gráfico de dureza em função da temperatura de revenimento para o aço Calmax.

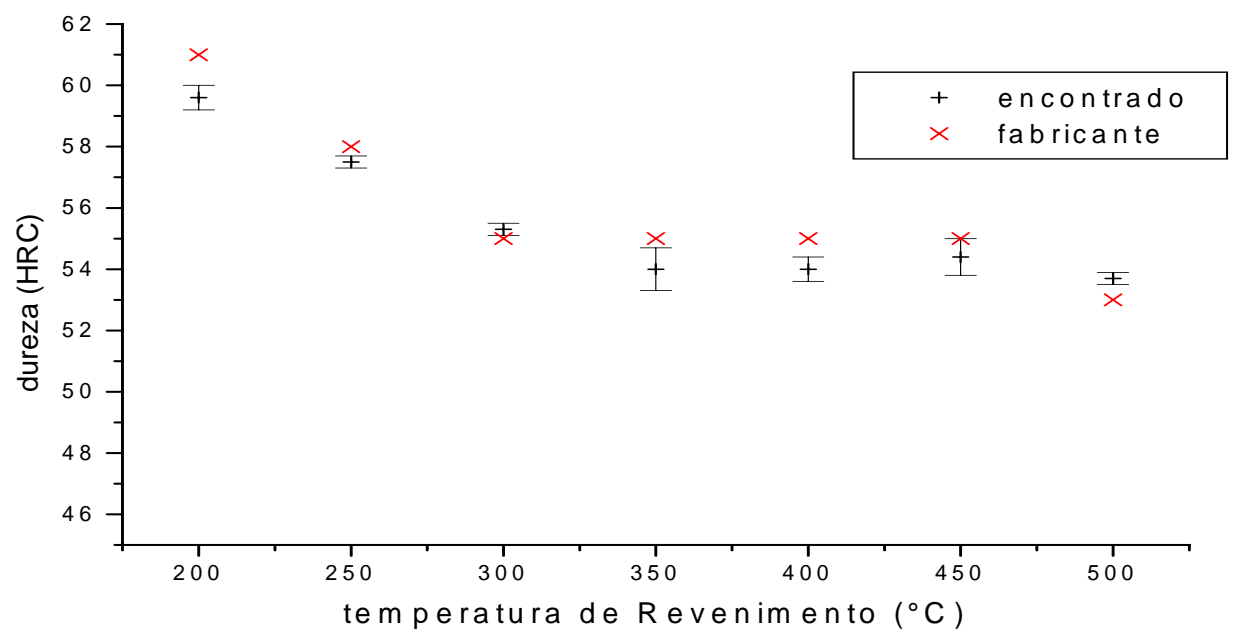

Figura 38: Dureza em função da temperatura de revenimento para o aço Calmax.

A dureza indicada pela curva do fabricante apresenta baixo desvio em relação à curva de dureza obtida nos tratamentos térmicos realizados. O pico de dureza foi obtido com revenimento a $200^{\circ} \mathrm{C}(59,6 \mathrm{HRC})$. Observou-se que a dureza decresce com o aumento da temperatura de revenimento. Entre as temperaturas de revenimento $300^{\circ} \mathrm{C} \mathrm{e}$ $450^{\circ} \mathrm{C}$ ( $54 \mathrm{HRC}$ ), não há variação significativa de dureza, conforme indicado na curva do fabricante, porém as propriedades variam apresentando melhores resultados próximo a $300^{\circ} \mathrm{C}$ e piores próximo a $450^{\circ} \mathrm{C}$. O limite de resistência varia com a dureza, apresentando bons índices nas temperaturas de revenimento de $250^{\circ} \mathrm{C}$ (57,5 HRC) e $300^{\circ} \mathrm{C}(55,3 \mathrm{HRC})$. A tenacidade também varia com a dureza, mostrando melhores índices nas temperaturas de $300^{\circ} \mathrm{C}(55,3 \mathrm{HRC})$ e $350^{\circ} \mathrm{C}(54 \mathrm{HRC})$. 


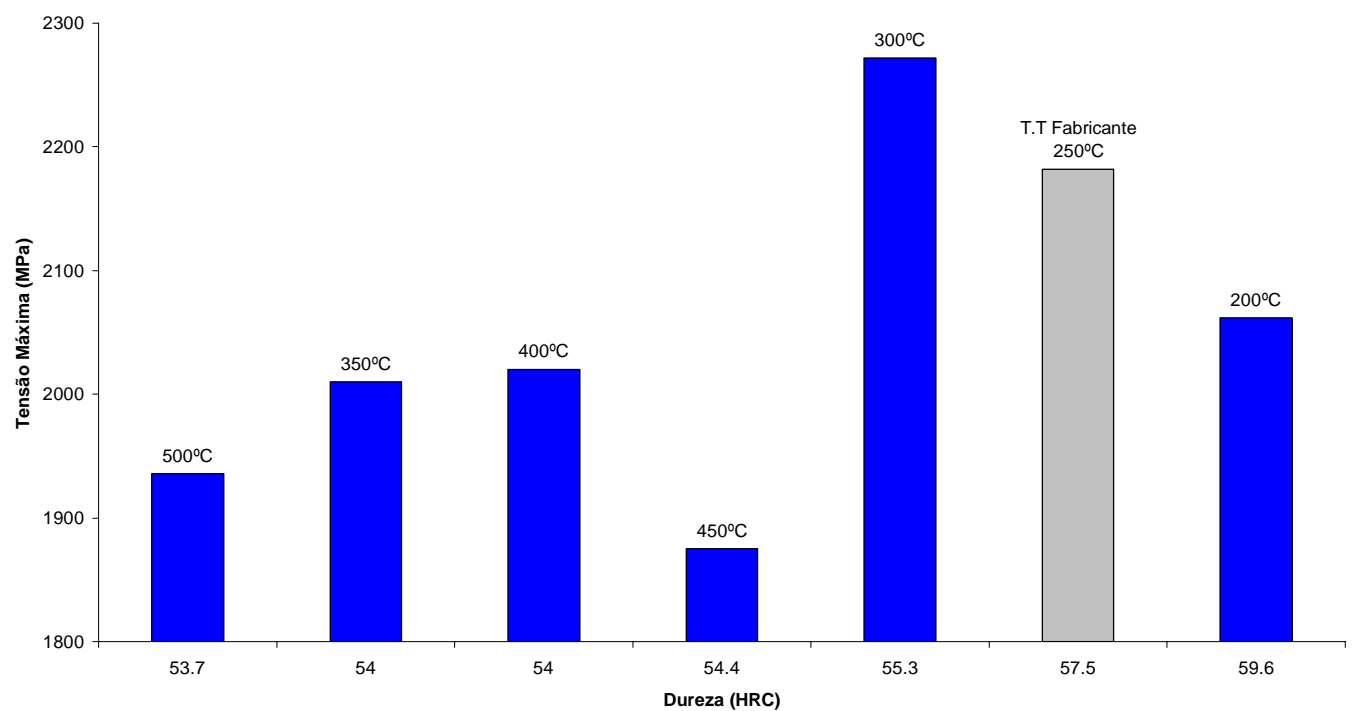

Figura 39: Limite de resistência em função da dureza para o aço Calmax.

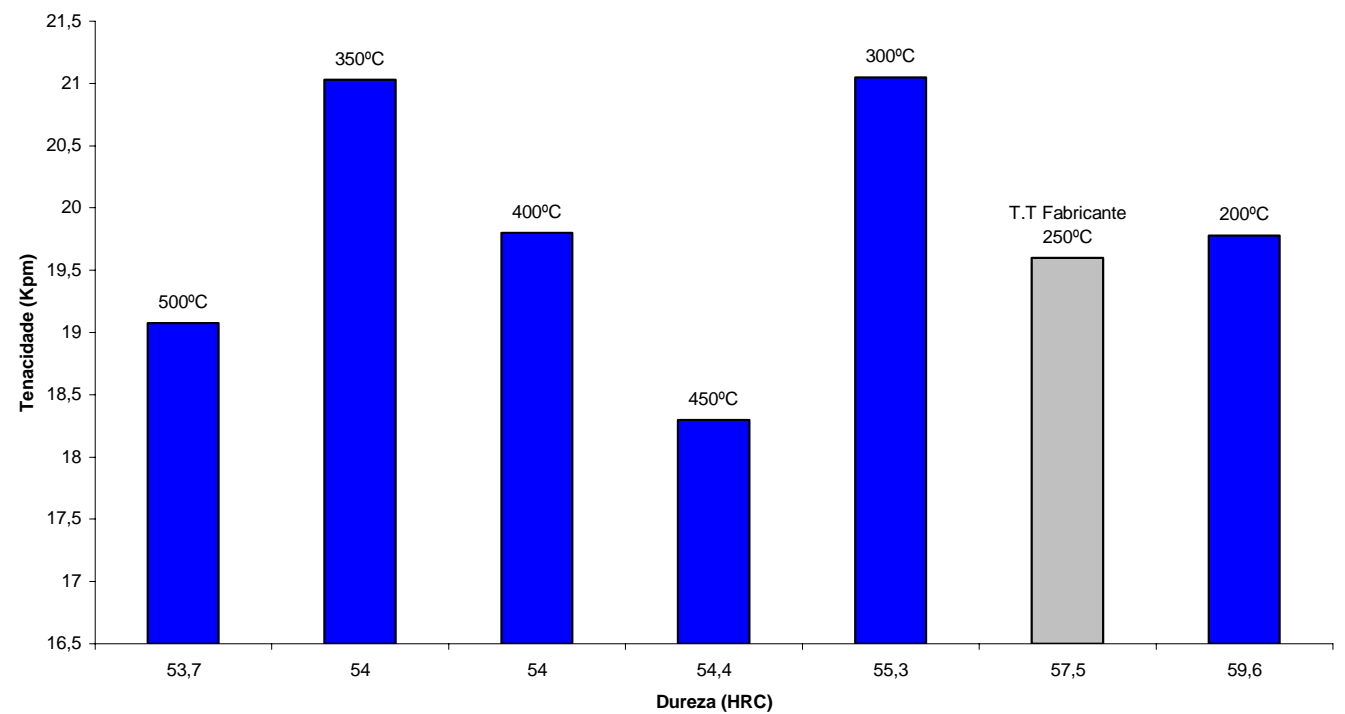

Figura 40: Tenacidade à fratura em função da dureza para o aço Calmax.

A resistência à carga máxima apresenta maior índice na temperatura de revenimento de $250^{\circ} \mathrm{C}(57,5 \mathrm{HRC})$, condizente com a recomendação do fabricante. $\mathrm{Na}$ temperatura de revenimento de $350^{\circ} \mathrm{C}(54 \mathrm{HRC})$ o material também apresenta bom índice nesta propriedade. 


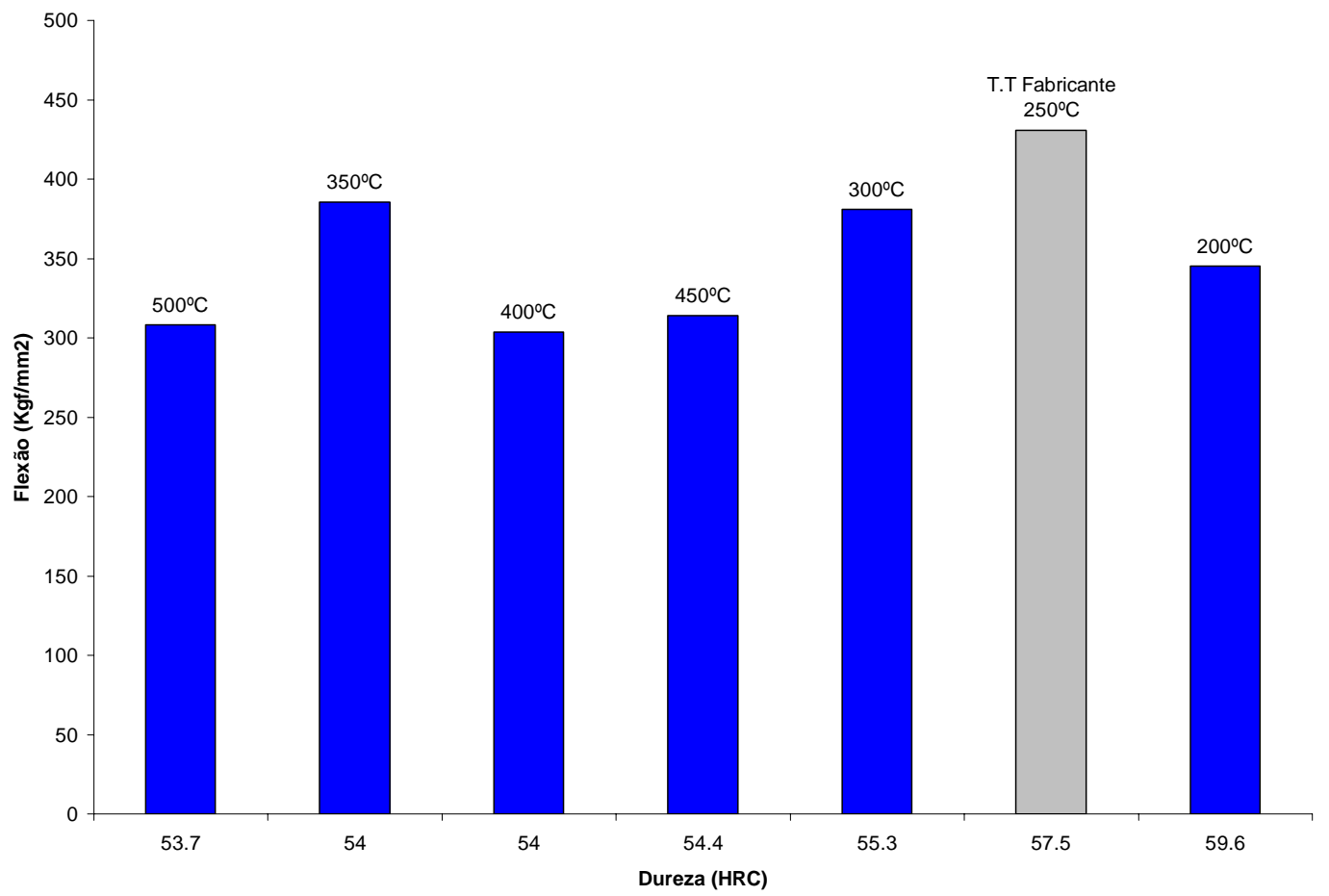

Figura 41: Módulo de ruptura em função da dureza para o aço Calmax.

As superfícies típicas de relevo de fratura são mostradas nas figuras 42 e 43, observadas em imagem de elétrons secundários (MEV). As figuras mostram o aspecto das faces de fratura em corpos de prova rompidos em ensaio Charpy [19].

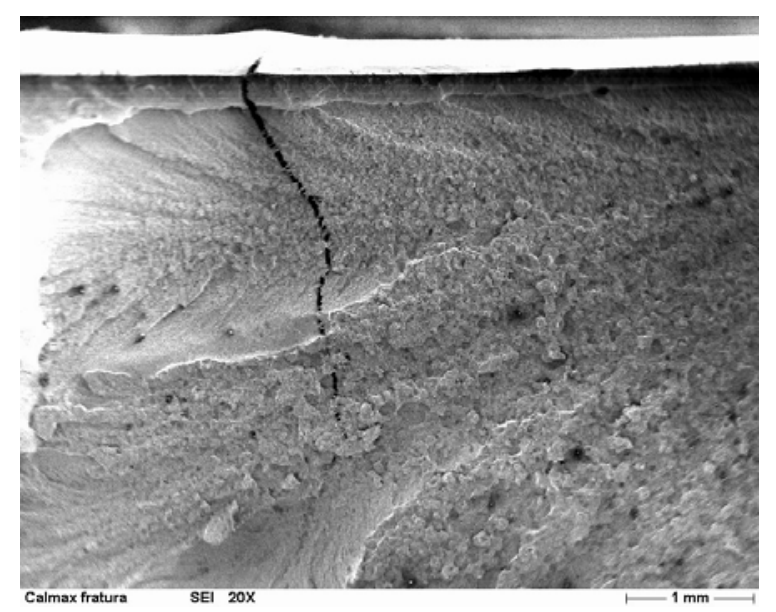

(a)

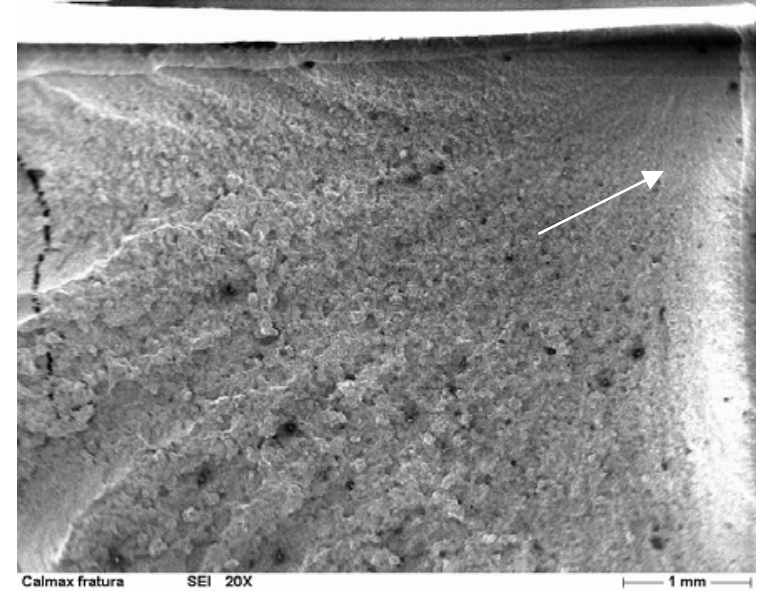

(b) 


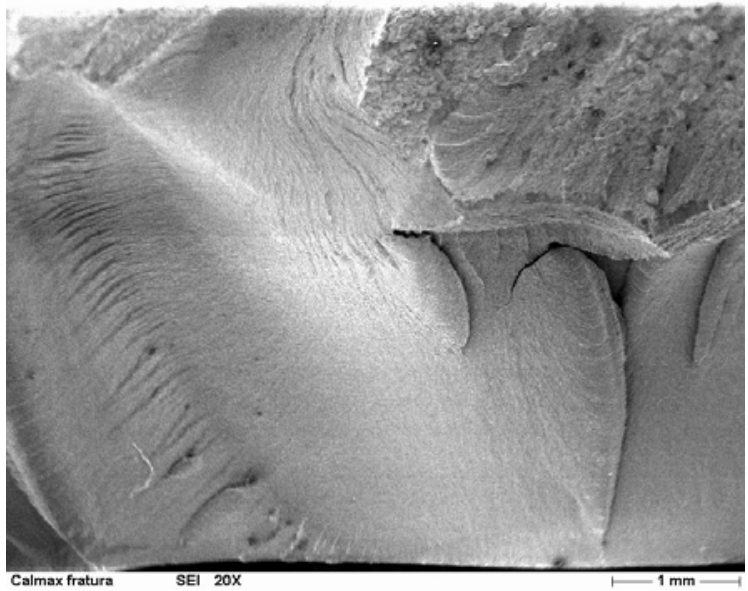

(c)

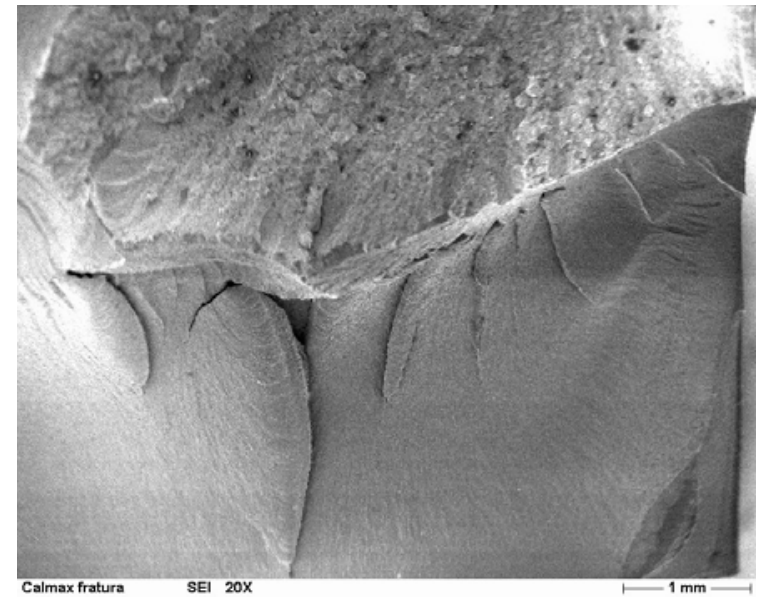

(d)

Figura 42: Fractografia típica mostrando a superfície de fratura do corpo-de-prova do aço Calmax. Seta branca indica região de provável inicio de fratura.

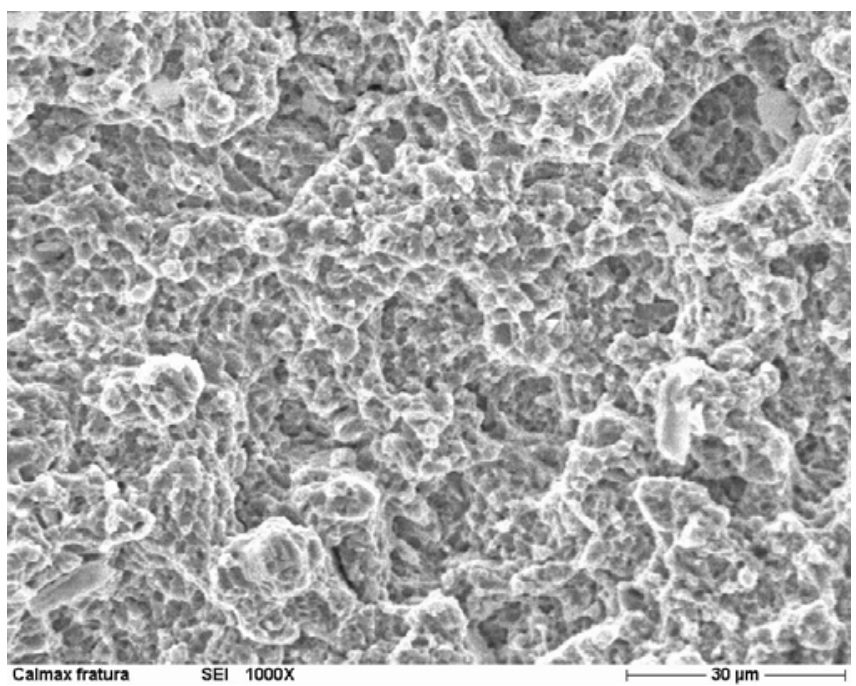

Figura 43: Aumento em região da figura anterior, próxima à borda. Região de provável início da fratura indicado por seta branca.

O exame das faces de fratura apresentadas na figura 42 e 43 indicam comportamento similar ao dos outros aços, porém com particularidade de ocorrência de grande variação na topografia, indicando que a propagação da trinca foi dificultada pela matriz [47].

A recomendação do fabricante para temperatura de revenimento $250^{\circ} \mathrm{C}(57,5$ HRC) não está totalmente de acordo com os resultados obtidos neste estudo, pois para o aço Calmax observou-se que as temperaturas de revenimento de $300^{\circ} \mathrm{C}$ e $350^{\circ} \mathrm{C}$ mostraram bons índices em tenacidade e resistência, apesar de apresentarem menor dureza. 


\subsubsection{Aço VF-800 no estado temperado e revenido}

$\mathrm{Na}$ figura 44a está apresentada a micrografia da secção transversal do aço VF800. Nas figuras $44 \mathrm{~b}-\mathrm{f}$ estão apresentadas às secções transversais do mesmo aço temperado e revenido nas temperaturas de $300,475,540,550$ e $580^{\circ} \mathrm{C}$, respectivamente. As micrografias foram obtidas por microscopia óptica.

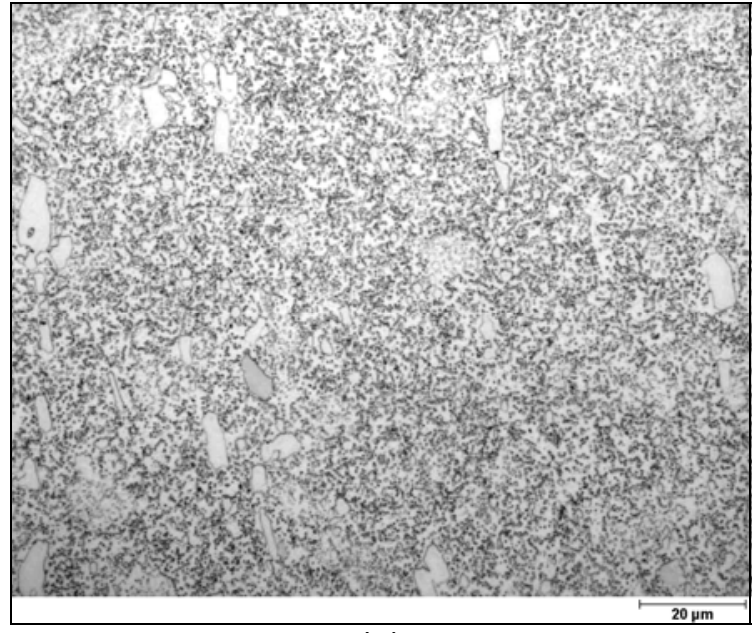

(a)

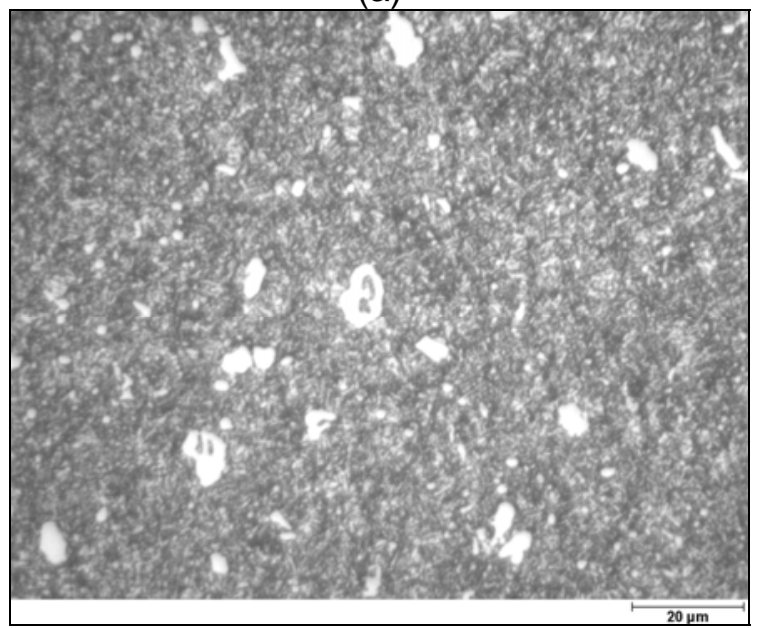

(c)

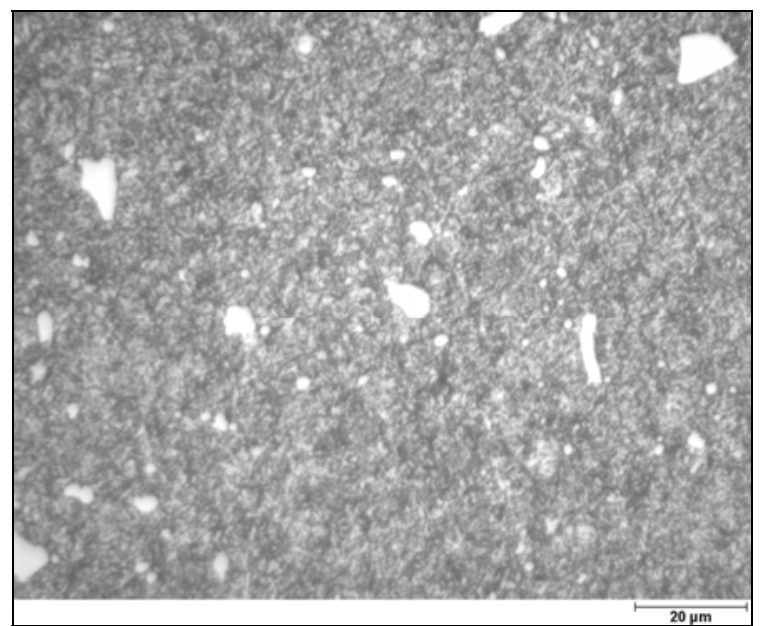

(b)

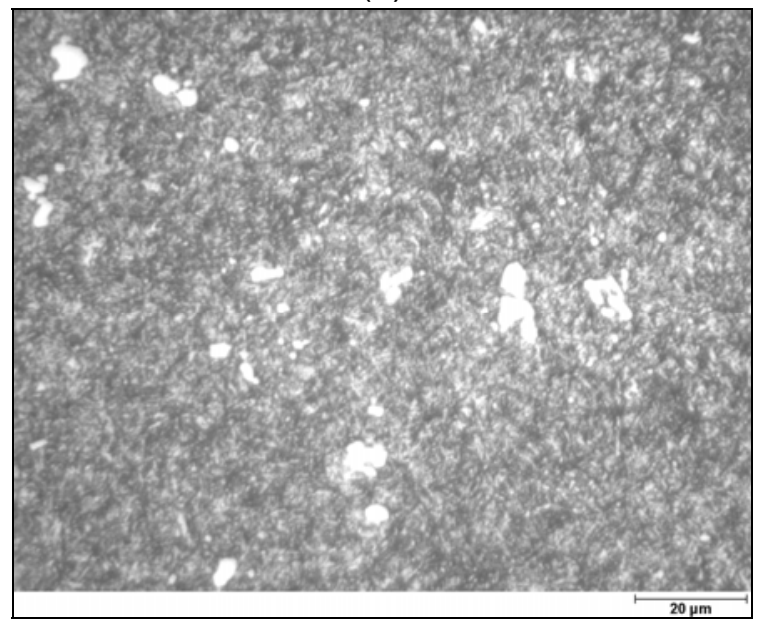

(d) 


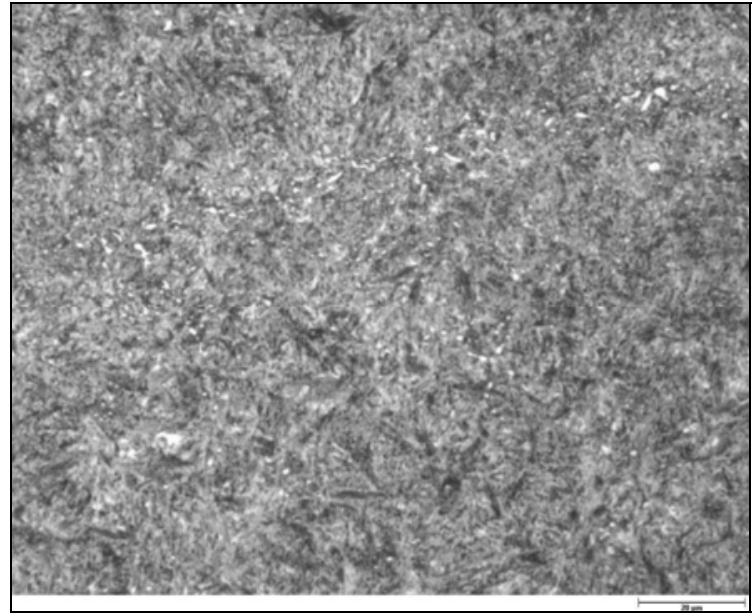

(e)

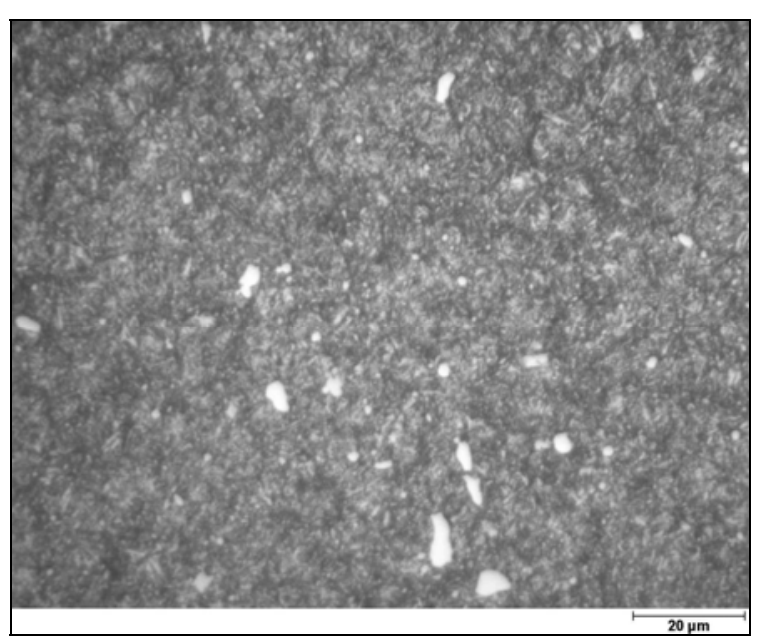

(f)

Figura 44: Secções transversais do aço VF-800. (a) somente temperado; (b) temperado e revenido em $300^{\circ} \mathrm{C}$; (c) temperado e revenido em $475^{\circ} \mathrm{C}$; (d) temperado e revenido em $540^{\circ} \mathrm{C}$; (e) temperado e revenido em $550^{\circ} \mathrm{C}$; (f) temperado e revenido em $580^{\circ} \mathrm{C}$.

$\mathrm{Na}$ figura $45 \mathrm{a}$ está apresentada a microestrutura do aço VF-800 no estado temperado. Observa-se a matriz martensítica e carbonetos ricos em cromo, provavelmente do tipo $\mathrm{M}_{7} \mathrm{C}_{3}$ e ricos em molibdênio, provavelmente do tipo $\mathrm{M}_{2} \mathrm{C}$. Observase a matriz de martensita revenida e precipitados ricos em $\mathrm{Cr}$ (escuros) e Mo (claros). No caso específico de aços-ferramenta de alto carbono, como este, a seqüência de formação de carbonetos ricos em cromo durante o revenimento é dada por $M_{3} C, M_{7} C_{3} e$ $M_{23} C_{6}$ [5,24], e para carbonetos ricos em molibdênio a sequencia é $M_{3} C, M_{2} C, M_{6} C$ $[12,23]$. Nas figuras $45 \mathrm{~b}-\mathrm{c}$, pode-se visualizar a composição aproximada dos carbonetos em uma matriz martensitica através de análise pontual por EDS. Estes carbonetos se constituem em fases primárias (ocorrem por ocasião da solidificação), e indicam carbonetos ricos no elemento cromo (Fig. 45b) e molibdênio (Fig. 45c). A Fig. 45d corresponde à análise da matriz ferrosa, apresentando os elementos típicos constituintes da matriz, indicando o cromo ainda em considerável quantidade na matriz deste açoferramenta após têmpera. 


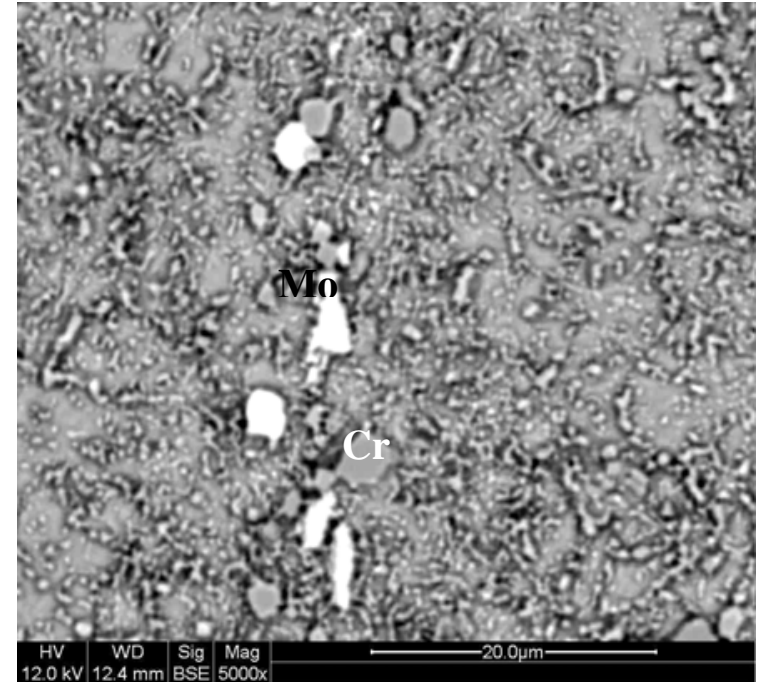

(a)

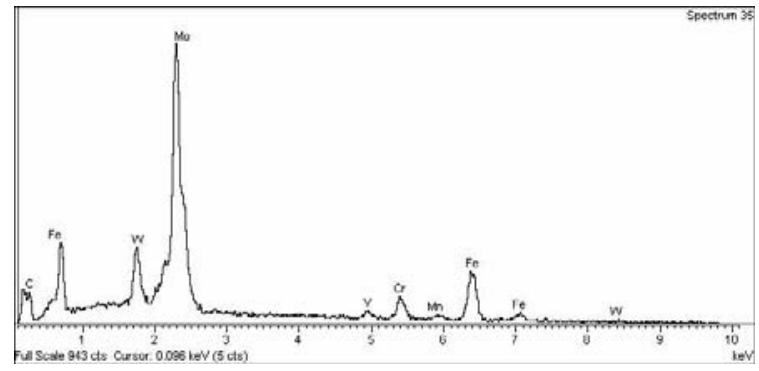

(c)

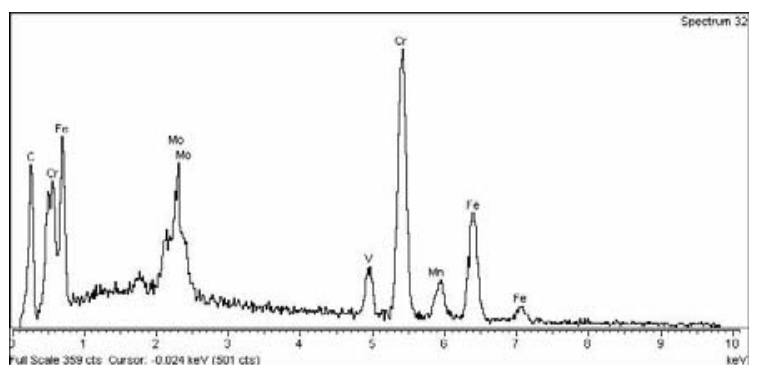

(b)

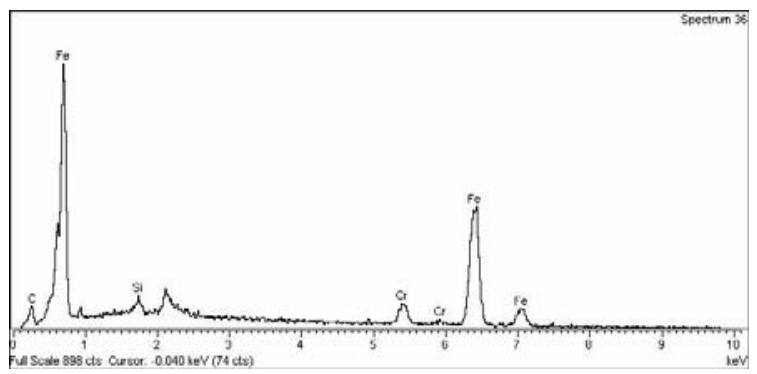

(d)

Figura 45: (a) Secção transversal do aço VF800 somente temperado. Ataque Marble; (b) EDS carbonetos ricos em cromo, possivelmente do tipo $\mathrm{M}_{7} \mathrm{C}_{3}$; (c) EDS carbonetos ricos em molibdênio, possivelmente do tipo $\mathrm{M}_{2} \mathrm{C}$; (d) EDS da matriz.

A figura 46 mostra a microestrutura do aço VF-800 temperado e revenido. Análises de superfície - figuras 46a-b (Imagem de elétrons retroespalhados) mostram martensita revenida como microestrutura predominante. Observam-se carbonetos ricos em Cr e em Mo. 


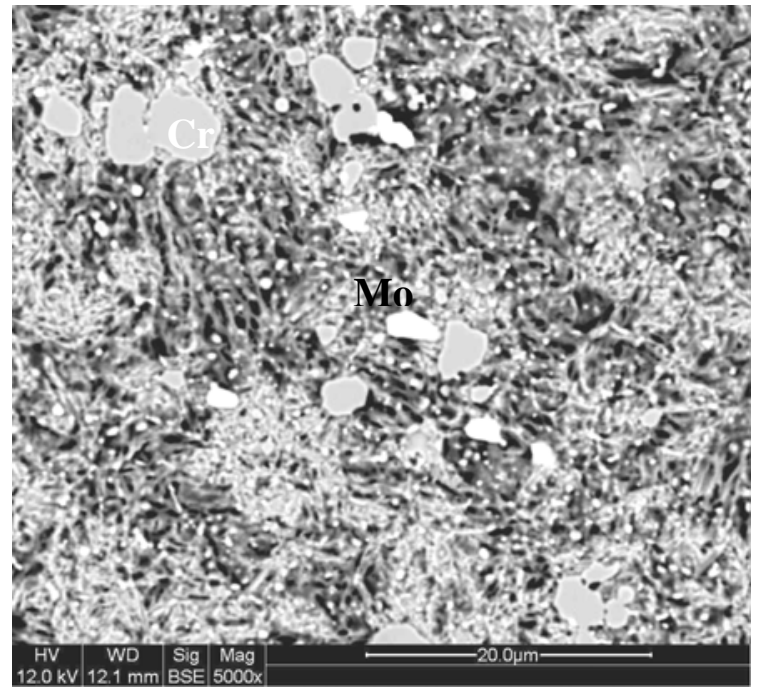

(a)

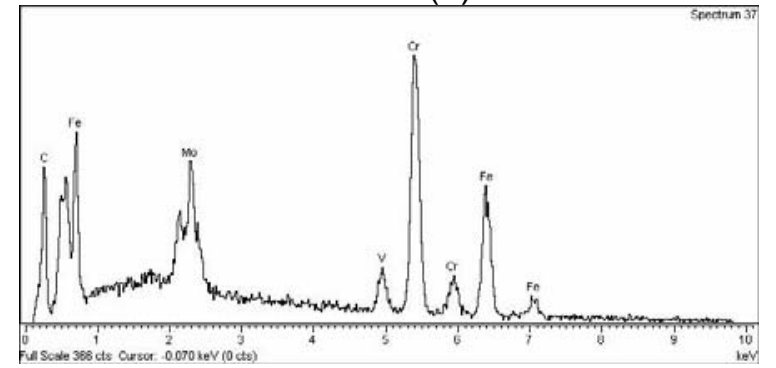

(c)

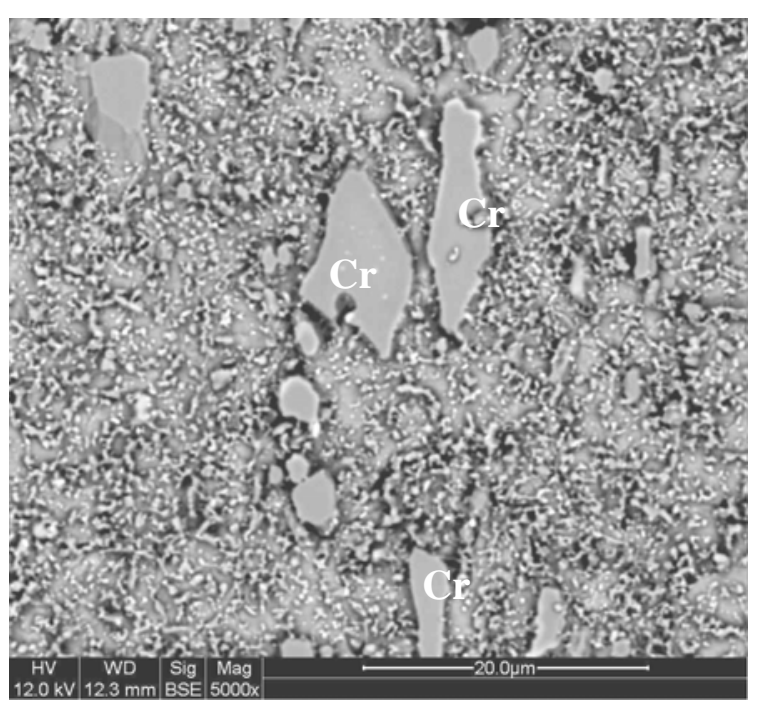

(b)

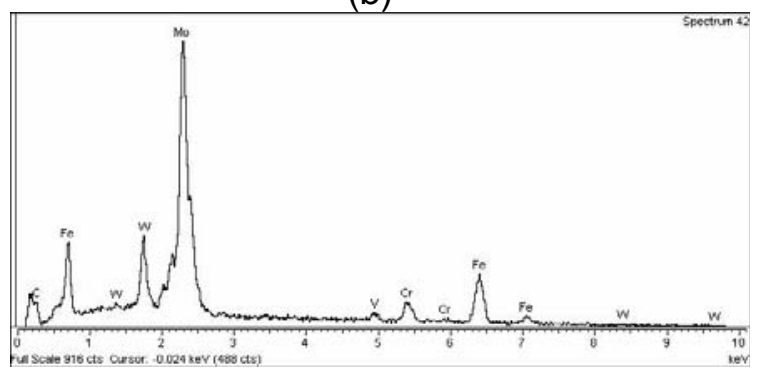

(d)

Figura 46: (a) Secção transversal do VF800 temperado e revenido a $475^{\circ} \mathrm{C}$ - Ataque Marble; (b) Detalhe de carbonetos ricos em cromo (c) EDS carbonetos ricos em cromo possivelmente do tipo $\mathrm{M}_{7} \mathrm{C}_{3}$; (d) EDS dos carbonetos ricos em molibdênio, possivelmente do tipo $\mathrm{M}_{2} \mathrm{C}$.

Observa-se na figura 47 que a dureza indicada pela curva de dureza do fabricante apresenta baixo desvio em relação à curva de dureza obtida nos tratamentos térmicos realizados, exceção feita para a temperatura de revenimento de $300^{\circ} \mathrm{C}(59 \sim 61,7 \mathrm{HRC})$. A dureza decresce com o aumento da temperatura de revenimento, porém apresenta pico de endurecimento em aproximadamente $540^{\circ} \mathrm{C}(61,5 \mathrm{HRC})$, devido ao efeito de dureza secundária, ou seja, precipitação de carbonetos complexos. 


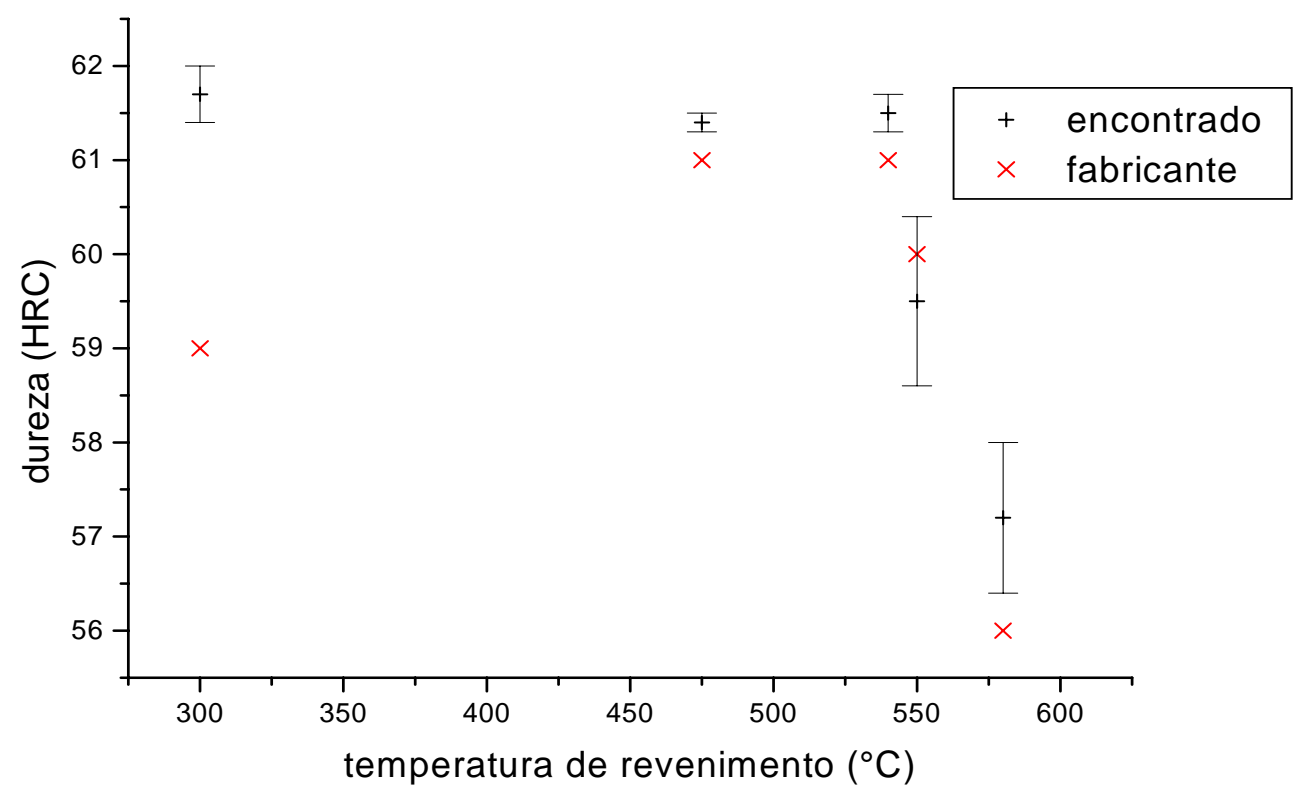

Figura 47: Dureza em função da temperatura de revenimento para o aço VF-800.

Observa-se na figura 48 que o maior limite de resistência ocorre para revenimentos realizados a $475^{\circ} \mathrm{C}(\mathrm{HRC} 61,4)$.

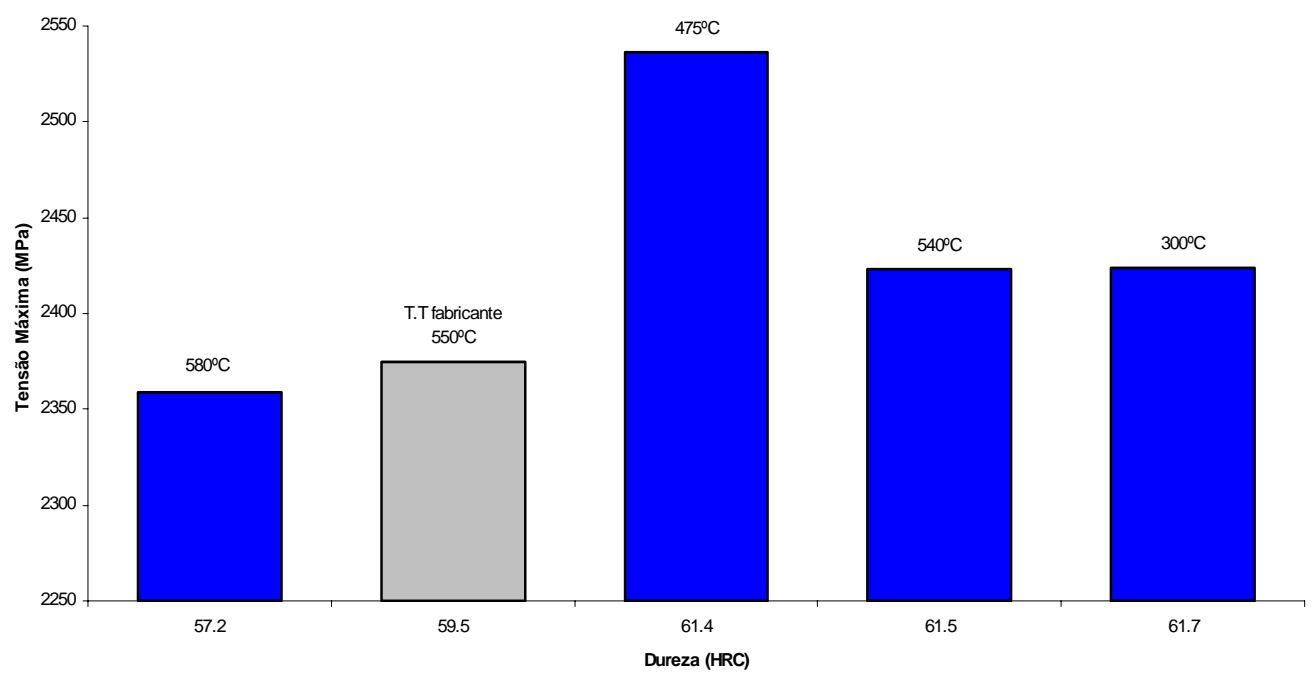

Figura 48: Limite de resistência em função da dureza para o aço VF-800.

$\mathrm{Na}$ figura 49 estão apresentados os resultados obtidos no ensaio charpy. Observa-se que a tenacidade varia em relação à dureza, apresentando bons índices para três das cinco temperaturas de revenimento: $300^{\circ} \mathrm{C}(61,7 \mathrm{HRC}), 475^{\circ} \mathrm{C}(61,4 \mathrm{HRC}) \mathrm{e}$ $580^{\circ} \mathrm{C}(57,2 \mathrm{HRC})$. 


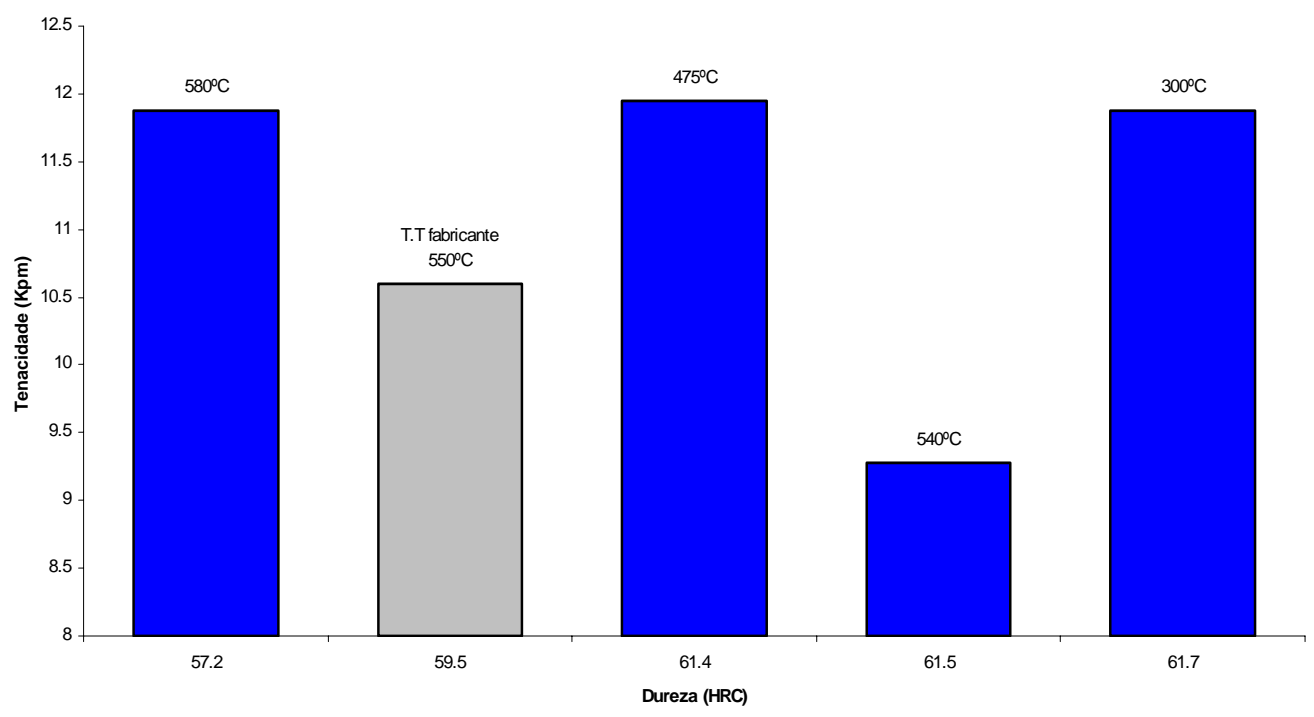

Figura 49: Tenacidade à fratura em função da dureza para o aço VF-800.

A figura 50 mostra os resultados obtidos no teste de flexão-4 pontos para o aço VF-800. Observa-se que a resistência à carga máxima de flexão (módulo de ruptura) varia em relação à dureza, apresentando bons índices em $550^{\circ} \mathrm{C}(59,5 \mathrm{HRC})$ e $475^{\circ} \mathrm{C}$ (61,4 HRC).

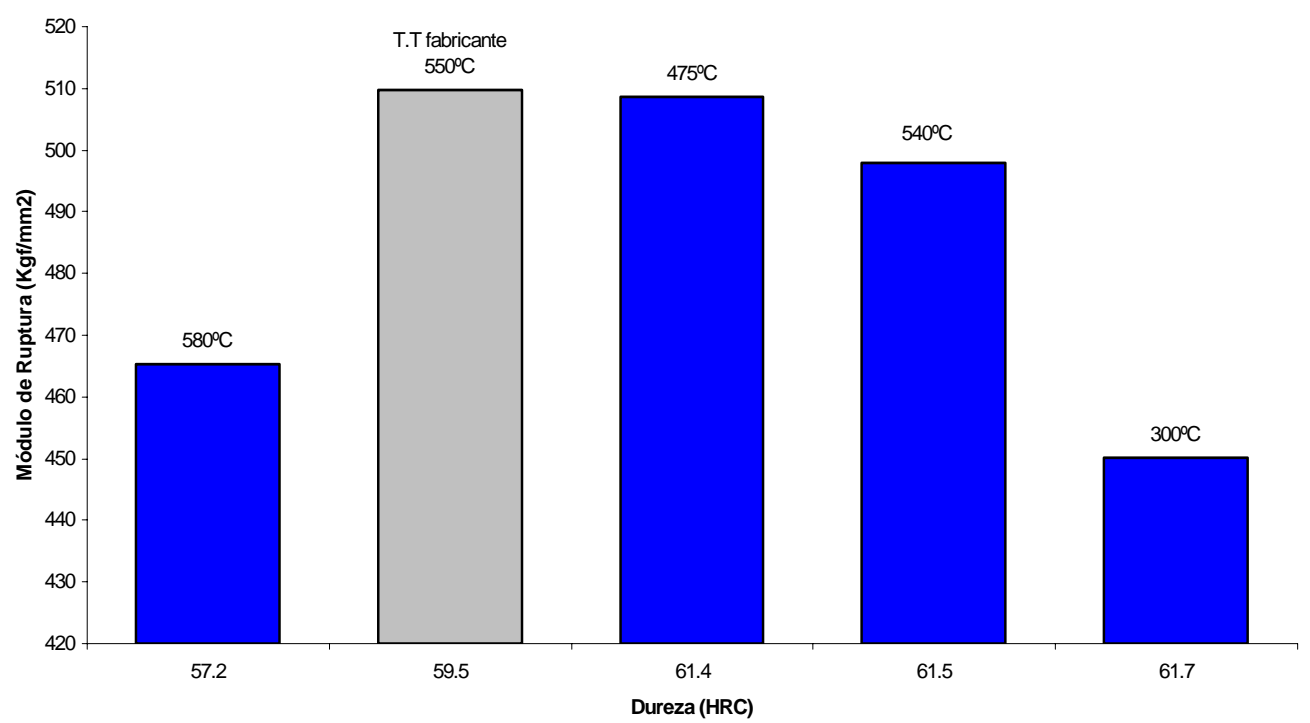

Figura 50: Módulo de ruptura em função da dureza para o aço VF-800. 
As superfícies típicas de relevo de fratura são mostradas nas figuras 51 e 52, vistas em imagem de elétrons secundários (MEV). As figuras mostram o aspecto das faces de fratura em corpos de prova rompidos em testes Charpy $[19,47]$.

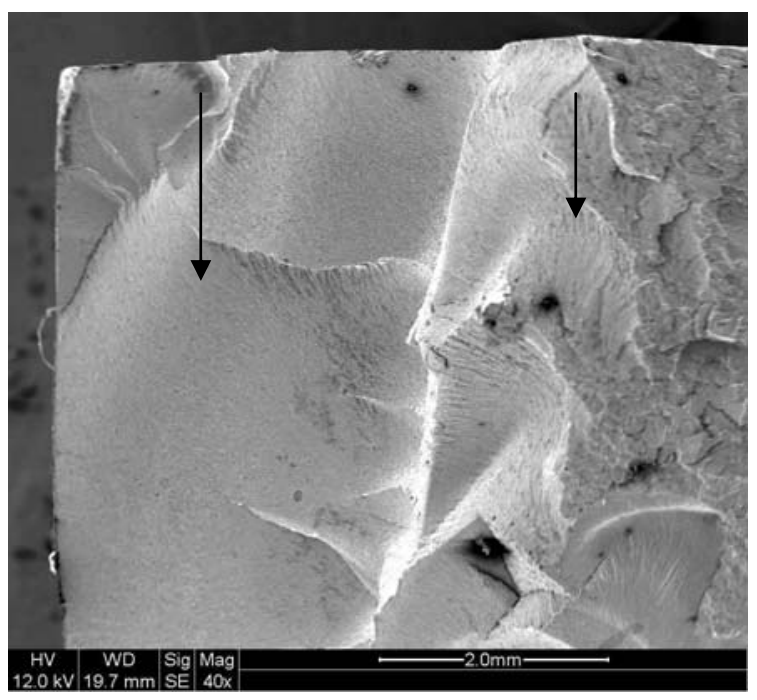

(a)

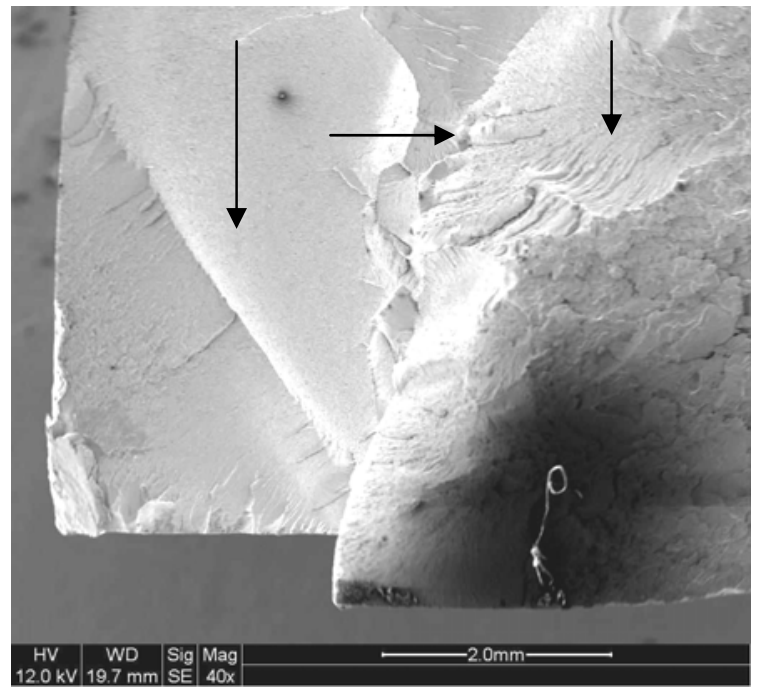

(c)

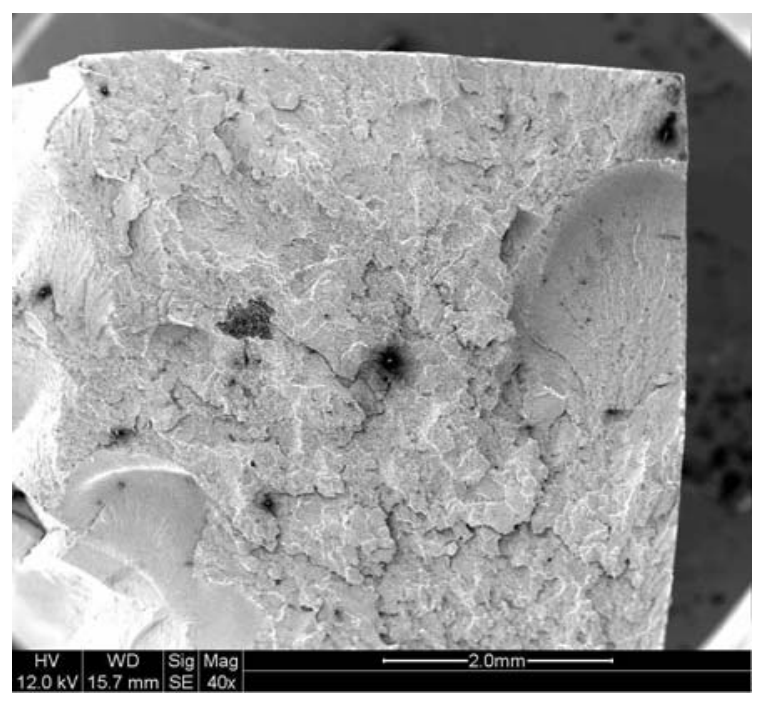

(b)

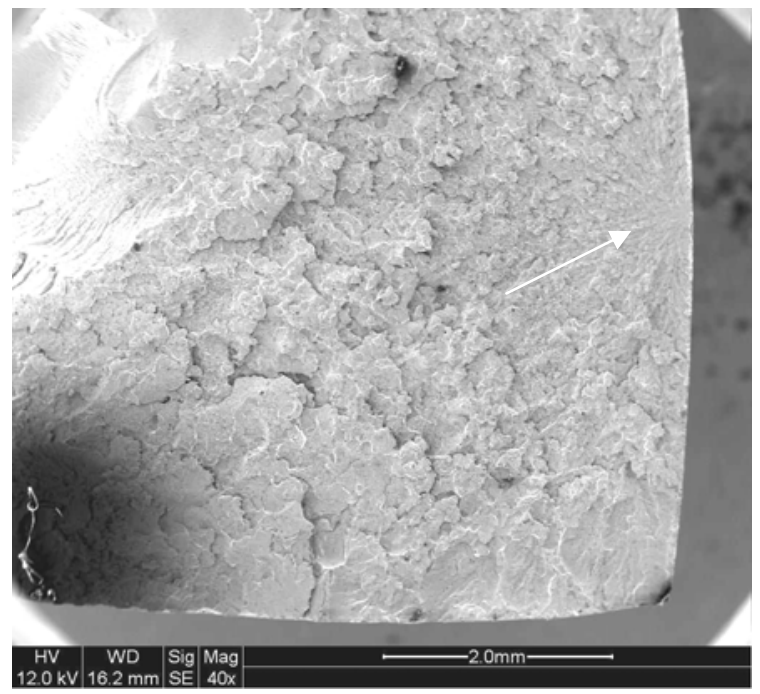

(d)

Figura 51: VF-800: Fractografia típica mostrando a superfície de fratura do corpo-deprova. Seta branca indicando provável região de inicio de fratura.

É possível observar mecanismo de fratura de quasi-clivagem, típico para matriz ferrosa na condição de temperada e revenida, em fratura correspondente à trinca já nucleada. A superfície de fratura da liga VF 800 apresenta caráter frágil do mesmo modo que o VND, indicando, no entanto, uma propagação mais descontínua, com um maior número de re-nucleações, conforme indicam as setas pretas $[46,47]$. O exame da figura 52 mostra que o mecanismo de fratura predominante da liga VF-800 é o de quasi clivagem. 


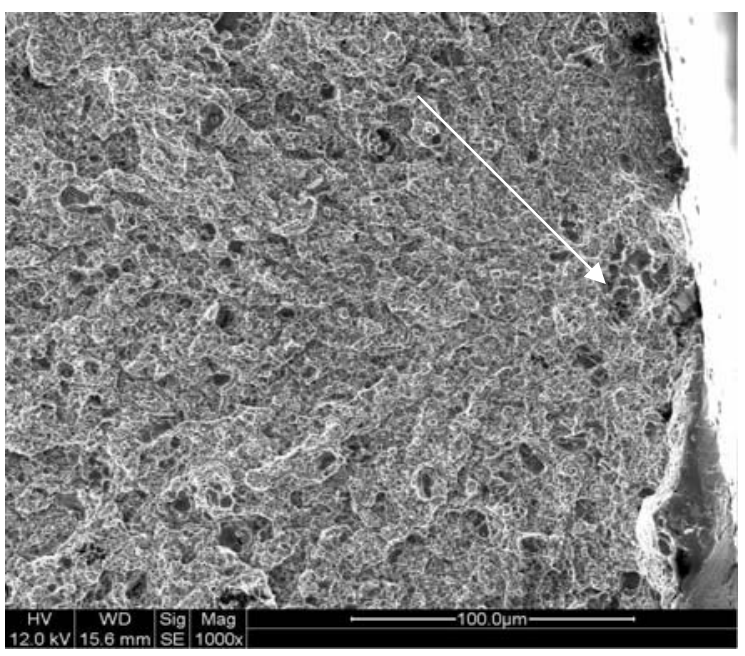

Figura 52: VF-800: Detalhe da figura anterior, mostrando a região próxima à borda. Região de provável início da fratura.

A recomendação do fabricante para temperatura de revenimento de aproximadamente $550^{\circ} \mathrm{C}$ (59,5 HRC) não está completamente de acordo com os resultados obtidos neste estudo, pois o aço VF-800 apresentou melhor desempenho quando revenido na temperatura de revenimento de $475^{\circ} \mathrm{C}$;

\subsubsection{Aço Vanadis 10 no estado temperado e revenido}

$\mathrm{Na}$ figura 53a está apresentada a micrografia óptica do aço Vanadis 10 temperado. As figuras 53b-d são do mesmo aço temperado e revenido nas temperaturas de 430,525 e $550^{\circ} \mathrm{C}$.

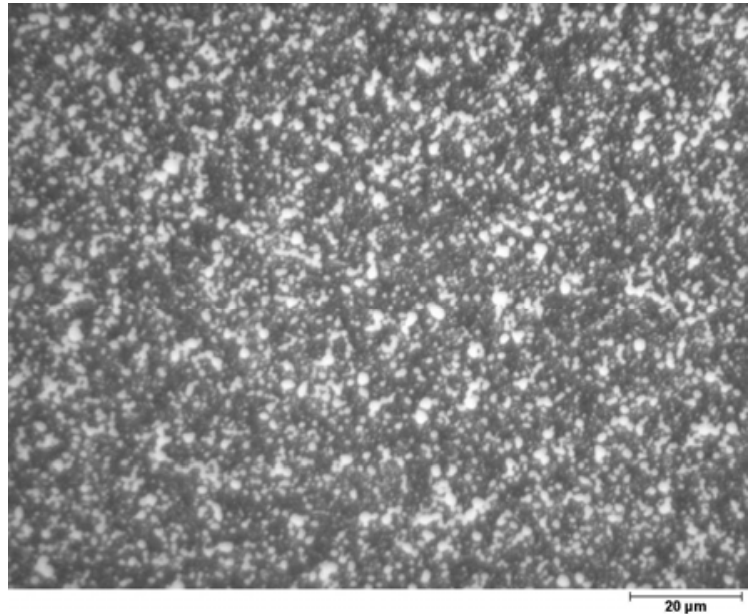

(a)

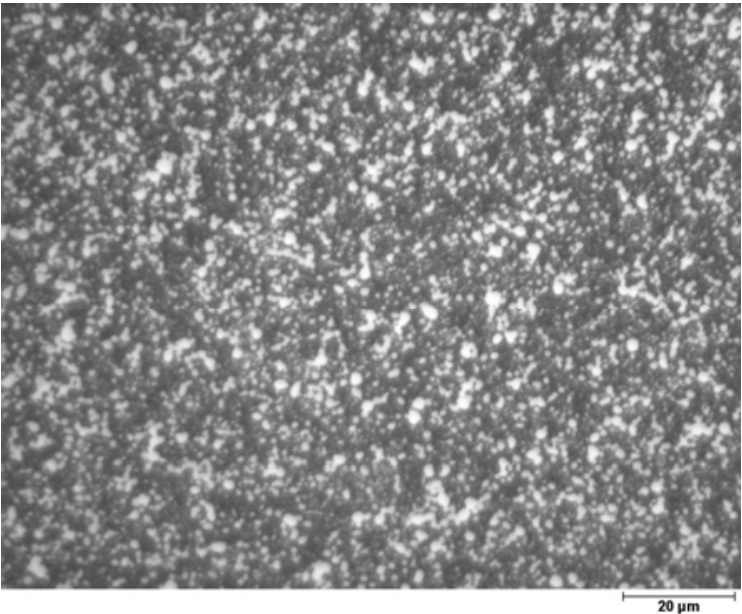

(b) 


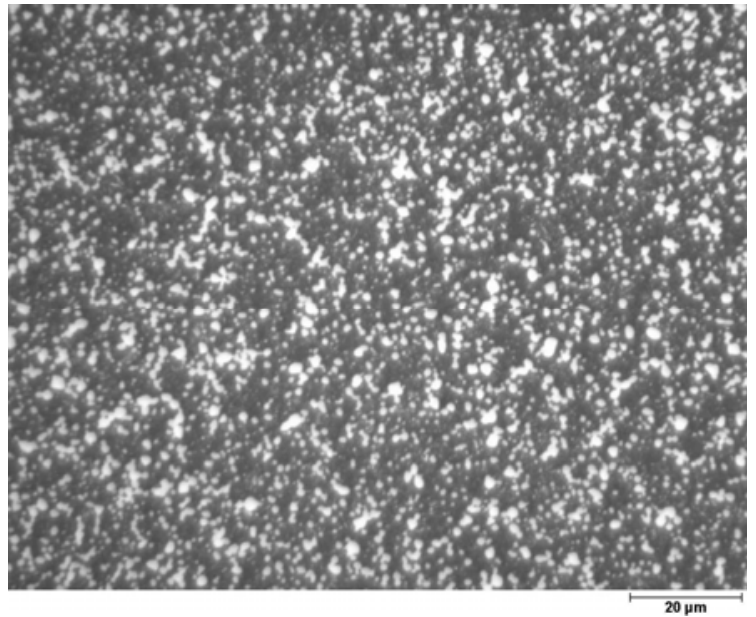

(c)

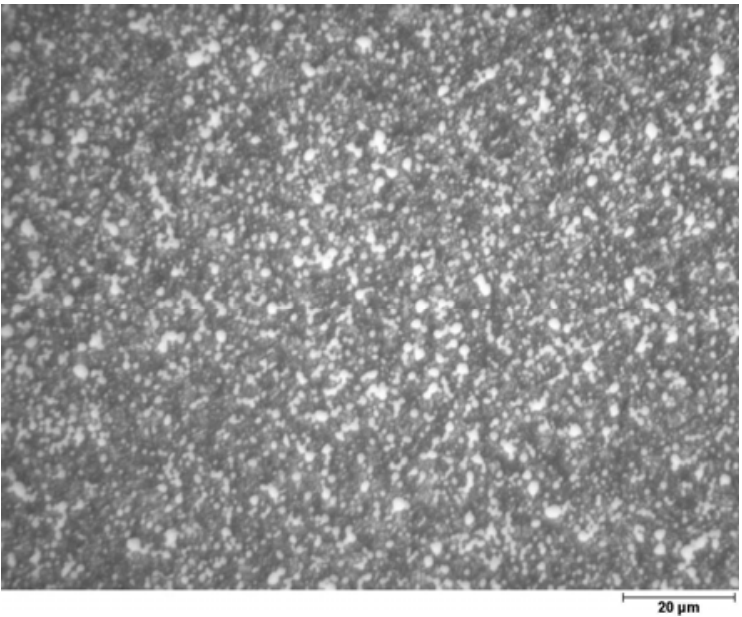

(d)

Figura 53: Secção transversal do aço Vanadis 10. (a) somente temperado; (b) temperado e revenido a $430^{\circ} \mathrm{C}$; (c) temperado e revenido a $525^{\circ} \mathrm{C}$; (d) temperado e revenido a $550^{\circ} \mathrm{C}$.

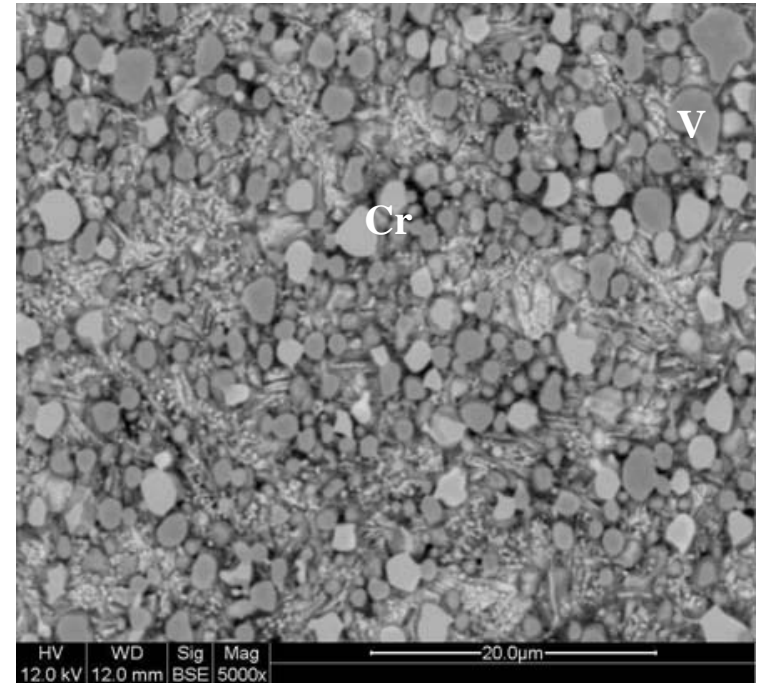

(a)

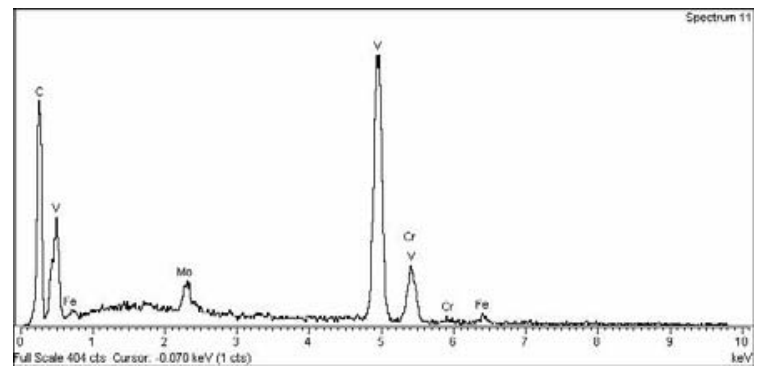

(c)

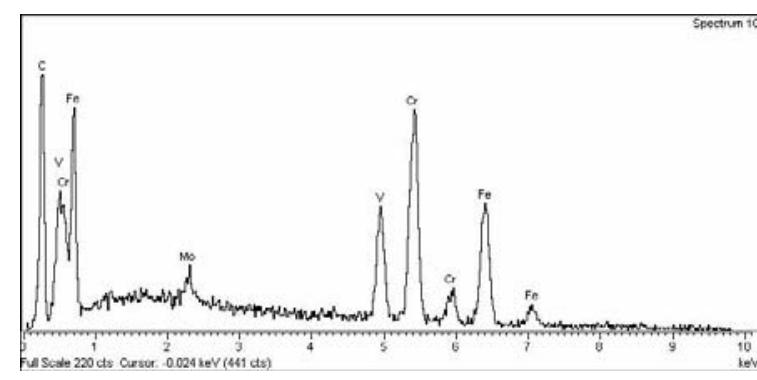

(b)

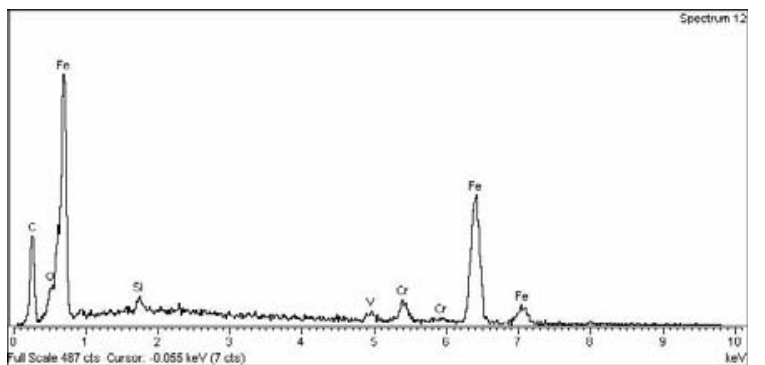

(d)

Figura 54: (a) Secção transversal do aço Vanadis 10 somente temperado. Ataque Marble; (b) EDS carbonetos (claros) ricos em cromo, possivelmente do tipo $M_{7} C_{3}$; (c) EDS carbonetos ricos em vanádio, possivelmente do tipo $\mathrm{M}_{2} \mathrm{C}$; (d) EDS da matriz.

$\mathrm{Na}$ figura 54a está apresentada a secção transversal do aço Vanadis 10 temperado. Observa-se a matriz martensítica e a presença de precipitados ricos em $\mathrm{Cr}$ 
(claro), provavelmente do tipo $\mathrm{M}_{7} \mathrm{C}_{3}$ e ricos em $\mathrm{V}$ (escuro), provavelmente do tipo MC. As figuras 55b-d são o mesmo aço na condição temperado e revenido.

$\mathrm{Na}$ figura 55a está apresentada a microestrutura do aço Vanadis 10 temperado e revenido. Observa-se a matriz de martensita revenida e precipitados ricos em $\mathrm{Cr}$ (claros) e $\mathrm{V}$ (escuros), este último provavelmente do tipo MC. As figuras 55b-c são medidas de EDS dos carbonetos. A figura 55d é o EDS da matriz. O efeito da temperatura de revenimento na precipitação dos carbonetos pode ser notada no endurecimento secundário deste aço, próximo à temperatura de $525^{\circ} \mathrm{C}$. A maior precipitação dos carbonetos tipo $\mathrm{MC}-\mathrm{M}_{4} \mathrm{C}_{3}$ (rico em vanádio), deve ocorrer em temperatura acima da temperatura em que precipitam carbonetos do tipo $\mathrm{M}_{2} \mathrm{C}$, ricos em molibdênio.

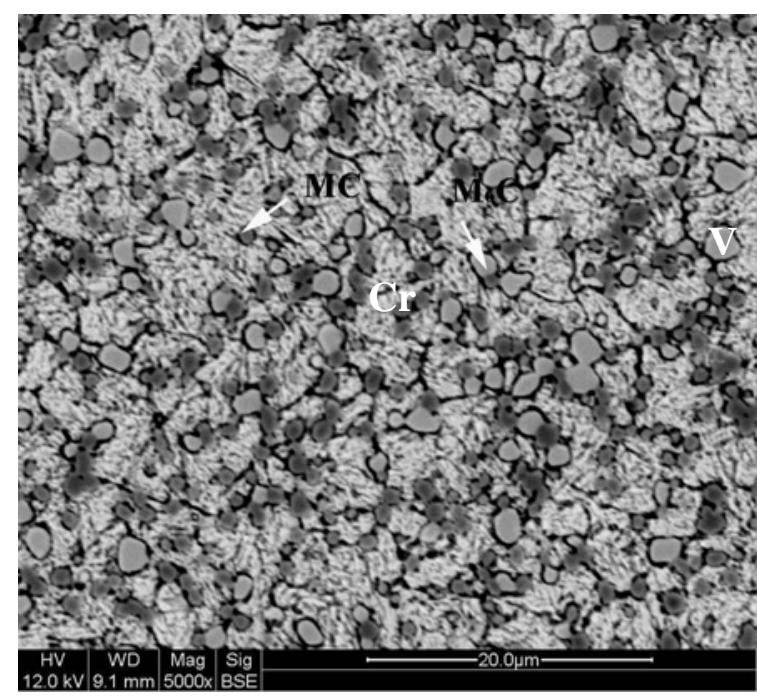

(a)

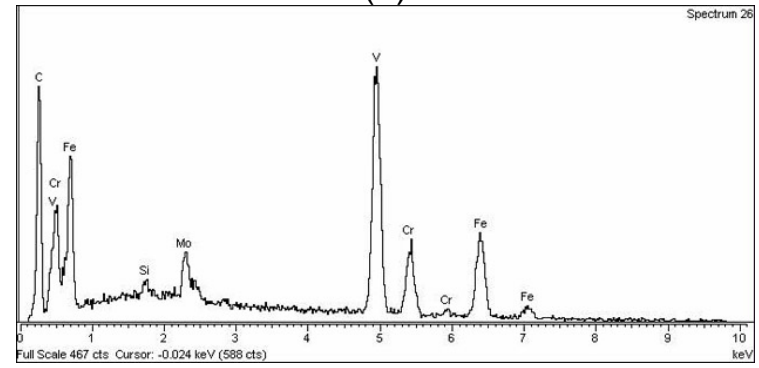

(c)

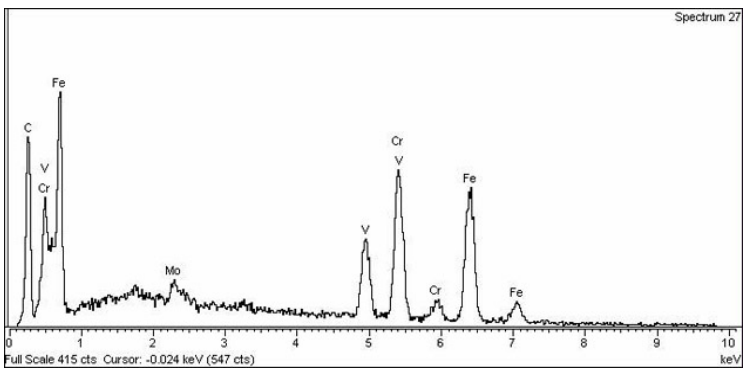

(b)

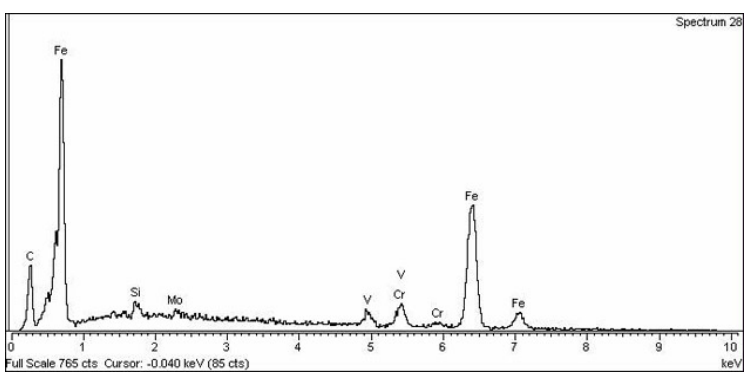

(d)

Figura 55: (a) Seção transversal do aço Vanadis 10 temperado e revenido a $430^{\circ} \mathrm{C}$. Ataque Nital 3\%; (b) EDS dos carbonetos primários; (c) EDS dos carbonetos secundários; (d) EDS da matriz.

Observou-se que a dureza indicada pela curva do fabricante apresenta maior desvio em relação à curva de dureza obtida nos tratamentos térmicos realizados. Os revenimentos a $430^{\circ} \mathrm{C}(61,9 \sim 64 \mathrm{HRC})$ e $525^{\circ} \mathrm{C}(61,1 \sim 64 \mathrm{HRC})$ mostraram maior 
dispersão no resultado. Foi observado ainda que a dureza decresce com o aumento da temperatura de revenimento, porém apresenta pico de endurecimento secundário em $525^{\circ} \mathrm{C}(61,1 \mathrm{HRC})$, devido à precipitação de carbonetos complexos. O limite de resistência apresenta um máximo à $430^{\circ} \mathrm{C}(61,9 \mathrm{HRC})$ e a tenacidade varia em relação à dureza, apresentando melhores índices nas temperaturas de $430^{\circ} \mathrm{C}$ e $525^{\circ} \mathrm{C}(61,1 \mathrm{HRC})$. A resistência à carga máxima de flexão (módulo de ruptura) varia em relação à dureza, apresentando bons índices em $430^{\circ} \mathrm{C}$ e $550^{\circ} \mathrm{C}(60,3 \mathrm{HRC})$.

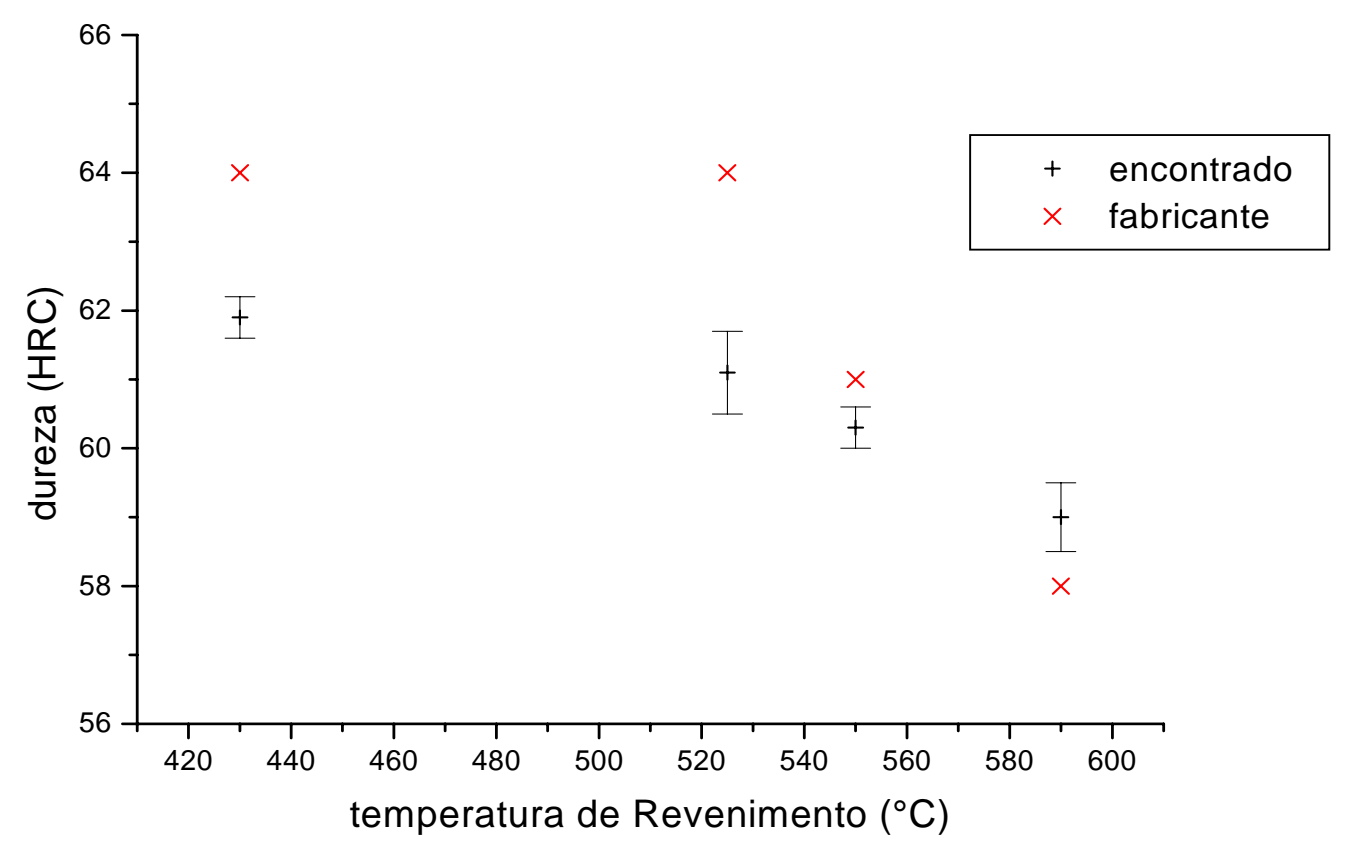

Figura 56: Dureza em função da temperatura de revenimento para o aço Vanadis 10. 


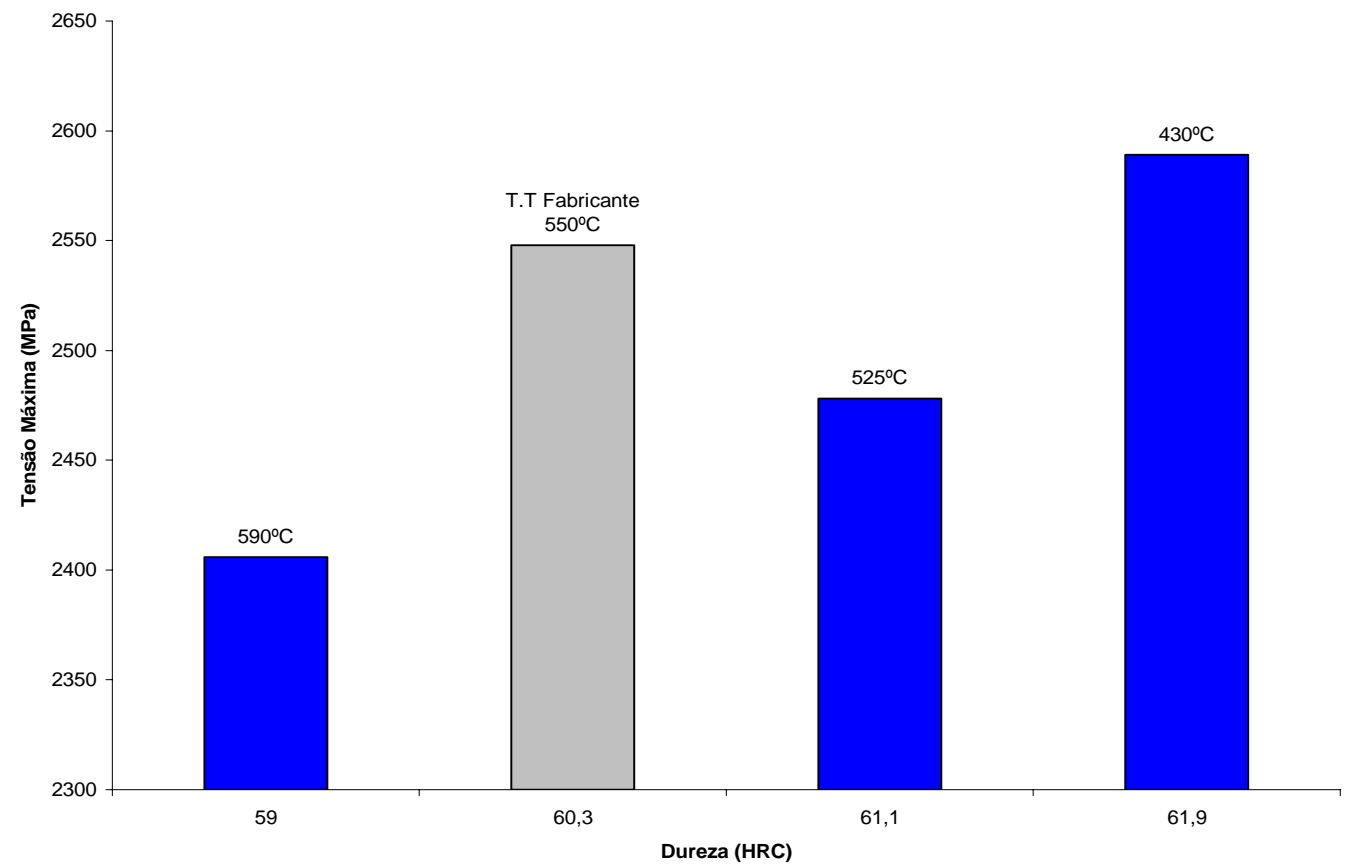

Figura 57: Limite de resistência em função da dureza para o aço Vanadis 10.

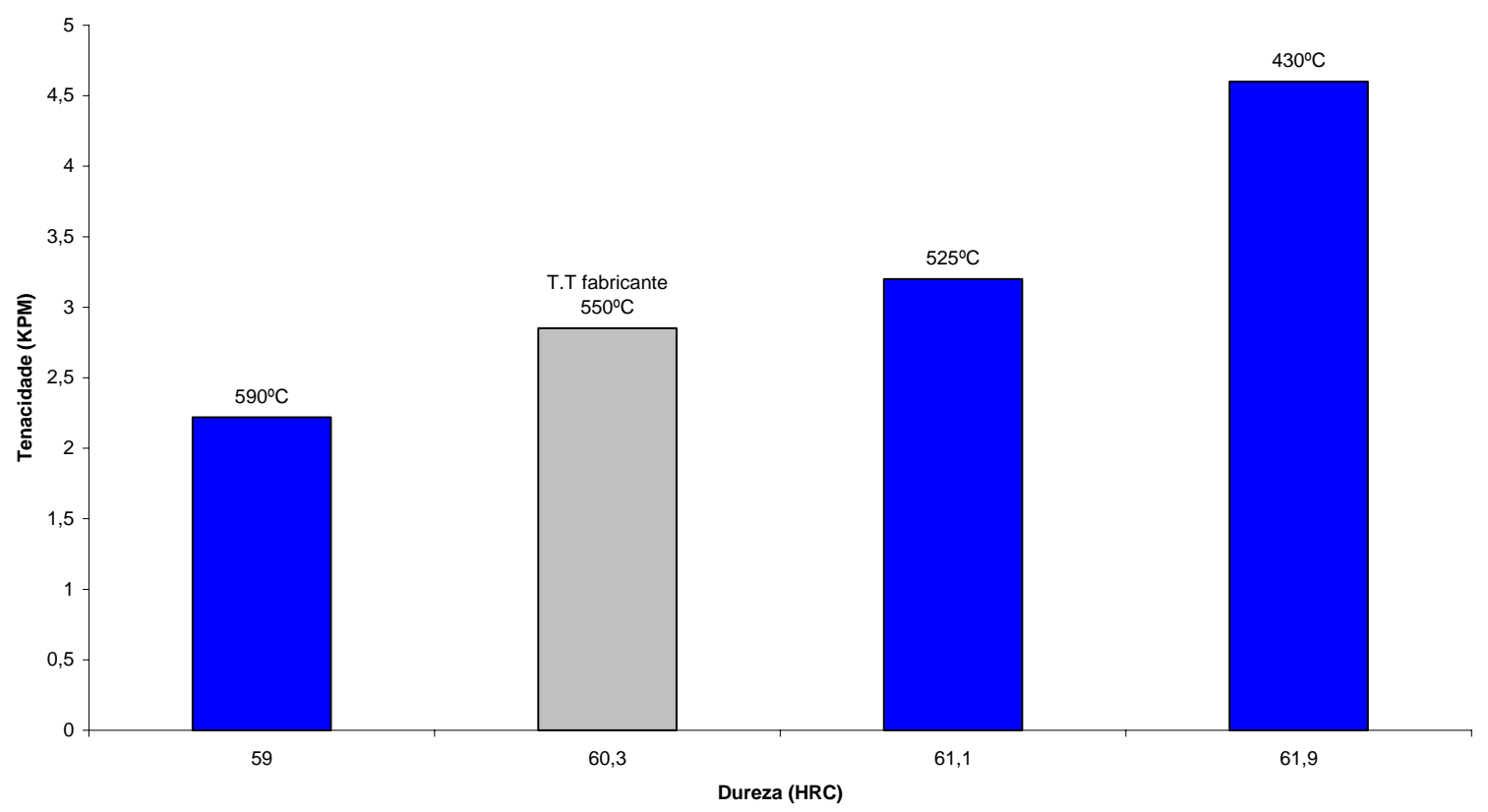

Figura 58: Tenacidade à fratura em função da dureza para o aço Vanadis 10. 


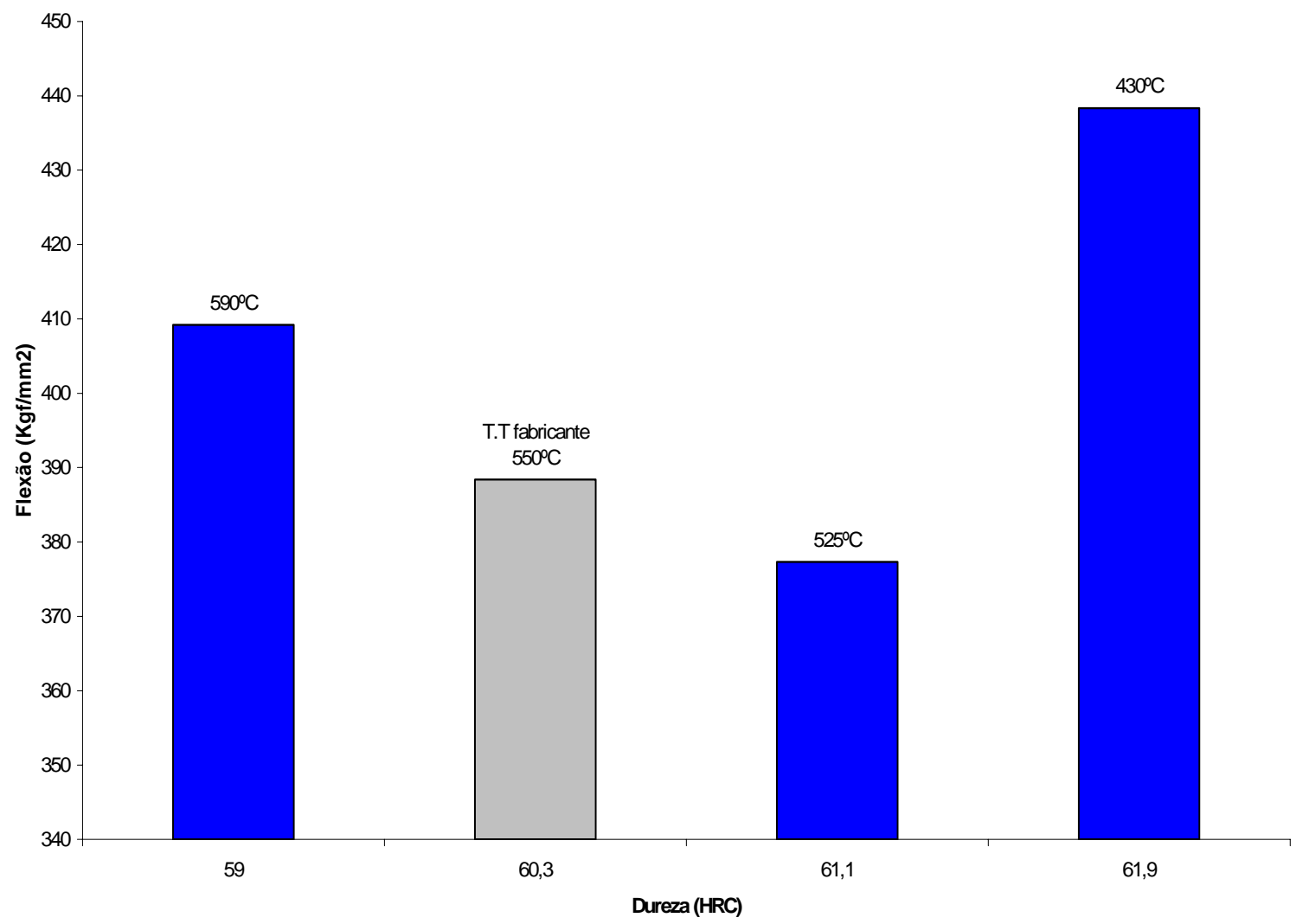

Figura 59: Módulo de ruptura em função da dureza para o aço Vanadis 10.

As superfícies típicas de relevo de fratura são mostradas nas figuras 60 e 61 , vistas em imagem de elétrons secundários (MEV). Estas análises fractográficas realizadas em corpos de prova ensaiados por impacto Charpy sem entalhe indicaram aspecto representativo de quasi-clivagem, o mesmo aspecto de fratura que ocorreu para os diferentes materiais, em diferentes condições de revenimento [46,47]. Este aspecto de fratura é típico em microestruturas compostas de grande fração volumétrica de partículas frágeis em uma matriz de martensita revenida.

As análises de fratura e as características observadas nos corpos de prova mostraram que para diferentes regiões e direções observadas, o mecanismo não se alterou, confirmando o aspecto da isotropia deste aço. É importante lembrar que o mecanismo envolvido nas fraturas observadas é similar ao do ensaio de flexão 4-pontos, apesar deste apresentar caráter estático, enquanto que o ensaio de impacto Charpy sem entalhe, caráter dinâmico. 


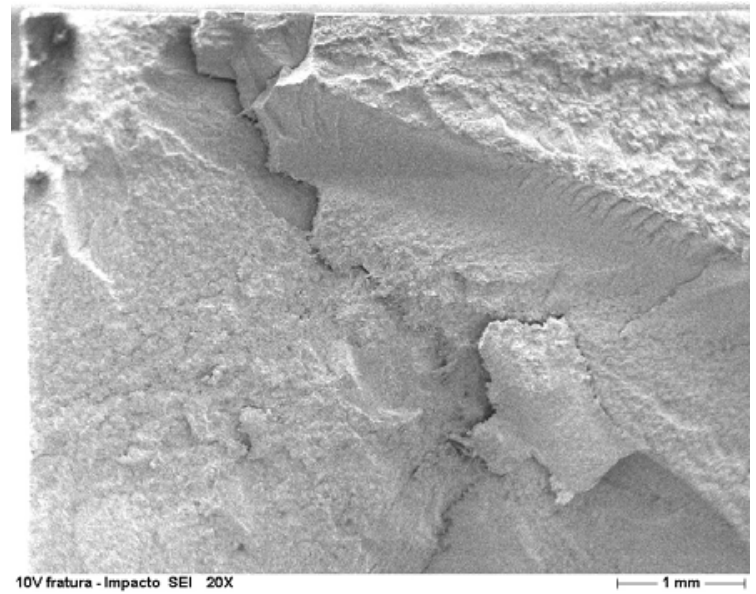

(a)

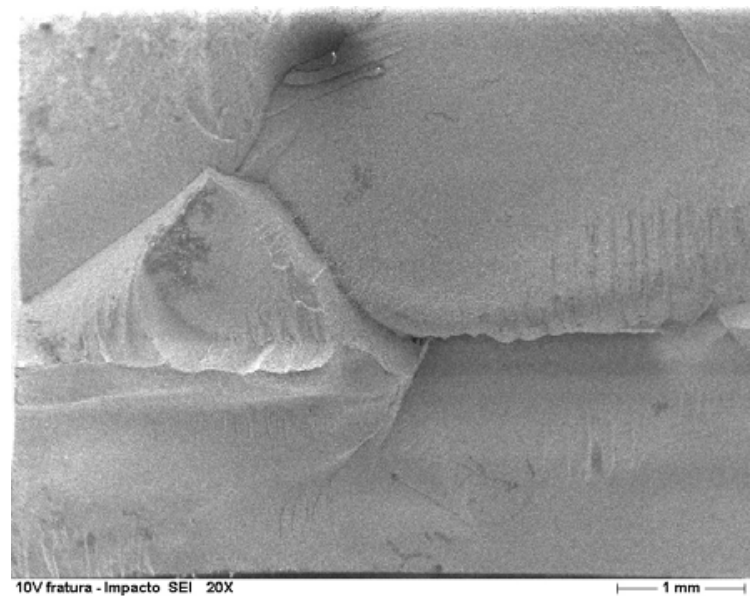

(c)

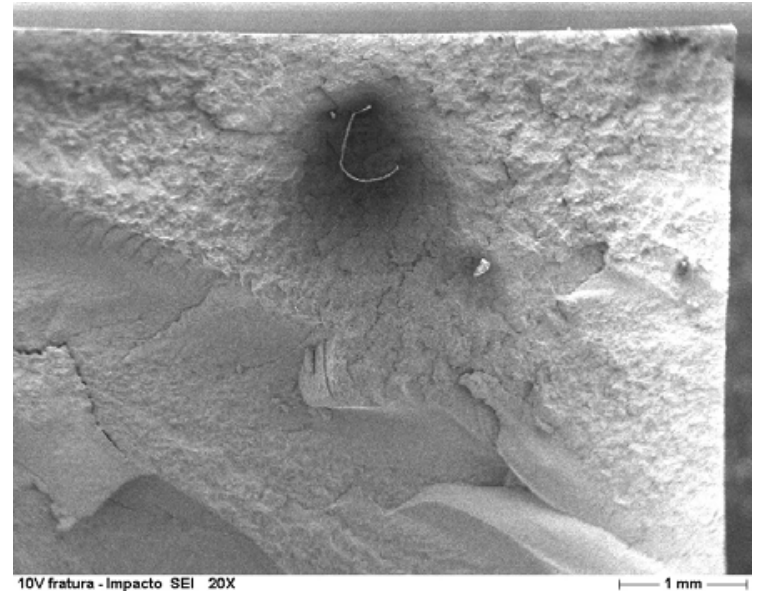

(b)

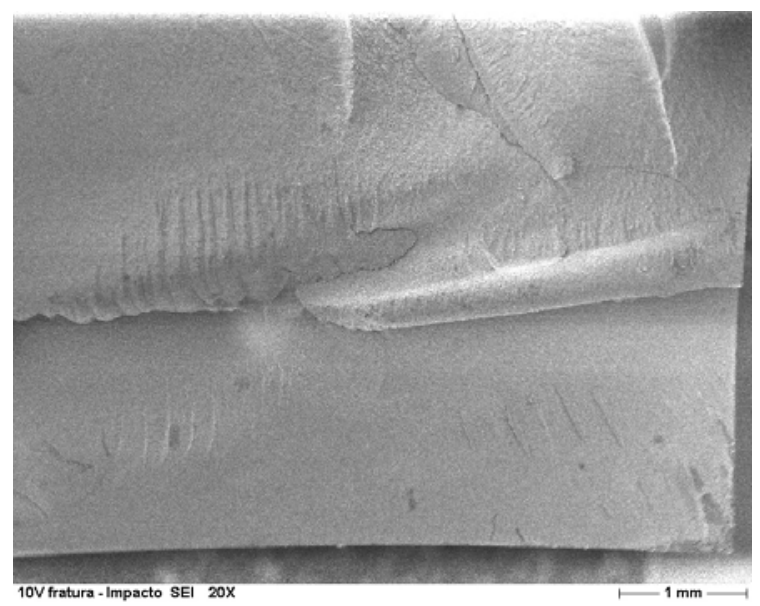

(d)

Figura 60: Vanadis 10: Fractografia típica, mostrando a superfície de fratura do corpo-deprova.

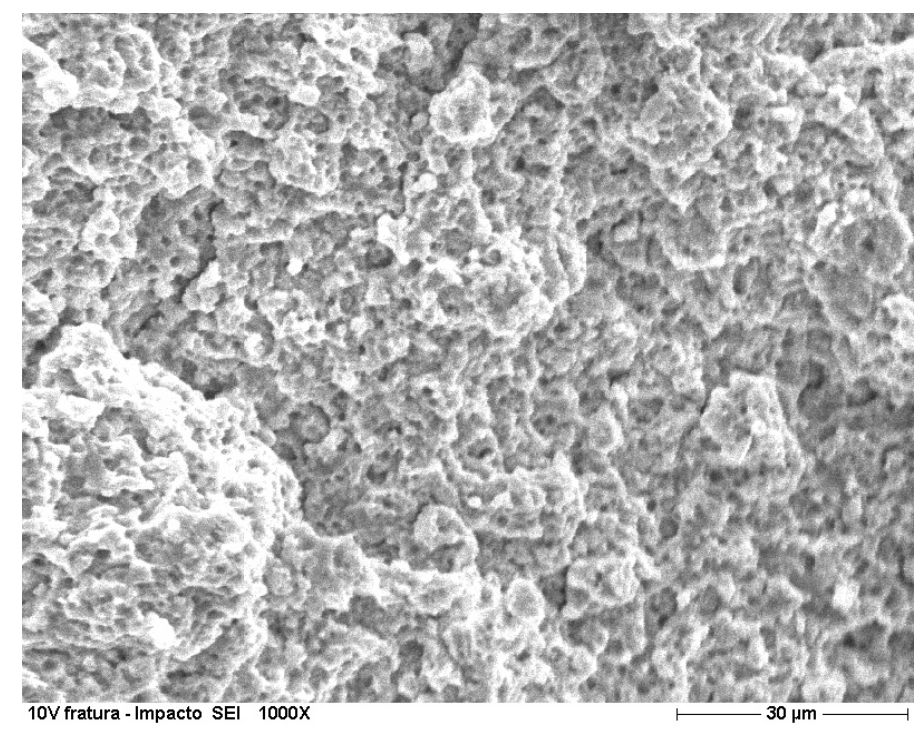

Figura 61: Vanadis 10: Detalhe da figura anterior, mostrando a região próxima à borda. Região de provável início da fratura. 
A recomendação do fabricante para temperatura de revenimento de aproximadamente $550^{\circ} \mathrm{C}$ (60,3 HRC) não está completamente de acordo com os resultados obtidos neste estudo, pois o aço Vanadis 10 apresentou melhor desempenho quando revenido na temperatura de $430^{\circ} \mathrm{C}$;

\subsection{Comentários Gerais}

As modernas técnicas para fabricação de aços-ferramenta possibilitaram novas metodologias para o desenvolvimento de projetos de ligas com expressiva elevação da fração volumétrica de partículas duras. O aço-ferramenta para trabalho a frio, com altos teores de carbono, cromo, molibdênio e vanádio, se revela como um exemplo típico deste novo conceito de projeto de ligas, que encontraram viabilidade de produção e de aplicação após serem submetidas a novas técnicas de tratamento térmico, resultando em uma microestrutura mais fina e homogênea.

As ligas citadas neste estudo são somente exemplos do avanço que a produção de aços de alta resistência pode ter, mesmo sendo processadas com a técnica de fundição tradicional de produção de aços-ferramentas com o intuito de envolver a segregação do carbono em defeitos do reticulado, a precipitação de carbonetos, a decomposição da austenita retida e a recuperação e recristalização da estrutura martensítica.

As análises microestruturais do presente estudo revelaram, no geral, precipitados mais finos otimizando a tenacidade. A presença de carbonetos de elevada dureza, responsáveis pelo incremento das propriedades ligadas à alta resistência ao desgaste, aparecem na microestrutura com importante participação, devido ao revenimento em várias temperaturas.

Contudo, a preocupação com a tenacidade da microestrutura da liga prosseguiu no presente trabalho, buscando-se respostas em função de ensaios mecânicos e análises microestruturais.

A preocupação excessiva com a resistência ao desgaste de um aço-ferramenta para trabalho a frio, procurando alta dureza, pode prejudicar a tenacidade do mesmo. Para se equilibrar este efeito, procura-se alguns fenômenos metalúrgicos, como precipitação de carbonetos finos e remoção da fração de austenita retida, obtendo-se maior tenacidade.

Os aços-ferramenta tradicionais, como os AISI D6 e AISI D2, após têmpera, são comumente revenidos e apenas atingem a dureza necessária através de grosserios carbonetos ricos em cromo dos tipos $\mathrm{M}_{3} \mathrm{C}$ e $\mathrm{M}_{7} \mathrm{C}_{3}$, derivados da cementita. Por outro lado, 
as curvas de revenimento dos aços utilizados para comparação, temperados a partir de $800^{\circ} \mathrm{C}$, mostram a possibilidade de obtenção da dureza de até $62 \mathrm{HRC}$, após revenimento em até duas temperaturas, com provável precipitação de carbonetos mais complexos dos tipos $\mathrm{M}_{2} \mathrm{C}, \mathrm{M}_{7} \mathrm{C}_{3}, \mathrm{M}_{23} \mathrm{C}_{6}$ e $\mathrm{MC}$. $\mathrm{O}$ duplo ou triplo revenimento geralmente é aplicado nestes aços-ferramenta para promover o endurecimento secundário consistente com finos carbonetos, para transformar a austenita retida em martensita, e também para revenir esta martensita não revenida, formada depois do primeiro revenimento [5,31].

A dureza similar à dos aços AISI D2 e AISI D6 com melhores propriedades mecânicas, se deve ao fato de que os aços-ferramenta para trabalho a frio alto $C$ - alto $\mathrm{Cr}, \mathrm{Mo}, \mathrm{V}$, a partir da faixa de $500^{\circ} \mathrm{C}$, apresentam a referida quarta etapa do revenido (endurecimento secundário), que retarda a queda das propriedades mecânicas. Portanto, uma reação de endurecimento secundário mais intensa pode ocorrer em altas temperaturas de revenimento, onde o cromo, o molibdênio e o vanádio são capazes de difundir e podem precipitar carbonetos finos de liga. Algumas aplicações ferramentas para trabalho a frio podem se beneficiar com o estudo do tratamento térmico com ênfase na tenacidade de aços de alta resistência ao desgaste.

A precipitação de carbonetos durante o revenimento aumenta a dureza e a resistência mecânica dos aços-ferramenta, e esse fenômeno, como já citado anteriormente, é conhecido como "endurecimento secundário". Isso ocorre nos aços VF800 e Vanadis 10 devido à presença dos elementos cromo, molibdênio e vanádio em teores adequados. Depois que a dureza passa por um pico, a transição $M C / M_{2} C$ para $\mathrm{M}_{7} \mathrm{C}_{3} / \mathrm{M}_{23} \mathrm{C}_{6}$ ricos em cromo, bem como o coalescimento das partículas em geral pode ocorrer, levando novamente a uma perda de dureza no aço[12].

Alguns elementos não formadores de carbonetos presentes na liga como o silício, níquel e cobalto não produzem endurecimento secundário, porém pode aumentar a dureza por solução sólida e podem atrasar as reações de revenido promovendo maior resistência em temperaturas inferiores a de endurecimento secundário [12,24,29].

Nos aços ao cromo, por exemplo, dois tipos de carbonetos podem ser encontrados: $\mathrm{Cr}_{7} \mathrm{C}_{6}$ (hexagonal) e $\mathrm{Cr}_{23} \mathrm{C}_{6}$ (cúbico complexo). A seqüência de precipitação é a seguinte [5,24,31]:

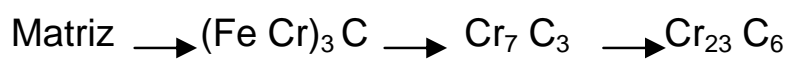

Esta seqüência pode ocorrer em aços com mais de 7\% de cromo. Abaixo deste teor o $\mathrm{Cr}_{23} \mathrm{C}_{6}$ pode não ser encontrado, a menos que o molibdênio esteja presente. 
Como o Mo é um elemento de liga presente nos aços em estudo, com teor médio de $1 \%$, pode se formar precipitados intermediários como $\mathrm{M}_{23} \mathrm{C}_{6}$ e $\mathrm{Fe}_{2} \mathrm{MC}$ entre as fases $M_{2} C$ e $M_{6} C$. A sequencia mais provável de precipitação do elemento Mo é a seguinte:

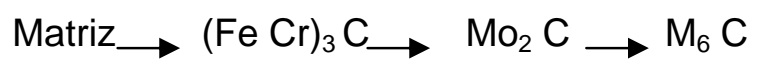

Tanto o molibdênio quanto o tungstênio promovem esta sequência de precipitação, mas a presença do elemento molibdênio nos aços-ferramenta traz benefícios em relação ao elemento tungstênio, pois além de promover uma precipitação em temperaturas mais baixas, promove um eutético mais fino, com carbonetos menores, mas bem distribuídos, e com austenita retida menos estável, podendo também reduzir a velocidade de coalescimento do MC $[8,12,24]$.

O vanádio, presente em alto teor na liga Vanadis 10, promove o endurecimento secundário com a precipitação do carboneto de maior dureza $-\mathrm{MC}$, sendo $\mathrm{M}_{4} \mathrm{C}_{3} \mathrm{a}$ composição estequiométrica mais próxima. A presença do vanádio também tende a estabilizar o $\mathrm{Cr}_{7} \mathrm{C}_{3}[31,36]$.

O cromo difunde-se na ferrita mais facilmente que a maioria dos outros elementos metálicos e por isso o endurecimento secundário pode ser notado em temperaturas relativamente mais baixas $\left(400^{\circ} \mathrm{C}\right)[31]$. 


\section{CONCLUSÕES}

1) A recomendação do fabricante para temperatura de revenimento de $300^{\circ} \mathrm{C}(57,2 \mathrm{HRC})$ para o aço VND está de acordo com os resultados obtidos neste estudo, para explorar um campo intermediário do material, equilibrando suas propriedades sem levar em consideração aplicações específicas, onde poderia exigir mais tenacidade ou mais resistência do aço. Entretanto, para este aço existe a possibilidade de se trabalhar com nível de dureza um pouco superior ao recomendado pelo fabricante $\left(260^{\circ} \mathrm{C}-58,9 \mathrm{HRC}\right)$, com sensível melhora nos parâmetros de resistência sem, no entanto, a ocorrência de um decréscimo importante em termos de tenacidade medida pelo ensaio de impacto Charpy.

2) A recomendação do fabricante para temperatura de revenimento $250^{\circ} \mathrm{C}(57,5 \mathrm{HRC})$ para o aço Calmax não está totalmente de acordo com os resultados obtidos neste estudo. As temperaturas de revenimento $300^{\circ} \mathrm{C}$ e $350^{\circ} \mathrm{C}( \pm 55 \mathrm{HRC})$ mostram grandes índices em tenacidade e resistência, apesar de apresentar menor dureza. É possível trabalhar com dureza um pouco inferior ao recomendado pelo fabricante, com significativa melhora nos parâmetros de tenacidade, sem a ocorrência de um decréscimo na tensão medida pelos ensaios de tração e flexão.

3) A recomendação do fabricante para temperatura de revenimento de aproximadamente $550^{\circ} \mathrm{C}$ (59,5HRC) par o aço VF-800 não está completamente de acordo com os resultados obtidos neste estudo, pois a temperatura de revenimento de $475^{\circ} \mathrm{C}(61,4 \mathrm{HRC})$ mostra bons índices de desempenho do material. A elevada dureza atingida no revenimento a $475^{\circ} \mathrm{C}$ está associada ao melhor desempenho em todos os ensaios, com particular atenção aos resultados de energia absorvida em ensaio de impacto charpy, tornando-se, portanto, a melhor condição de tratamento térmico deste material, no que se refere ao equilíbrio entre dureza, resistência à tração e tenacidade.

4) A recomendação do fabricante para temperatura de revenimento de aproximadamente $550^{\circ} \mathrm{C}(60,3 \mathrm{HRC})$ para o aço Vanadis 10 não está completamente de acordo com os 
resultados obtidos neste estudo, pois a temperatura de revenimento de $430^{\circ} \mathrm{C}(61,9 \mathrm{HRC})$ também mostra grandes índices de desempenho do material. Este material segue a linha do que foi apresentado para o aço VF-800, pois a dureza atingida em temperatura de revenimento inferior à recomendada pelo fabricante está associada a um ótimo desempenho em todos os ensaios com particular atenção aos resultados de energia absorvida em ensaio de impacto charpy, tornando-se, portanto, a melhor condição de tratamento térmico deste material no que se refere ao equilíbrio entre dureza, resistência à tração e tenacidade. 


\section{REFERÊNCIAS BIBLIOGRÁFICAS}

1 MURAKAMI, Y.; KODAMA, S.; KONUMA, S. Quantitative evaluation of the effects of non-metallic inclusions on fatigue strength of high strength steels. I: Basic fatigue mechanism and evaluation of correlation between the fatigue fracture stress and the size and location of non-metallic inclusions. International Journal of Fatigue, (1989), 291-298.

2 MEURLING, F.; MELANDER, A.; LINDER, J.; LARSSON, M. Effect of cutting method on the fatigue strength of high strength sheet steels. In: Bache, M.R.; Blackmore, P.A.; Draper, J.; Edwards, J.H.; Roberts, P.; Yates, J.R., Ed. Fatigue 2000 - Fatigue and durability assessment of materials, components and structures. UK, 2000, 495-506.

3 MEURLING, F.; MELANDER, A.; TIDESTEN, M. WESTIN, L. Influence of carbide and inclusion contents on the fatigue properties of high speed steels and tool steels. International Journal of Fatigue, 23 (2001), 215-224.

4 COSTA e SILVA, A. L.; MEI, P. R. Aços e Ligas Especiais. 2. ed., 1988.

5 ROBERTS, G.; KRAUSS, G.; KENNEDY, R. Tool Steels. 5. ed., American Society for Metals, Metals Park, OH., 1998.

6 American Society For Metals - Metals Handbook. v. 1, 7. ed., 1983.

7 LAKHTIN, Y. Engineering Physical Metallurgy. 2. ed., Moscou: MIR Publishers, 1972.

8 HOYLE, G. High Speed Steels. Cambridge, Ingl.: Butterworths, 1998.

9 AVNER, S. H. Introduction to Physical Metallurgy. 2. ed., McGraw-Hill, 1974.

10 VATAVUK, J. Seleção de aços-ferramenta - Introdução a Metalurgia Física e Natureza Cristalina dos Metais - Apostila do Curso - TMS $-2002$. 
11 KRAUSS, G. Steels: Heat Treatment and Processing Principles. Colorado: ASM International, 2st ed., 1990

12 KRAUSS G. Principles of Heat Treatment of Steel. Ohio, A. Society for metals, 1980

13 TOOL STEELS. Steel Products Manual. Iron and Steel Society. 1998.

14 MADDIN, R. A History of Martensite: Some thoughts of the early hardening of iron. Martensite. ASM International, GB. Olson and W. S. Owen, p. 11-19, 1992

15 AÇOS BÖHLER - Catálogo Técnico - 2002.

16 UDDEHOLM - Catálogos Técnicos - Aços Especiais - 2002 - 2006.

17 CRUCIBLE PARTICLE METALLURGY - Technical Catalogue Crucible Tool Steel and Specialty Alloy Selector, 2001.

18 TYSSEN - Catálogo Técnico - Aços Especiais Brasil, 1. ed., nov., 1998

19 Relatórios MAHLE METAL LEVE - Centro de Pesquisas Tecnológicas 2002 a 2006.

20 WILSON, R. Metallurgy and Heat Treatment of Tool Steels. London, N. Y.: McGraw-Hill, 1975.

21 AÇOS VILLARES - Catálogos Técnicos - Aços para trabalho a frio 2002-2006

22 EBNER, R.; LEITNER, H.; JEGLITSCH, F.; CALISKANOGLU, D. Methods of property oriented tool steel design. In: $5^{\text {th }}$ INTERNATIONAL CONFERENCE ON TOOLING, Sept. 29 - Oct. 01, 1999, Leoben. Proceedings, Leoben, 1999. p. 03-24.

23 LESLEI, W. C. The Physical Metallurgy of Steels. McGraw-Hill, 1982.

24 HONEYCOMBE, R. M. K. Steels - Microstructure and Properties. Edward Arnold, 1981.

25 REED-HILL, R. E. Physical Metallurgy Principles. 2. ed., London: N.Y.: Van Nostrand Reinhold, 1973.

26 MONTEIRO, W. A.; BUSO, S. J. Caracterização de materiais por métodos físicos. (Apostila de curso) Técnicas de microscopia 
eletrônica aplicada a materiais de interesse nuclear. Pósgraduação - Instituto de Pesquisas Energéticas e Nucleares, USP, 2005.

27 BROOKS, C. R. Principle of Austenitization of Steels. England: Elsevier Science Publishers, 1992.

28 SPEICH, G. R.; LESLEI, W. C. Tempering of Steel. Metallurgical Transactions, v. 3, p. 1043-1054, 1972.

29 TSCHIPTSCHIN, A. P.; GOLDSTEIN, H.; SINÁTORA, A. Metalografia dos aços. Associação Brasileira de Metais, 1988.

30 PAYSON, P.; SAVAGE, C. H. Martensite Reactions in Alloy Steels. Transactions of the ASM, v. 33, p. 261-275, 1944.

31 KUO, K. Alloy Carbides Precipitated During the Fourth Stage of Tempering. Journal of Iron and Steel Institute, Nov., p. 256-258, 1956.

32 HONG, S.-H.; BAE, J.-S.; KJM, Y.-J. Effects of inclusions and tempering temperature on the life of a powder compacting punch. Engineering Failure Analysis, 10 (2003), 237-243.

33 PORTER, D. A.; EASTERLING, K. E. Phase Transformation in Metals and Alloys. Van Nostrand Reinhold, 1987.

34 HUTCHINGS, I. M. Tribology: Friction and Wear of Engineering Materials. Edward Arnold, 1992.

35 GRINDER, O. PM HSS and tool steels - present state of the art and development trends. In: $5^{\text {th }}$ INTERNATIONAL CONFERENCE ON TOOLING, Sept. 29 - Oct. 01, 1999, Leoben. Proceedings, Leoben, 1999. p. 39-48.

36 JESPERSON, H. Toughness of Tool Steels. Proceeding of: $5^{\text {th }}$ INTERNATIONAL CONFERENCE ON TOOLING, Sept. 29 - Oct. 01, 1999, Leoben. Proceedings, Leoben, 1999. p. 93-102.

37 Standard Test Methods for Notched Bar Impact Testing of Metallic Materials - E23-06 - Copyright 2006 ASTM International.

38 Standard Test Methods for Tension Testing of Metallic Materials - E8M04 - Copyright 2006 ASTM International 
39 Standard Test Method for Transverse Testing - A438-80 - Copyright 2006 ASTM International

40 SOUZA, S. A. Ensaios mecânicos de Materiais Metálicos. 1. ed. São Paulo: Edgard Blücher, 1995.

41 AMERICAN SOCIETY FOR TESTING AND MATERIALS. Standard Test Method and Definitions for Mechanical Testing of Steel Products. Mar. 10, 1997. (ASTM A 370 - 97a). In: ANNUAL Book of ASTM Standards. Section 1: Steel - Structural, Reinforcing, Pressure Vessel, Railway. v. 01.04. p. 235-277.

42 SOARES, E. Avaliação das Propriedades Mecânicas e da Microestrutura de um Aço para Trabalho a Frio Produzido por Metalurgia Convencional. Anais: $3^{\circ}$ CONFERENCIA BRASILEIRA SOBRE TEMAS DE TRATAMENTO TÉRMICO, Junho $20-23$. 2006.

43 SOARES, E. Evaluation of Mechanical Properties and Microstructure of Tool Steel Produced by Powder Metallurgy. Proceeding of: FIFTH INTERNATIONAL LATIN-AMERINCA CONFERENCE ON POWDER TECHNOLOGY, October 26-29. 2005 - Brazil.

44 Standard Test Method for Brinell Hardness of Metallic Materials - E1001e1 - Copyright 2006 ASTM International

45 Standard Test Methods for Rockwell Hardness and Rockwell Superficial Hardness of Metallic Materials - E18-05e1 - Copyright 2006 ASTM International

46 PANELLI, R. Comunicação pessoal. (renatopanelli@uol.com.br)

47 VATAVUK, J. Comunicação pessoal. (janvatavuk@uol.com.br) 